UNIVERSIDADE FEDERAL DE JUIZ DE FORA

INSTITUTO DE CIÊNCIAS BIOLÓGICAS

PÓS GRADUAÇÃO EM CIÊNCIAS BIOLÓGICAS - IMUNOLOGIA E DOENÇAS INFECTO-PARASITÁRIAS/ GENÉTICA E BIOTECNOLOGIA

Suzane Fernandes da Silva

Resistoma clínico intestinal de indivíduos onívoros, ovolactovegetarianos e vegetarianos estritos

Juiz de Fora 
Suzane Fernandes da Silva

Resistoma clínico intestinal de indivíduos onívoros, ovolactovegetarianos e vegetarianos estritos

\author{
Dissertação apresentada ao Programa de \\ Pós-graduação em Ciências Biológicas - \\ Imunologia e Doenças Infecto-parasitárias/ \\ Genética e Biotecnologia da Universidade \\ Federal de Juiz de Fora como requisito \\ parcial à obtenção do título de mestre em \\ Ciências Biológicas. Área de concentração: \\ Imunologia e Doenças Infecto-parasitárias.
}

Orientador: Prof. Dr. Cláudio Galuppo Diniz

Coorientadores: Prof ${ }^{a}$ Dra $^{a}$ Vânia Lúcia da Silva Prof $^{a}$ Dra $^{a}$ Alessandra Barbosa Ferreira Machado

Juiz de Fora 
Ficha catalográfica elaborada através do programa de geração automática da Biblioteca Universitária da UFJF, com os dados fornecidos pelo(a) autor(a)

Fernandes da Silva, Suzane.

Resistoma clínico intestinal de indivíduos onívoros, ovolactovegetarianos e vegetarianos estritos. / Suzane Fernandes da Silva. - 2021.

$120 \mathrm{f}$.

Orientador: Cláudio Galuppo Diniz

Coorientadores: Vânia Lúcia da Silva, Alessandra Barbosa Ferreira Machado

Dissertação (mestrado acadêmico) - Universidade Federal de Juiz de Fora, Instituto de Ciências Biológicas. Programa de

Pós-Graduação em Ciências Biológicas: Imunologia e Genética, 2021.

1. Microbiologia. 2. Resistoma clínico. 3. Microbiota intestinal humana. 4. Hábitos alimentares. I. Galuppo Diniz, Cláudio, orient. II. da Silva, Vânia Lúcia, coorient. III. Barbosa Ferreira Machado, Alessandra, coorient. IV. Título. 


\section{Resistoma clínico intestinal de indivíduos onívoros, ovolactovegetarianos e} vegetarianos estritos

Dissertação apresentada ao Programa de Pós-graduação em Ciências Biológicas Imunologia e Doenças Infecto-parasitárias/ Genética e Biotecnologia da Universidade Federal de Juiz de Fora como requisito parcial à obtenção do título de mestre em Ciências Biológicas. Área de concentração: Imunologia e Doenças Infecto-parasitárias

Aprovada em:

BANCA EXAMINADORA

Prof. Dr. Cláudio Galuppo Diniz - Orientador

Universidade Federal de Juiz de Fora

Prof $^{a}$. Dra ${ }^{a}$. Vânia Lúcia da Silva

Universidade Federal de Juiz de Fora

Profa. Dra ${ }^{a}$. Alessandra Barbosa Ferreira Machado

Universidade Federal de Juiz de Fora

Profa $^{a}$. Dra. Vanessa Cordeiro Dias

Universidade Federal de Juiz de Fora

Prof $^{a}$. Dra . Elisabeth Neumann

Universidade Federal de Minas Gerais 


\section{AGRADECIMENTOS}

Agradeço primeiramente a Deus, por me permitir realizar mais essa etapa em minha vida;

Aos meus pais, Sônia e Sérgio, por serem meu suporte, pelo incentivo diário e por terem paciência para me aguentar enquanto tentava conciliar trabalho e estudos sem surtar;

À minha irmã Sheila, por torcer por mim e sempre me incentivar, mesmo estando longe;

Ao meu orientador e co-orientadores, Cláudio, Vânia e Alessandra, por todos os ensinamentos e conhecimentos compartilhados, e por toparem me orientar, mesmo com a rotina tumultuada que tive durante uma boa parte do mestrado;

À professora Vanessa, pela ajuda de sempre e por todo o carinho por mim durante a realização do mestrado;

Ao professor Thiago, pelo incentivo desde a época que ainda era aluna de iniciação científica e pelas boas conversas durante as suas visitas ao laboratório;

À professora Julliane, por ter me ensinado e me ajudado tanto quando comecei os experimentos;

Aos colegas do laboratório CEMIC/ ICB da UFJF, pela colaboração e rotina agradável;

À Isabela e à Thelma, pela parceria durante o mestrado e por tornarem nossa jornada de trabalho muito mais prazerosa e com bastante café;

À Melina, pela ajuda durante o recrutamento e avaliação nutricional dos voluntários;

Aos colegas da equipe do laboratório de diagnóstico molecular do COVID-19, que me trouxeram uma rotina mais leve durante esses tempos difíceis de pandemia;

Aos colegas do Laboratório Central da Prefeitura de Juiz de Fora (LACEN JF), durante o tempo que trabalhei lá enquanto fazia mestrado, pelo carinho e por me ajudarem quando eu quebrava a cabeça nas diversas tentativas de conciliar meus horários;

Aos meus amigos de longa data, de Juiz de Fora e de Brasília, por torcerem por mim e me mostrarem como é bonito e importante ter pessoas queridas ao nosso lado durante a caminhada. 


\section{RESUMO}

As atividades humanas têm exercido intensa pressão seletiva nas comunidades microbianas na natureza, o que tem resultado em diferentes níveis de modulação dos diferentes ecossistemas microbianos. Dentre estas atividades, o uso de xenobióticos na produção de alimentos, bem como hábitos alimentares humanos figuram como forças expressivas que contribuem para o fenômeno da resistência bacteriana aos antimicrobianos. É reconhecido o fluxo genético horizontal entre microbiota exógena e microbiota intestinal humana $(\mathrm{MIH})$, tendo os alimentos um importante papel na veiculação microbiana neste contexto. Assim, o objetivo deste estudo foi avaliar aspectos da resistência clínica da MIH entre indivíduos saudáveis com diferentes hábitos alimentares. Três grupos de voluntários com hábitos alimentares diferentes, onívoros (ON), ovolactovegetarianos (VT) e vegetarianos estritos (VG), foram submetidos à avaliação nutricional e antropométrica. A partir do DNA metagenômico obtido de amostras fecais destes indivíduos, foi avaliada, por PCR convencional, a ocorrência de 37 determinantes genéticos relacionados à resistência aos antimicrobianos de importância médica humana, para caracterização do resistoma clínico. A correlação entre os diferentes hábitos alimentares e a ocorrência de genes de resistência aos antimicrobianos (ARG) foi avaliada. Um total de 19 ON, 20 VT e 19 VG foram analisados. Não houve diferenças significativas na ingestão calórica média entre os grupos. A ingestão média de proteína foi significativamente maior em $\mathrm{ON}$ e o consumo de fibras e carboidratos foi maior em VG. Dos ARG pesquisados, 22 foram detectados. Nenhuma relação clara entre dietas e ocorrência de ARG foi observada. Os genes de resistência às tetraciclinas, $\beta$-lactâmicos e grupo MLS (macrolídeos, lincosamidas e estreptograminas) foram os mais frequentes, seguidos pelos genes de resistência às sulfonamidas e aminoglicosídeos. Vegetais e alimentos minimamente processados parecem ser a principal fonte de ARG para a MIH. Embora os hábitos alimentares variem entre os indivíduos, o ambiente e a ampla distribuição de ARG a partir de diferentes atividades humanas chamam atenção para a complexidade do fenômeno de resistência bacteriana aos antimicrobianos e a necessidade de seu manejo no contexto de Saúde Única.

Palavras-chave: Resistoma clínico; microbiota intestinal; hábitos alimentares; onívoros; ovolactovegetarianos; vegetarianos estritos. 


\begin{abstract}
Human activities have exerted an intense selective pressure on microbial communities in nature, which has resulted in different levels of modulation of different microbial ecosystems. Among these activities, the use of xenobiotics in food production, as well as human eating habits, act as an expressive force that contribute to the antimicrobial resistance phenomenon. The horizontal genetic flux between exogenous microbiota and intestinal microbiota is recognized, with food having an important role in microbial transmission in this context. Thus, the objective of this study was to evaluate aspects of the clinical resistance of the human intestinal microbiota among healthy individuals with different eating habits. Three groups of volunteers with different eating habits, omnivorous (ON), ovolactovegetarians (VT) and strict vegetarians (VG), were submitted to nutritional and anthropometric assessment. From the metagenomic DNA obtained from fecal samples of these individuals, the occurrence of 37 genetic markers related to resistance to antimicrobials of human medical importance was evaluated by conventional PCR for the characterization of clinical resistome. The correlation between different eating habits and the occurrence of antimicrobial resistance genes (ARG) was assessed. A total of $19 \mathrm{ON}, 20 \mathrm{VT}$ and $19 \mathrm{VG}$ were analyzed. There were no significant differences in the mean caloric intake between the groups. Mean protein intake was significantly higher in $\mathrm{ON}$ group and fiber and carbohydrate consumption was higher in VG group. From the screened ARG, 22 were detected. No clear relationship between diets and occurrence of ARG was observed. Resistance genes against tetracyclines, $\beta$-lactams and MLS group (macrolides, lincosamides and streptogramins) were the most frequent, followed by resistance genes against sulfonamides and aminoglycosides. Vegetables and minimally processed foods seem to be the main source of ARG for human gut microbiota. Although the eating habits vary among the individuals, the open environment and the widespread ARG from different human activities draws attention to the complexity of the antimicrobial resistance phenomenon and the need for its handling in the One Health context.
\end{abstract}

Keywords: clinical resistome; gut microbiota; eating habits; omnivores; ovolactovegetarians; strict vegetarians. 


\section{LISTA DE FIGURAS}

Figura 1. Fluxograma do delineamento experimental utilizado para estudo da ocorrência de genes de resistência à drogas antimicrobianas no metagenoma intestinal e sua correlação com diferentes hábitos alimentares

Figura 2. Distribuição dos determinantes genéticos de resistência detectados entre os grupos de indivíduos onívoros (ON), ovolactovegetarianos (VT) e vegetarianos estritos (VG)

Figura 3. Distribuição dos determinantes genéticos entre os indivíduos onívoros $(\mathrm{ON})$, ovolactovegetarianos (VT) e vegetarianos estritos (VG) de acordo com a classe dos antimicrobianos alvos dos produtos de expressão destes genes.

Figura 4. Diagrama de Venn mostrando a distribuição dos determinantes genéticos de resistência detectados entre os grupos de indivíduos onívoros (ON), ovolactovegetarianos (VT) e vegetarianos estritos (VG) ............................................. 52

Figura 5. Dendrograma mostrando agrupamento de similaridade das amostras de acordo com a presença/ ausência de ARG. Foi utilizado o coeficiente de Dice de similaridade e o método UPGMA (Unweighted Pair Group Method with Arithmetic Averages). Limiar entre 65 a $70 \%$ de similaridade foi considerado 


\section{LISTA DE TABELAS}

Tabela 1. Oligonucleotídeos iniciadores utilizados, tamanhos dos fragmentos esperados e referências...

Tabela 2. Características antropométricas e nutricionais dos participantes 48 


\section{LISTA DE SIGLAS E ABREVIAÇÕES}

ARG - Antimicrobial resistance genes - Genes de resistência aos antimicrobianos ANVISA - Agência Nacional de Vigilância Sanitária

BAL - Bactérias do ácido-lático

BRICS - Brasil, Rússia, Índia, China e África do Sul

CEMIC - Centro de Estudos em Microbiologia

CESPM - Citrobacter freundii, Enterobacter spp., Serratia marcescens, Providencia stuartii e Morganella morganii

CTI - Centro de Terapia Intensiva

DP - Desvio-padrão

DNA - Deoxyribonucleic Acid - Ácido desoxirribonucleico

ECDC - European Centre for Disease Prevention and Control - Centro Europeu de Prevenção e Controle de Doenças

ESBL - Extended spectrum $\beta$-lactamase - $\beta$-lactamase de espectro estendido

GLASS - Global Antimicrobial Resistance Surveillance System - Sistema Global de Vigilância de Resistência Antimicrobiana

IMC - Índice de massa corporal

IPCS - Infecção primária de corrente sanguínea

$\mathrm{MIH}$ - microbiota intestinal humana

MFS - Major facilitator superfamilily - Superfamília de facilitadores principais

MLS - Macrolídeos, lincosamidas e estreptograminas

MRSA - Methicillin resistant Staphylococcus aureus - Staphylococcus aureus resistente à meticilina

OMS - Organização Mundial de Saúde

ORF - Open Reading Frames

RPP - Ribossomal protection protein - Proteína de proteção ribossomal

PABA - Ácido para-amino benzoico

PBP - Penicillin binding protein - Proteína ligadora de penicilina

PCR - Polymerase chain reaction - Reação em cadeia da polimerase

QQFA - Questionário quantitativo de frequência alimentar 
RDC - Resolução de Diretoria Colegiada

RENAME - Relação Nacional de Medicamentos

TBE - Tris-borato-EDTA

VISA - Vancomycin intermediate Staphylococcus aureus - Staphylococcus aureus com susceptibilidade reduzida à vancomicina

VRE - Vancomycin resistant Enterococcus sp. - Enterococcus sp. resistente à vancomicina

VRSA - Vancomycin resistant Staphylococcus aureus - Staphylococcus aureus resistente à vancomicina 


\section{SUMÁRIO}

1 INTRODUÇÃO

2 REVISÃO DA LITERATURA

2.1 SAÚDE E RESISTÊNCIA AOS ANTIMICROBIANOS

2.2 MECANISMOS DE RESISTÊNCIA ………………........................................

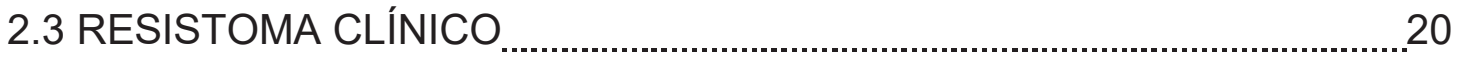

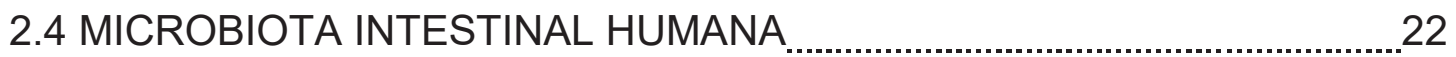

2.4.1 Microbiota como reservatório de genes de resistência ..............24 2.5 ALIMENTOS E DIETA COMO FONTES DE MICRORGANISMOS RESISTENTES

2.6 HÁBITOS ALIMENTARES .................................................................. 31

2.7 FLUXO DE DISSEMINAÇÃO DE RESISTÊNCIA

3 OBJETIVOS

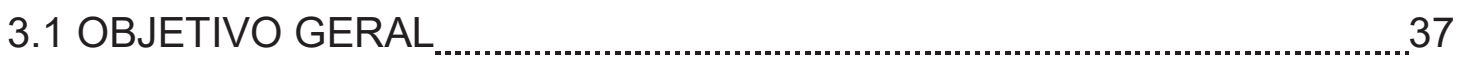

3.2 OBJETIVOS ESPECÍFICOS ................................................................... 37

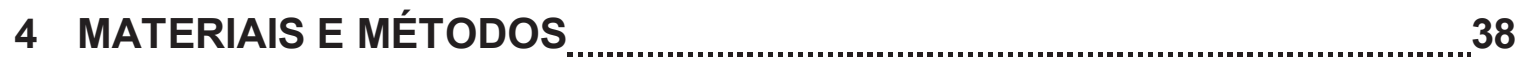

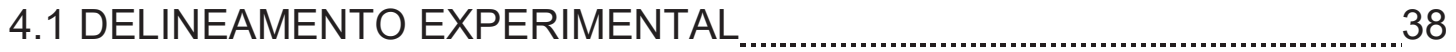

4.2 SELEÇÃO DOS VOLUNTÁRIOS, COLETA E TRATAMENTO DAS AMOSTRAS 39

4.3 EXTRAÇÃO DE DNA DAS AMOSTRAS FECAIS ...................................... 40

4.4 DETECÇÃO DOS GENES DE RESISTÊNCIA ..........................................4

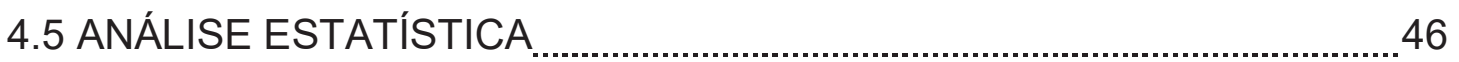

5 RESULTADOS

6 DISCUSSÃO

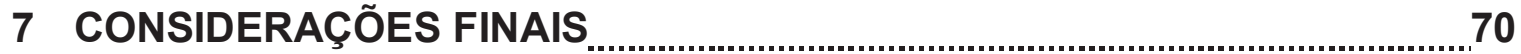

8 CONCLUSÃO

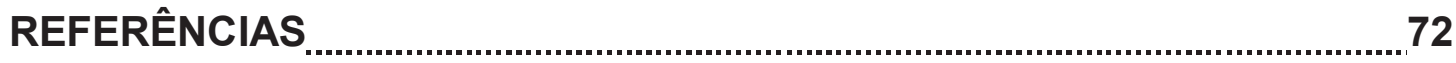

ANEXO A

ANEXO B

ANEXO C

ANEXO D 


\section{INTRODUÇÃO}

O fenômeno da resistência bacteriana aos antimicrobianos está entre os maiores problemas de saúde pública atualmente, sendo motivo de preocupação em escala mundial. É responsável pelo aumento dos custos com tratamento, por maiores taxas de morbidade e mortalidade e pelo prolongamento do período de hospitalização. Há um esforço para a elaboração de estratégias e políticas públicas que sejam aplicáveis e que mostrem bons resultados no controle da disseminação de resistência. Desta forma, muitas medidas vêm sendo propostas, como a educação continuada para prescrição mais prudente de antimicrobianos e a adoção de políticas de controle do uso destas drogas, tanto em saúde humana, quanto em medicina veterinária e na produção de alimentos.

A microbiota intestinal humana $(\mathrm{MIH})$ é considerada um importante reservatório de determinantes genéticos de resistência, uma vez que está sempre em contato com microrganismos ambientais, introduzidos por meio da ingestão de alimentos, água e pelo contato com animais e outras pessoas. A transferência horizontal de genes de resistência pode ocorrer a partir desta interação, e estes genes podem ser transferidos para microrganismos potencialmente patogênicos.

A dieta onívora pode ser considerada a mais comum entre os seres humanos, e indivíduos onívoros consomem alimentos tanto de origem animal quanto vegetal. Dentre as pessoas que adotam uma dieta vegetariana, os indivíduos ovolactovegetarianos têm uma dieta livre de proteína animal, mas que ainda contempla alimentos derivados, como ovos e os a base de leite. Já as pessoas vegetarianas estritas, não consomem alimentos de origem animal, incluindo os derivados. O uso de drogas antimicrobianas na cadeia de produção de diversos alimentos contribui para a seleção de microrganismos resistentes, tornando os alimentos reservatórios de genes de resistência e fontes para sua transferência horizontal. O papel dos alimentos no fluxo de disseminação de resistência é reconhecido e vem sendo demostrado por diversos estudos, os quais influenciaram a implementação de políticas que restringiram o uso de antimicrobianos na cadeia de produção alimentar em alguns países.

As atividades antrópicas produziram mudanças muito expressivas na natureza, e estas atividades passaram a exercer uma pressão seletiva importante 
sobre as comunidades de microrganismos nos mais variados ambientes. O uso de antimicrobianos é considerado uma das forças mais incisivas para a seleção de microrganismos resistentes, e quando os seres humanos passam a utilizar grandes quantidades dessas substâncias na saúde humana e animal, na produção de alimentos, bem como dispensar os rejeitos destas atividades no ambiente, contribuise massivamente para a intensificação dos processos de transferência horizontal e disseminação da resistência bacteriana aos antimicrobianos.

Considerando o papel da microbiota intestinal, dos alimentos e das atividades humanas no fluxo de disseminação de resistência aos antimicrobianos e a necessidade de um melhor entendimento desse fenômeno para a adoção de estratégias e políticas eficazes para seu controle, neste trabalho, pretende-se avaliar a correlação e possível influência de diferentes hábitos alimentares sobre o resistoma clínico da $\mathrm{MIH}$. 


\section{REVISÃO DA LITERATURA}

\subsection{Saúde e resistência bacteriana aos antimicrobianos}

A descoberta das drogas antimicrobianas e sua introdução na prática clínica representam um dos avanços mais importantes em medicina. Seu uso permitiu o tratamento eficaz de doenças infecciosas, aumentando a expectativa de vida dos pacientes e permitindo a execução de procedimentos médicos mais complexos de forma mais segura. Porém, ao longo dos anos, os sistemas de saúde passaram a enfrentar um crescente desafio, quando a resistência bacteriana a estas drogas se tornou um evento rotineiro e um problema de saúde pública mundial (HOLMES et al., 2016; WHO, 2014).

A resistência bacteriana aos antimicrobianos torna o tratamento dos processos infecciosos difícil, custoso e às vezes impossível. Estima-se que a resistência bacteriana aos antimicrobianos dobre o tempo de hospitalização, as taxas de morbidade e mortalidade e os custos de assistência, além de limitar as opções terapêuticas e reduzir a segurança para os pacientes submetidos a procedimentos cirúrgicos, quimioterápicos e transplantes, por exemplo. Os principais facilitadores para a seleção de resistência são: o uso irracional de antimicrobianos; ausência ou inadequação de programas de prevenção e controle de infecções; falhas na fiscalização e regulação do uso de antimicrobianos; vigilância e monitoramento inadequados; baixa qualidade dos medicamentos antimicrobianos e capacidade laboratorial limitada. Se medidas de controle da resistência e disseminação não forem atingidas, estima-se que, até 2050, aproximadamente 10 milhões de pessoas por ano sofram as consequências de infecções causadas por bactérias resistentes aos antimicrobianos (BRASIL, 2017; BRASIL, 2018; O'NEIL et al., 2016).

Considerando a resistência um problema mundial e na tentativa de criar um sistema global e colaborativo de vigilância, em 2015 a Organização Mundial da Saúde (OMS) lançou o Sistema Global de Vigilância de Resistência Antimicrobiana (GLASS), e que até o início de 2020 contava com a participação de 91 países e territórios. Um dos objetivos do GLASS é oferecer um compartilhamento de dados de resistência por país, documentando os resultados nestes países e identificando as diferenças e limitações dos sistemas de vigilância implementados, de forma a 
garantir que os países possam adotar as melhores estratégias de resposta. O Brasil passou a fazer parte do GLASS no ano de 2018 (WHO, 2020).

De acordo com o boletim anual, referente ao ano de 2019, publicado pelo Centro Europeu de Prevenção e Controle de Doenças (ECDC), as taxas de resistência bacteriana aos antimicrobianos na União Europeia permanecem altas, embora haja variações significativas entre os países, dependendo dos grupos de antimicrobianos, das espécies de microrganismos e da região geográfica. A resistência aos carbapenêmicos, por exemplo, mostrou-se acima de 10\% entre Klebsiella pneumoniae e muito comum entre $P$. aeruginosa e Acinetobacter spp., enquanto permaneceu baixa entre isolados de Escherichia coli. Além disso, também foi observado um aumento da porcentagem de isolados de Enterococcus faecium resistentes à vancomicina, de 10,5\% em 2015 para 18,3\% em 2019. No geral, a porcentagem de resistência bacteriana aos antimicrobianos se mostra menor em países mais ao norte do continente, quando comparados com países do sul e leste europeu. Ainda segundo o boletim, a cada ano ocorrem cerca de 670.000 infecções causadas por bactérias resistentes aos antimicrobianos, das quais 33.000 evoluíram para óbito e o custo para os serviços de saúde no manejo destas infecções foi em torno de 1,1 bilhões de euros (ECDC, 2020).

No Brasil, no ano de 2017, a Agência Nacional de Vigilância Sanitária (ANVISA) publicou o Plano Nacional para Prevenção e Controle da Resistência Microbiana nos Serviços de Saúde, baseada na realidade dos serviços de saúde brasileiros, na epidemiologia nacional das infeções por bactérias resistentes e nos objetivos propostos pela OMS segundo seu Plano de Ação Global sobre Resistência aos Antimicrobianos. A elaboração do Plano Nacional tem o objetivo de delinear estratégias em âmbito nacional para detectar, reduzir e prevenir a resistência aos antimicrobianos nos serviços de saúde (BRASIL, 2017).

Segundo o boletim informativo referente ao ano de 2019, publicado pela ANVISA em 2021, dentre os microrganismos Gram-negativos, Klebsiella pneumoniae foi o microrganismo mais frequentemente isolado em pacientes pediátricos e adultos, internados em Centros de Terapia Intensiva (CTI) com infecção primária de corrente sanguínea (IPCS). Acinetobacter baumanniicalcoaceticus foi o que apresentou maior percentual de resistência aos 
antimicrobianos em pacientes adultos internados em CTI com IPCS. Já em CTI pediátrico, Serratia $s p$. foi o microrganismo com maior percentual de resistência. Dentre os Gram positivos, Staphylococcus sp. coagulase negativo apresentou maior percentual de resistência entrre pacientes pediátricos internados em CTI com IPCS. Já entre pacientes adultos, E. faecium apresentou o maior percentual de resistência (BRASIL, 2021).

As infecções por bactérias resistentes aos antimicrobianos são um grande problema tanto em países desenvolvidos quanto em desenvolvimento. Porém, o cenário e o manejo da situação são diferentes e ainda mais desafiadores em países em desenvolvimento, dentre eles o Brasil. A disponibilidade limitada de antimicrobianos e o custo do tratamento representam gargalos financeiros importantes para os sistemas de saúde de muitos destes países, onde a limitação de recursos é uma barreira que favorece a adoção de terapias empíricas que têm chances muito maiores de falha e seleção de microrganismos resistentes. Além disso, em locais de extrema pobreza, a falta de acesso a saneamento, higiene e alimentação tornam as pessoas mais susceptíveis a doenças infecciosas. Esse cenário mostra que o controle da resistência aos antimicrobianos enfrenta desafios adicionais, que estão diretamente relacionados às condições socioeconômicas dos países (AYUKEKBONG, NTEMGWA e ATABE, 2017; SOSA et al., 2010; THAKUR e GRAY, 2019).

Os processos de vigilância permitem a obtenção de dados que irão sustentar o desenvolvimento de estratégias regionais e globais, bem como políticas em saúde que ajudem a intervir de forma mais eficiente para conter o fenômeno da resistência aos antimicrobianos. Entender as bases deste processo, sua dinâmica e os mecanismos de seleção e disseminação permite a elaboração de estratégias mais eficazes e políticas públicas e de vigilância que proporcionem melhores resultados (WHO, 2014).

Medidas educativas que visem diminuir prescrições e práticas inadequadas por parte dos prescritores são estratégias que têm se mostrado eficientes nos vários níveis de atenção e aplicáveis tanto para países desenvolvidos quanto para os países em desenvolvimento. É interessante observar que estas medidas sejam aplicadas desde a época de formação dos profissionais e que permaneçam após a 
graduação. Os programas de educação continuada para prescritores têm mostrado bons resultados, que incluem a redução das prescrições desnecessárias e/ou equivocadas. Tais medidas educativas devem ser estendidas a dispensadores, funcionários de farmácias e outros locais de dispensação, bem como aos pacientes, para que façam o tratamento de forma adequada, mantendo as taxas de aderência altas. O uso prudente de antimicrobianos pode, além disso, ter impacto na diminuição dos custos com tratamento (AYUKEKBONG, NTEMGWA e ATABE, 2017; BHATIA, KATOCH e INOUE, 2019; SYED e BANA, 2016).

Medidas como a elaboração de guias e protocolos de tratamento de infecções nas instituições, criação de comitês de controle de infecção, implementação de políticas de regulação do uso e dispensação de antimicrobianos e a adoção de listas de medicamentos essenciais são estratégias para controle da resistência bacteriana aos antimicrobianos que também se mostram eficazes e menos difíceis de implementar nos países em desenvolvimento (BHATIA, KATOCH e INOUE, 2019; OKEKE et al., 2005). No Brasil, a RENAME (Relação de Medicamentos Essenciais) inclui as drogas antimicrobianas e norteia $O$ atendimento farmacológico e o abastecimento da rede pública de saúde no país (BRASIL, 2020). No ano de 2010, a ANVISA publicou a Resolução da Diretoria Colegiada (RDC) $n^{\circ} 44$, sobre o controle de antimicrobianos, que no ano de 2011 foi revogada pela RDC $n^{\circ} 20$, que está atualmente em vigor e que dispõe sobre o controle de prescrição e dispensação de medicamentos antimicrobianos (BRASIL, 2010; BRASIL, 2011). Estratégias e políticas direcionadas a higiene e ao saneamento básico para a população, bem como as campanhas de vacinação, também previnem as doenças infecciosas, e, consequentemente, reduzem a circulação e disseminação de microrganismos resistentes aos antimicrobianos (THAKUR e GRAY, 2019).

\subsection{Mecanismos de resistência}

Alexander Fleming, em seu discurso durante o prêmio Nobel em 1945, já havia alertado sobre a capacidade dos microrganismos de se tornarem resistentes aos antimicrobianos. De fato, à medida que novos antimicrobianos foram desenvolvidos e passaram a ser utilizados, também foi observada a detecção de 
fenótipos de resistência a estas drogas e a disseminação desses determinantes de resistência entre as populações bacterianas (WHO, 2014).

A resistência bacteriana aos antimicrobianos pode ser definida como a capacidade de um microrganismo resistir à ação de um agente antimicrobiano em doses terapêuticas. A produção de moléculas com atividade antimicrobiana e o desenvolvimento de resistência fazem parte da relação entre os diversos microrganismos pertencentes a um determinado ecossistema. É uma resposta evolutiva frente a uma pressão seletiva e, portanto, irá ocorrer naturalmente no ambiente, a partir do momento em que forças de seleção natural atuarem (ALLEN et al., 2010; MOLLOY e HERTWECK, 2017; HOLMES et al., 2016).

Os antimicrobianos produzidos por microrganismos ambientais têm funções variadas na natureza, como a comunicação celular e homeostasia das comunidades bacterianas, e esta produção é contrabalanceada pela presença de microrganismos resistentes em uma população microbiana equilibrada. Quando é aplicada uma pressão seletiva, como o uso de antibióticos, as bactérias resistentes já existentes naquela população, seja por mutação, aquisição de genes ou resistência intrínseca, são capazes de sobreviver e proliferar (BELL et al., 2014; MOLLOY e HERTWECK, 2017).

O uso de antimicrobianos é uma das forças mais incisivas para que os microrganismos se tornem resistentes. Em termos mais abrangentes, a prevalência de microrganismos resistentes na comunidade é oriunda principalmente do amplo uso dessas substâncias, não só em humanos, mas também na medicina veterinária, na produção de alimentos, na aquicultura e agricultura (CALERO-CÁCERES, YE e BALCÁZAR, 2019; VIKESLAND et al. 2019; WHO, 2012).

A partir da descoberta da penicilina em 1928 até a década de 70, houve o desenvolvimento e introdução de várias novas classes de antimicrobianos para o tratamento das doenças infecciosas, com maior intensidade entre as décadas de 40 e 60. O grande aumento de seu uso favoreceu a seleção de linhagens bacterianas resistentes e a disseminação de determinantes de resistência. Depois da década de 80 , houve uma redução considerável no desenvolvimento de novas drogas, tornando necessário o uso mais ponderado das drogas já disponíveis, para que sua eficiência seja preservada (WHO, 2014). 
Além dos processos de mutação e resistência intrínseca, na qual os genes que conferem resistência fazem parte de forma constitutiva do DNA cromossômico bacteriano, os microrganismos podem se tornar resistentes por meio de transferência horizontal de genes. Esta transferência pode acontecer através dos processos de transformação, transdução ou conjugação, com envolvimento de elementos genéticos móveis (HOLMES et al., 2016; VAN SCHAIK, 2015).

A resistência conferida por mutação é um processo de curso mais lento quando comparada aos mecanismos de transferência horizontal. Exemplos de resistência conferida por mutação são a resistência de Neisseria gonorrhoeae a penicilina e tetraciclina, de Campylobacter jejuni a ciprofloxacina e de Staphylococcus aureus a rifampicina (LEVY e MARSHALL, 2004; MELNYK, WONG e KASSEN, 2015).

A transferência horizontal por transformação ocorre quando uma bactéria capta fragmentos de DNA livre no ambiente, liberados por outros microrganismos, e os incorpora em seu DNA cromossômico. A aquisição de genes por transformação conferiu a Streptococcus pneumoniae o fenótipo de resistência a penicilina, pela captação de fragmentos de DNA de Streptococcus viridans comensais e naturalmente resistentes a penicilinas. Outras bactérias como Acinetobacter baumannii e Haemophilus influenzae também têm grande capacidade de adquirir DNA livre por meio dos processos de transformação (CROUCHER et al., 2016; DOWSON, COFFEY e SPRATT, 1994; SPRATT, 1994).

$\mathrm{Na}$ transdução, a transferência de material genético é mediada por bacteriófagos. Neste processo, o DNA de uma bactéria doadora, armazenado internamente no vírus, é transferido a outra bactéria no momento da infecção viral. Elementos genéticos de resistência podem ser encontrados no DNA de fagos isolados de diversos ambientes, como por exemplo, os genes mecA, que conferem resistência a meticilina em $S$. aureus e alguns genes para $\beta$-lactamases de espectro estendido (ESBL) (CALERO-CÁCERES, YE e BALCÁZAR, 2019; COLOMERLLUCH et al., 2014; LARRAÑAGA, et al., 2018).

A conjugação é o mecanismo de transferência horizontal mais significativo em relação à resistência aos antimicrobianos e sua disseminação. Neste processo, um pili conjugativo é formado entre duas células bacterianas e, através deste, elementos 
genéticos móveis, como plasmídeos, transposons ou integrons são transferidos. A conjugação é responsável pela disseminação de diversos genes de resistência, e é a principal forma de transferência horizontal entre os microrganismos da microbiota intestinal (LOPATKIN et al.,2016; VON WINTERSDORFF et al. 2016;WALSH et al., 2011).

Os mecanismos de aquisição de resistência são variados e os genes podem codificar produtos que irão conferir resistência através de diversas formas. Os genes podem codificar enzimas que irão degradar ou alterar a estrutura do antimicrobiano, fazendo-os perder sua ação, como é o caso de enzimas $\beta$-lactamases. Podem também codificar bombas de efluxo, que atuam no transporte do antimicrobiano, bombeando-o para o meio externo. Este é um dos mecanismos de resistência a tetraciclinas, cloranfenicol e fluoroquinolonas. Podem ainda codificar sítios-alvo modificados, impedindo a ligação da droga, como por exemplo, o gene $\operatorname{mec} A$, que codifica uma proteína de ligação à qual o antimicrobiano não consegue se ligar. A resistência bacteriana a uma determinada classe de antimicrobianos pode ainda ser conferida por determinantes genéticos diferentes, como evidenciado pela grande variedade de genes codificadores de $\beta$-lactamases e bombas de efluxo para tetraciclinas. Além disso, a resistência bacteriana a um determinado antimicrobiano pode ser conferida por meio de mecanismos diferentes, como é o caso da tetraciclina, que pode ter sua ação inibida tanto por bombas de efluxo quanto por proteção do sítio alvo no ribossomo bacteriano (LAKHUNDI e ZHANG, 2018; LEVY e MARSHALL, 2004).

Dentre os microrganismos Gram positivos, Staphylococcus aureus e Enterococcus sp. são os mais relevantes e que representam maiores desafios em relação a resistência bacteriana aos antimicrobianos. S. aureus resistentes a meticilina (MRSA) foi um dos primeiros microrganismos resistentes com impacto mais significativo. O fenótipo MRSA ocorre devido a expressão de uma proteína ligadora de penicilina (PBP) modificada, conhecida como PBP2a, que é codificada pelo gene $\operatorname{mec} A$, horizontalmente transferível. MRSA pode colonizar indivíduos saudáveis e mostra uma distribuição versátil, sendo encontrado tanto em ambientes comunitários como hospitalares, o que merece atenção por parte dos programas de controle de infecção para além de ambientes de cuidados em saúde (BAL et al., 2017; LAKHUNDI e ZHANG, 2018). 
As opções terapêuticas disponíveis incluem glicopeptídeos, linezolida, tigeciclina, daptomicina e $\beta$-lactâmicos, como a ceftarolina, com atividade frente a MRSA. A resistência a essas drogas geralmente é conferida por mutação, mas a transferência horizontal se mostra um mecanismo importante nos casos de resistência a linezolida e glicopeptídeos (BAL et al., 2017; MENDES, DESHPANDE e JONES, 2014; ROSSI et al., 2014). O primeiro caso de $S$. aureus com susceptibilidade reduzida à vancomicina (VISA) na América Latina foi reportado no Brasil, no ano de 2001 (MEJÍA, ZURITA e GUZMÁN-BLANCO, 2010), e o primeiro caso detectado no Brasil de $S$. aureus resistente a vancomicina (VRSA) aconteceu no ano de 2012 (ROSSI et al, 2014).

Enterococcus sp. resistentes a vancomicina (VRE), mais comumente $E$. faecium, são mais restritos a ambientes hospitalares e de cuidados em saúde. Para alguns perfis de paciente, as infecções por VRE são preocupantes, como em pacientes onco-hematológicos e imunocomprometidos. Enterococcus sp. faz parte da microbiota gastrintestinal de seres humanos, e são microrganismos considerados patógenos oportunistas. A maioria das infecções em humanos é causada por $E$. faecalis e E. faecium, tendo origem endógena em muitos dos casos. São microrganismos bastante versáteis e têm capacidade para se tornarem resistentes a diversas drogas, além de apresentarem resistência intrínseca a sulfonamidas, cefalosporinas e baixas concentrações de aminoglicosídeos. A associação de aminoglicosídeos e $\beta$-lactâmicos permite um efeito bactericida que não é observado com o uso destas drogas isoladas. Para o tratamento de VRE, as opções incluem linezolida, quinupristina, dalfopristina, daptomicina. O fenótipo de resistência aos glicopeptídeos é mediado pelo operon van, e os genes vanA e vanB são os mais comumente identificados. O gene vanA, oferece resistência a vancomicina e resistência variável a teicoplanina, e o gene vanB oferece resistência variável a vancomicina, sem ação sobre teicoplanina (FARON, LEDEBOER e BUCHAN, 2016; O'DRISCOLL e CRANK, 2015).

Muitos dos casos de VRE ocorrem quando pacientes já colonizados transmitem, por intermédio de funcionários de unidades de saúde ou pelo ambiente, VRE a outros pacientes susceptíveis dentro da instituição. Desta forma, intervenções como culturas de vigilância, isolamento dos pacientes colonizados por VRE e medidas de higienização podem ser eficientes e limitar a transmissão a pacientes 
susceptíveis (FARON, LEDEBOER e BUCHAN, 2016; O'DRISCOLL \& CRANK, 2015).

Espécies anaeróbicas pertencentes à microbiota gastrintestinal podem carrear genes de resistência a vancomicina, e transferir estes genes a espécies de Enterococcus sp. Stinear e colaboradores (2001), ao investigarem a presença do gene vanB em espécies anaeróbias em amostras de fezes humanas, propõem que, para explicar a grande diversidade de linhagens de VRE nos casos de infecções hospitalares, os VRE que carreiam o gene vanB podem ter adquirido estes genes de espécies anaeróbias pertencentes ao trato gastrintestinal, por meio de transferência horizontal, e quando estes pacientes são expostos a pressão seletiva do antimicrobiano, a seleção destas linhagens resistentes ocorrerá. Estudos posteriores corroboram que o carreamento de genes vanB por microrganismos da microbiota intestinal não pertencentes ao gênero Enterococcus sp., como Clostridium sp. e Streptococcus sp., ocorre em altas taxas. Desta forma, assume-se que bactérias que fazem parte da microbiota gastrintestinal representam um importante reservatório de genes vanB (DOMINGO et al., 2005; GRAHAM et al., 2008; MALIN et al. 2016).

Entre as bactérias Gram-negativas, a resistência aos antimicrobianos caminha para um cenário ainda mais sério e preocupante, sendo comum encontrar fenótipos de resistência à maioria ou a todas as drogas testadas e disponíveis para tratamento. Pseudomonas aeruginosa, grupo Acinetobacter baumanni e enterobactérias como Klebsiella pneumoniae têm posição de destaque neste contexto.

Pseudomonas aeruginosa são microrganismos ubíquos e bastante adaptáveis, mostrando uma plasticidade de metabolismo que os permite colonizar e infectar uma variedade de ambientes, plantas e animais. São oportunistas e importantes agentes de infecções hospitalares, onde é comum detectar fenótipos de resistência à maioria ou a todas as drogas testadas (SILBY et al., 2011; WOODFORD, TURTON e LIVERMORE, 2011). Oferecem altos riscos para pacientes debilitados, imunocomprometidos e em uso de dispositivos implantados, sendo um dos principais agentes responsáveis por pneumonias associadas à ventilação mecânica e em pacientes queimados. São causadores comuns de infecções respiratórias crônicas em pacientes com fibrose cística e cerca de $70 \%$ 
destes pacientes são colonizados de forma crônica por $P$. aeruginosa, que representa uma de suas principais causas de morte. Já foram detectados perfis de multirresistência em $P$. aeruginosa nestes pacientes (HORCAJADA et al., 2019; OLIVER et al., 2015).

Muitos determinantes de resistência são adquiridos por processos de mutação e transferência horizontal. Dentre os genes adquiridos, os que codificam metalo- $\beta$-lactamases são os genes para carbapenemases mais frequentemente encontrados em $P$. aeruginosa (HORCAJADA et al., 2019; RUIZ-GARBAJOSA e CANTÓN, 2017). Há evidências de que clones globais multirresistentes estejam disseminados em escala mundial. Estes clones, denominados clones de alto risco, são encontrados também em pacientes fibrocísticos, não se restringindo, portanto, a pacientes em ambiente hospitalar (OLIVER et al., 2015).

O grupo Acinetobacter baumannii figura entre os microrganismos não fermentadores que mais oferecem desafios ao tratamento. A disseminação rápida de linhagens resistentes evidencia seu alto potencial de responder a adversidades e às pressões seletivas do ambiente. De forma geral, é possível encontrar espécies do gênero Acinetobacter sp. em ambientes como água, solo e colonizando pele e trato gastrintestinal de humanos e animais. São importantes agentes de infecções hospitalares, estando associados principalmente à infecções de trato respiratório, em especial em pacientes em uso de dispositivos implantados, como ventilação mecânica. Apesar de sua predominância em ambiente hospitalar, infeções comunitárias, como pneumonias, já foram descritas, e embora sejam menos frequentes, mostram altas taxas de mortalidade. As linhagens resistentes deixam poucas opções alternativas de tratamento, que incluem carbapenêmicos, polimixinas, minociclina e tigeciclina. $O$ uso de polimixinas como monoterapia ou combinadas com carbapenêmicos (geralmente meropenem), tigeciclina ou rifampicina são opções bastante utilizadas (ALMASAUDI, 2018; GARNACHOMONTERO e TIMSIT, 2019; MEUMANN et al., 2019).

Além dos bacilos Gram-negativos não fermentadores, as enterobactérias também têm destaque no problema da resistência aos antimicrobianos. Quando bactérias produtoras de $\beta$-lactamases do tipo ESBL e AmpC se tornaram frequentes na medicina humana e animal, o tratamento com cefalosporinas de amplo espectro 
passou a ser menos eficiente. A partir de então, os carbapenêmicos passaram a ser amplamente utilizados como drogas de escolha e, à medida que foram mais utilizadas, a resistência a estas drogas passou a ser detectada mais frequentemente (NORDMANN, DORTET e POIREL, 2012). As enterobactérias resistentes aos carbapenêmicos, com destaque para Klebsiella pneumoniae, apresentam este fenótipo de resistência, devido, principalmente, à produção de enzimas do tipo carbapenemases, e os genes que codificam estas enzimas podem ser horizontalmente transferidos, permitindo não só a disseminação entre linhagens da mesma espécie, mas também para outras espécies de importância clínica (LOGAN e WEINSTEIN, 2017; VAN DUIN e DOI, 2017).

\subsection{Resistoma clínico}

O desenvolvimento de técnicas independentes de cultivo para os estudos em microbiologia, dentre eles a metagenômica, permitiu uma nova abordagem para o estudo da resistência bacteriana aos antimicrobianos e seus determinantes genéticos. O metagenoma é definido como o material genético total em um determinado ambiente e é constituído, portanto, de genomas de vários organismos individuais (THOMAS, GILBERT e MEYER, 2012). Dentro do metagenoma, está o resistoma clínico, representado pelo conjunto de genes de resistência aos antimicrobianos de uso clínico. O resistoma clínico é uma pequena porcentagem do resistoma total, o qual é definido como a totalidade de genes associados à resistência em um determinado ambiente, incluindo também os genes de resistência aos metais pesados, antissépticos e outras substâncias tóxicas (GILLINGS, 2013; HO et al, 2020).

O conceito de resistoma é bastante útil nos estudos sobre a resistência bacteriana aos antimicrobianos e de grande importância para um entendimento mais claro de seu fluxo de disseminação. Estudos sobre o resistoma mostram mais claramente como diferentes ambientes e organismos participam deste fluxo como reservatórios. Além disso, evidencia que as bactérias ambientais são provavelmente a origem de genes de resistência e permite o melhor entendimento de quais são os fatores ambientais determinantes para a seleção destes genes e disseminação da resistência (GILLINGS, 2013). 
O aumento do uso de antimicrobianos e xenobióticos ao longo do tempo aumentou a concentração dessas substâncias no ambiente e, consequentemente, o resistoma se tornou mais abundante e mais diverso. O resistoma envolve a resistência intrínseca e a resistência adquirida, a qual pode ocorrer pelos processos de transferência horizontal. Esta transferência permite que os mesmos genes de resistência sejam encontrados em espécies de bactérias diferentes e nos mais variados ambientes. Os genes de proto-resistência também fazem parte do resistoma. Estes genes não conferem fenótipo de resistência em um primeiro momento, mas tem potencial para se tornarem genes de resistência após processos de mutação ou transferência horizontal, que podem alterar sua expressão e passar a conferir o fenótipo de resistência (SINGH, VERMA e TANEJA, 2019; SURETTE e WRIGHT, 2017).

Os elementos genéticos que são capazes de se mover entre as bactérias por transferência horizontal constituem o mobiloma, que inclui plasmídeos, transposons, integrons, sequências de inserção, elementos conjugativos integrativos e fagos. Muitos genes de resistência se encontram em elementos genéticos móveis e podem ser disseminados através da transferência horizontal. Considerando a microbiota intestinal humana, este resistoma móvel é mais frequente em Proteobacteria, seguido de Firmicutes, Actinobacteria e Bacteroidetes (SINGH, VERMA e TANEJA, 2019).

Os integrons são parte do mobiloma e elementos importantes no processo de disseminação de resistência. A estrutura do integron consiste em uma região promotora do cassete genético $(\mathrm{Pc})$, um gene integron-integrase (intl) que codifica uma enzima integrase, seguido de uma região conhecida como sítio de recombinação attl. A integrase catalisa a inserção de elementos genéticos conhecidos como cassetes genéticos no sítio de recombinação attl. Os cassetes são moléculas de DNA circulares, que apresentam uma região ORF (open reading frame) associada ao sítio de recombinação do cassete (attC), que é a região que irá ser integrada ao sítio attl no integron. Vários cassetes podem ser inseridos em sequência no integron, sendo a integrase intl capaz de mediar não só a inserção, mas também a excisão e o arranjo dos cassetes de genes na estrutura do integron. Desta forma, os integrons geram variabilidade genética e fenotípica e também permitem um processo mais rápido de adaptação às pressões de seleção. Sua 
expressão é controlada pelas respostas da bactéria a situações de estresse, que incluem a presença de antimicrobianos (GHALY et al, 2020; MA et al, 2017).

Estima-se que cerca de $17 \%$ dos genomas bacterianos contenham integrons. Os cassetes genéticos são extremamente diversos e bastante difundidos no ambiente e, portanto, bactérias portadoras de um integron têm acesso a esta grande diversidade genética oferecida pelos cassetes. Muitos genes de resistência estão presentes em cassetes, e vários integrons que já foram sequenciados contém genes de resistência adquiridos. Os integrons podem ser classificados em 5 classes diferentes, e esta classificação é baseada na sequência que codifica a enzima integrase (intl). As classes 1,2 e 3 são as mais frequentemente associadas aos fenótipos de multirresistência aos antimicrobianos (GHALY et al, 2020; MA et al, 2017; RANJBAR et al, 2018).

\subsection{Microbiota intestinal humana}

A microbiota intestinal humana (MIH) desempenha diversas funções importantes para o hospedeiro, e o equilíbrio desta relação influencia seu estado de saúde. Ela está envolvida em processos de maturação e diferenciação de células intestinais, captação de nutrientes, proteção contra a entrada de patógenos e na modulação do sistema imune. Alterações no estado de equilíbrio da microbiota estão relacionadas com diversas condições como obesidade, doenças inflamatórias, alergias e doenças autoimunes (LANGE et al., 2016; MILANI et al., 2017).

De forma geral, embora existam estudos que sugerem que a exposição aos microrganismos se inicia ainda na vida intrauterina, os seres humanos começam a ser rapidamente colonizados ao nascimento, por microrganismos que farão parte da da microbiota indígena, oriundos do ambiente, água e alimentos que ingerimos. A microbiota inicial é influenciada principalmente pelo modo de nascimento e formas de alimentação, bem como pelas condições sanitárias e o uso de antibióticos nesse período (MILANI et al., 2017). É possível encontrar bactérias resistentes aos antimicrobianos em praticamente todos os tipos de ambientes, e, dessa forma, é esperado que estas bactérias se comportem como membros da microbiota residente 
desde o início da vida (RUBIN, EKANAYAKE e FERNANDO, 2014; SWIFT et al., 2019; WALSH et al., 2011).

Em termos gerais, a dieta é o principal modulador da microbiota. No início da vida, antes do estabelecimento de uma microbiota estável, a microbiota de crianças recém-nascidas, com menos de 1 ano de vida, é caracterizada por apresentar uma baixa diversidade de microrganismos e alto fluxo bacteriano, até aproximadamente os 2-3 anos de idade. Inicialmente, bactérias anaeróbicas facultativas e aerotolerantes colonizam o trato gastrintestinal, criando um ambiente que favorece o desenvolvimento e estabelecimento de microrganismos anaeróbios. Bactérias do Filo Actinobacteria e Firmicutes são predominantes nesta etapa da vida. Os principais representantes do filo Firmicutes são bactérias do ácido-láctico, como Lactobacillus sp., Enterococcus sp. e Clostridium sp. As bactérias do gênero Bifidobacterium sp. são membros do filo Actinobacteria e são importantes produtores de ácidos graxos de cadeia curta e colonizadores iniciais em neonatos (MILANI et al., 2017; VOREADES, KOZIL e WEIR, 2014).

Após o desmame e início da alimentação com alimentos sólidos, a microbiota muda consideravelmente, com aumento da diversidade, predominância dos filos Bacteroidetes e Firmicutes e aumento de bactérias produtoras de butirato e outros ácidos graxos de cadeia curta, em resposta aos alimentos consumidos na dieta, principalmente amido e fibras. Os ácidos graxos de cadeia curta são importantes para a fisiologia do cólon, sendo fontes de energia para os enterócitos, estimulantes de proliferação celular, fluxo sanguíneo visceral e processos de absorção, além de estimular a produção de substâncias que previnem a entrada de patógenos. Muitas bactérias produtoras dessas substâncias são pertencentes aos filos predominantes, como Firmicutes e Actinobacteria. A partir de 2 a 3 anos, o perfil da microbiota passa a se apresentar mais semelhante ao da microbiota adulta, e a composição variada da dieta continua sendo sua principal força moduladora (CASALS-PASCUAL, VERGARA e VILA, 2018; VOREADES, KOZIL e WEIR, 2014; WONG et al. 2006).

Em adultos, a microbiota apresenta-se mais estável e é composta por microrganismos pertencentes a até sete filos distintos, com Bacteroidetes e Firmicutes sendo os mais abundantes. Membros do filo Proteobacteria, como Enterobactérias e Gram-negativos não fermentadores, estão em menor proporção 
entre os microrganismos que compõem a microbiota. Firmicutes e Proteobacteria são menos estáveis e mais responsivos a perturbações do que Bacteroidetes e Actinobacteria (VOREADES, KOZIL e WEIR, 2014).

A partir dos estudos de Arumugam e colaboradores (2011) e Wu e colaboradores (2011), sugeriu-se uma classificação que fosse baseada em padrões de composição da microbiota. Subsequentemente, observou-se que havia padrões de variação na microbiota intestinal que eram reprodutíveis entre indivíduos adultos, e quando estas variações foram agrupadas, passaram a ser denominadas enterotipos. Cada enterotipo tem a predominância de um determinado gênero bacteriano e são bastante estáveis. Eles são moldados em resposta à dieta e apenas dietas de longa duração os influenciam de forma significativa. Existem, até então, 3 enterotipos: o enterotipo 1 ou Bacteroides, o enterotipo 2 ou Prevotella e o enterotipo 3 ou Ruminococcus. Devido ao grau de complexidade do ecossistema intestinal, esta classificação permanece muito desafiadora e, apesar de se mostrar um método útil na tentativa de se estratificar os microbiomas intestinais humanos, estudos recentes buscam esclarecer e melhorar esta classificação (COSTEA et al., 2018; MOSCHEN, WIESER e TILG, 2012).

Uma dieta rica em proteína animal e em gorduras saturadas direciona para o enterotipo Bacteroides, estando associado a uma dieta ocidental. Em contrapartida, dietas com menos consumo destes nutrientes, ricas em carboidratos e açúcares simples, direcionam para o enterotipo Prevotella. Vegetarianos mostram maior predominância deste enterotipo. Uma alimentação rica em fibras está associada com a predominância dos filos Bacteroidetes e Actinobacteria, enquanto dietas hipercalóricas, com alto consumo de gorduras e açúcares estão associadas a um aumento de Firmicutes e Proteobacteria (MOSCHEN, WIESER e TILG, 2012).

\subsubsection{Microbiota como reservatório de genes de resistência}

Os alimentos também são uma fonte para a introdução de novos microrganismos no trato gastrintestinal. Além dos alimentos, o trato gastrintestinal está sempre entrando em contato com bactérias do ambiente por meio da água, solo, animais e pelo contato com outras pessoas. Estas bactérias que entram em 
contato com a microbiota intestinal podem albergar genes de resistência, os quais podem ser transferidos aos microrganismos comensais, incluindo os potencialmente patogênicos (BAQUERO, 2012; CANIÇA et al., 2018).

Uma variedade muito grande de genes de resistência já foi identificada na microbiota intestinal. Estudos já mostraram que Escherichia coli em humanos saudáveis albergam uma grande variedade de genes de resistência (BAILEY et al., 2010). De acordo com Bartoloni e colaboradores (2009), em indivíduos de comunidades remotas na América do Sul, sem uso prévio de antibióticos, foram encontradas bactérias resistentes a pelo menos um antibiótico em 2/3 destes indivíduos. Clemente e colaboradores (2015), ao caracterizarem o microbioma e resistoma de Yanomanis em comunidades isoladas, sem contato documentado com civilização urbana e sem exposição prévia a antibióticos, detectaram, além de uma expressiva diversidade de microrganismos na microbiota, vários genes de resistência, inclusive a antibióticos sintéticos. Os autores sugerem que estes genes tenham chegado a estas comunidades por meio de mecanismos de resistência cruzada ou por fluxo de disseminação entre as populações mais modernas e estes povos isolados. Os trabalhos de Bag e colaboradores (2019) e Gumpert e colaboradores (2017) também evidenciaram a presença de diversos genes de resistência em bactérias comensais da microbiota intestinal, bem como de mecanismos de transferência horizontal e persistência destes genes mesmo sem a pressão seletiva de antimicrobianos, sugerindo que estes microrganismos comensais são um reservatório importante destes genes, e podem transferi-los a outros microrganismos.

A transferência horizontal de genes pode acontecer a partir da interação da microbiota com microrganismos oriundos do ambiente. A transferência horizontal é facilitada quando ocorre entre microrganismos pertencentes ao mesmo filo, filogeneticamente próximos e que coabitam os mesmos nichos. Além disso, a formação de biofilmes e a alta densidade populacional de microrganismos também facilitam a transferência de material genético. Portanto, o trato gastrintestinal é um ambiente propício para a transferência horizontal de determinantes genéticos (POPA e DAGAN, 2011; SORENSEN et al., 2005; THOMAS e NIELSEN, 2005) 
As atividades humanas influenciam de forma expressiva o ambiente e a composição da microbiota. À medida que foram ocorrendo mudanças nos hábitos e atividades ao longo do tempo, estes fatores tiveram um impacto direto em nossa microbiota, alterando sua composição e os genes circulantes entre os microrganismos, mas nenhuma força foi tão marcante como o início do uso de agentes antimicrobianos (GILLINGS, PAULSEN e TETU, 2015; SWIFT et al., 2019).

Em relação às forças de seleção atuando sobre a microbiota humana ao longo do tempo, as populações pré-históricas, com atividades de caça e colheita, além das comunidades agrárias, eram expostas a áreas geográficas menores e tinham contato, consequentemente, com menos determinantes genéticos e microrganismos. Além desse contato com áreas geográficas menores, as seleções a que a microbiota estava sujeita se resumiam à seleção pelos componentes da dieta, que modulavam as populações microbianas, sua variação genética e capacidade de metabolizar os componentes da alimentação, podendo ser considerada uma seleção de curso mais lento. Ao longo do tempo e com a revolução industrial, a microbiota passou a ser exposta a novos agentes, que passaram a exercer uma seleção mais expressiva. O aumento da capacidade de locomoção e maior exploração de recursos naturais tiveram um impacto importante, aumentando o contato com novos microrganismos e permitindo o trânsito e disseminação destes para áreas mais distantes. Na atualidade, a globalização permite a circulação de microrganismos e determinantes genéticos por todo o mundo, possibilitando o contato de um indivíduo com bactérias e genes oriundos de qualquer lugar. A introdução de substâncias como biocidas, desinfetantes, metais pesados e antibióticos passou a exercer uma pressão seletiva incisiva, selecionando os microrganismos resistentes e permitindo sua disseminação e seu estabelecimento entre os membros da microbiota. Antes da revolução industrial e do início do uso de substâncias antimicrobianas, é provável que os genes de resistência a drogas usadas na clínica não fossem tão frequentes entre os microrganismos da microbiota residente (GILLINGS, PAULSEN e TETU, 2015; SOMMER et al., 2017).

A dieta, doenças do hospedeiro, sua genética e infecções por outros agentes, como parasitas e vírus, podem ter um impacto na comunidade microbiana de forma a deixá-la mais propensa a transferir determinantes genéticos de resistência. Membros do Filo Proteobacteria, os quais estão em proporções menores na 
microbiota, têm maiores tendências para a mobilização de elementos genéticos de resistência, podendo apresentar analogia de cerca de metade dos elementos genéticos do seu resistoma com os genes de resistência conhecidos na clínica. Portanto, se mostram componentes importantes no fluxo de genes entre fontes ambientais, microbiota e patógenos (BAQUERO, 2012; SOMMER, $\mathrm{CHURCH}$ e DANTAS, 2010). Claeson e colaboradores (2011), ao estudarem a microbiota de pessoas idosas, geralmente mais vulneráveis a doenças infecciosas, observaram um predomínio 10 vezes maior de bactérias do filo Proteobacteria. Vários estudos têm demonstrado o aumento de Proteobacteria em diversas doenças, principalmente doenças metabólicas, como obesidade e diabetes, e doenças inflamatórias, como doença de Crohn e colite ulcerativa, sugerindo que níveis variados de inflamação sejam o aspecto central da relação entre o aumento de Proteobacteria e as doenças em que este aumento é observado (RIZZATTI et al., 2017). É possível afirmar que fatores como idade, alimentação e hábitos de vida influenciam no estado da microbiota, podendo torná-la mais propensa à transferência de determinantes genéticos.

A terapia antimicrobiana causa alterações significativas na estrutura e diversidade da comunidade microbiana no trato gastrintestinal, podendo influenciar seu equilíbrio com o hospedeiro. Apesar de a microbiota se mostrar resiliente e ser capaz de restabelecer suas funções principais, sua diversidade pode não retornar ao seu estado original e, além disso, os genes de resistência podem ser carreados por longos períodos após a exposição, dependendo do antimicrobiano utilizado (LANGE et al., 2016; SOMMER et al., 2017).

A microbiota tem se mostrado um reservatório importante para o transporte de genes de resistência, permitindo que estejam presentes por todo o mundo. O estudo de Bengtsson-Palme e colaboradores (2015) demonstra como a microbiota pode atuar como transportador de determinantes genéticos entre os continentes. Ao analisarem amostras de fezes de estudantes suecos antes e após viagens para África Central e Península Indiana, observaram que após as viagens a microbiota albergava mais determinantes genéticos de resistência, maior proporção de Proteobacteria e, entre os que viajaram para Península Indiana, mais da metade passou a carrear E. coli produtora de ESBL. É interessante observar que o perfil das comunidades microbianas presentes no local de destino, os hábitos alimentares 
locais e as políticas de uso de antimicrobianos do país também contribuem para a maior aquisição de bactérias resistentes aos antimicrobianos.

\subsection{Alimentos e dieta como fontes de microrganismos resistentes}

O uso de antimicrobianos durante o processo de produção de alimentos pode ter fins terapêuticos, profiláticos ou como promotores de crescimento. Seu uso está relacionado com a seleção de bactérias resistentes e transferência horizontal de genes para microrganismos patogênicos. Os microrganismos presentes nos alimentos são fontes reconhecidas de genes de resistência, e a relação entre alimentos e resistência vem sendo considerada um fator importante no processo de disseminação de bactérias resistentes. Os antimicrobianos usados nas cadeias de produção de alimentos são os mesmos ou são pertencentes às mesmas classes dos usados para tratamento em seres humanos, tornando elevado o risco de resistência cruzada (CANIÇA et al., 2019; KOCH, HUNGATE e PRICE, 2017).

Quando são usados em animais, exercem uma pressão seletiva que seleciona microrganismos resistentes em sua microbiota, que podem chegar aos seres humanos através dos alimentos. A resistência pode ser detectada, inclusive, em microrganismos comensais de alimentos fermentados derivados de leite e carne. Em locais onde antibióticos não são muito usados nos animais, observa-se maiores taxas de susceptibilidade entre as bactérias do ácido-lático (BAL) isoladas de produtos derivados. Em contrapartida, em locais onde a prática é intensa, maiores são as taxas de resistência encontradas (COMUNIAN et al., 2009; MORAČANIN et al, 2017). Atualmente, a União Europeia e diversos outros países, incluindo o Brasil, proíbem o uso da maioria dos antibióticos como promotores de crescimento, havendo evidências de quedas na prevalência de resistência em animais após esta medida (ABRIOUEL et al., 2017; CASEWELL et al., 2003; MORAČANIN et al, 2017).

Vários estudos evidenciam o fluxo de disseminação de resistência entre alimentos e humanos. Os estudos realizados por Levy e colaboradores, no ano de 1976, foram um dos primeiros a demonstrar este fluxo. Após tratamento de frangos com oxitetraciclina como promotor de crescimento, foi observada a colonização destes frangos por $E$. coli resistente a tetraciclina e, posteriormente, a presença 
deste perfil de resistência em E. coli da microbiota intestinal de moradores locais do estabelecimento (LEVY, FITZGERALD e MACONE, 1976a; LEVY, FITZGERALD e MACONE, 1976b). De forma semelhante, Looft e colaboradores (2012), em estudo com porcos que receberam clortetraciclina, sulfametoxazina e penicilina, observaram que genes de resistência aumentaram entre os microrganismos gastrintestinais destes animais, que passaram inclusive, a albergar genes de resistência a antimicrobianos não administrados, como aminoglicosídeos, evidenciando possível seleção indireta a outras classes de drogas.

Na revisão de Hammerum e colaboradores (2010), relatam a ocorrência de resistência cruzada entre antibióticos usados na produção de alimentos e os usados para tratamento em humanos. A resistência cruzada pode conferir resistência a todos os antibióticos pertencentes a uma determinada classe de antibiótico, ainda que a exposição seja a apenas uma droga, já que compartilham o mesmo modo de ação e sítio alvo (WRIGHT, 2003). Os autores mostraram a correlação entre o uso de avoparcina na cadeia de produção de alimentos com a seleção e disseminação de Enterococcus resistentes a vancomicina (VRE). Após a suspensão do uso de avoparcina na União Europeia, em 1997, observou-se, de forma geral, um decréscimo na prevalência de VRE.

Mais recentemente, estudos de Amador e colaboradores (2019) ao analisarem a presença de bactérias resistentes e determinantes genéticos de resistência em estrume de aves, suínos, animais de matadouros e da produção leiteira em Portugal, encontraram uma alta prevalência de enterobactérias multirresistentes no estrume de gado e altas taxas de resistência entre amostras de suínos. Estes exemplos evidenciam que bactérias resistentes selecionadas durante a cadeia de produção de alimentos podem ser transferidas a humanos durante este processo. O contato com animais de estimação e outros reservatórios também têm efeito semelhante.

Em alimentos fermentados, as BAL são usualmente utilizadas nos processos fermentativos durante a produção e podem ser originadas do ambiente, préexistentes nos alimentos crus, ou então serem adicionadas por meio de misturas comerciais. Têm sido descritos uma variedade de determinantes genéticos de resistência nestas bactérias, apesar de a maioria não ser patogênica. Dentre as BAL 
estão os gêneros Lactobacillus, Bifidobacterium e Enterococcus (ABRIOUEL et al, 2017; DEVIRGILIIS, BARILE e PEROZZI, 2011).

É possível encontrar microrganismos ambientais em alimentos, mesmo que seu processamento seja feito sob boas condições de higiene. As espécies de Lactobacillus sp. ambientais e outras BAL, por exemplo, podem sobreviver durante o processo de produção, passando a fazer parte da microbiota de uma grande variedade destes alimentos, como laticínios e carnes. A persistência desses microrganismos nos alimentos processados e fermentados faz com que possam alcançar e interagir com a microbiota intestinal. A transferência de genes pode ocorrer durante qualquer fase do processo, mas é favorecida pela alta densidade microbiana observada no trato gastrintestinal (AARTS e MARGOLLES; 2015; TURPIN et al., 2010).

A transferência do gene de resistência a tetraciclinas tet(S), localizado em plasmídeos, de espécies de Enterococcus italicus em leite fermentado para $E$. faecalis por conjugação foi observada nos estudos de Zago e colaboradores (2010). De forma semelhante, o gene tet(M) plasmidial em Lactococcus lactis foi transferido para E. faecalis com bastante eficiência em ensaios de conjugação in vitro realizados por Devirgiliis e colaboradores (2010). Bactérias do gênero Bifidobacterium sp. apresentam, com muita frequência, o gene tet $(W)$, porém não foi descrita a transferência horizontal para bactérias potencialmente patogênicas. Considerando seu amplo uso na produção de alimentos fermentados e sua predominância como membros da microbiota nas fases iniciais da vida, são importantes os estudos que avaliem a capacidade de transferência horizontal de genes de resistência por estas bactérias (GUEIMONDE et al., 2013). Já Coton e colaboradores (2018) observaram o fenótipo de resistência e a produção de aminas biogênicas em BAL destinadas ao uso como bioprotetores em produtos alimentícios. Os autores destacam a necessidade de garantir que estes critérios de segurança sejam triados antes de se considerar uma determinada linhagem como agente bioprotetor de alimentos, devido à possibilidade de transferência horizontal de genes de resistência e virulência para outras bactérias.

$\mathrm{Na}$ aquicultura, o uso de antimicrobianos pode ser feito diretamente na água ou na ração, o que torna o ambiente aquático um importante reservatório de 
bactérias resistentes e genes de resistência. Muitos determinantes de resistência em patógenos humanos têm sua origem em ambientes aquáticos, já que estes determinantes podem ser encontrados em vários patógenos de animais aquáticos. Há relatos, por exemplo, da transferência de plasmídeos contendo genes de resistência entre espécies de Aeromonas de peixes para espécies de Salmonella sp. e E. coli. O contato direto com a água e a ingestão de água e peixes têm efeito semelhante na disseminação de determinantes genéticos de resistência (CABELLO, 2006; HEUER et al., 2009; JANG et al., 2018; WELLINGTON et al., 2013).

A higienização deficiente e lavagem inadequada de frutas e vegetais frescos antes do consumo também podem torná-los fontes de bactérias resistentes. Um exemplo interessante, descrito por Raphael e colaboradores (2011), é a detecção de genes blactX-M codificadores de ESBL em Pseudomonas teessidea, isoladas de espinafres pré-embalados. A utilização de fezes de animais como fertilizantes na agricultura também tem papel importante na disseminação de resistência através dos alimentos (AMADOR et al., 2019).

\subsection{Hábitos alimentares}

Como os hábitos alimentares são moduladores conhecidos da microbiota gastrintestinal e são fontes para a introdução de substâncias e microrganismos ambientais, é esperado que mudanças nas quantidades consumidas de nutrientes, como carboidratos, proteínas e gorduras, causem alterações na composição da microbiota intestinal humana $(\mathrm{MIH})$. Dentre os diferentes tipos de hábitos alimentares, a dieta onívora, ovolactovegetariana e vegetariana estrita têm sido bastante estudadas. A MIH apresenta características de resiliência e é relativamente estável ao atingirmos a vida adulta, dessa forma, apenas as dietas de longa duração que são capazes de causar alterações significativas no perfil da microbiota (MOSCHEN, WIEGER e TILG, 2012; ZHANG et al., 2018).

Diferenças entre a MIH de onívoros, ovolactovegetarianos e veganos são demonstradas por diversos estudos (LOSASSO et al., 2018a; MATIJAŠIĆ et al., 2014; ZHANG et al., 2018; ZIMMER et al., 2012). De forma geral, as contagens totais de microrganismos permanecem inalteradas entre pessoas onívoras, 
ovolactovegetarianas e veganas. Quando comparados com onívoros, os indivíduos veganos e ovolactovegetarianos mostraram decréscimo nas contagens de bactérias do gênero Bacteroides. Tal observação pode ser explicada considerando que bactérias pertencentes a este gênero estão associadas a dietas mais ricas em proteína e gordura animal. As contagens de bactérias do filo Bacteroidetes são maiores em indivíduos ovolactovegetarianos e vegetarianos estritos quando comparados com indivíduos onívoros. Indivíduos veganos e ovolactovegetarianos mostraram menor prevalência de Bifidobacterium sp. e um aumento de Prevotella sp., quando comparados com onívoros. Já em relação a Proteobacteria, indivíduos veganos mostraram menor prevalência destas bactérias quando comparados com onívoros e ovolactovegetarianos. Proteobacteria usam preferencialmente proteínas como sua principal fonte de energia e, por isso, indivíduos com dieta pobre em proteínas e rica em polissacarídeos mostraram menores contagens de Proteobacteria. Outra possível explicação é devido ao pH mais baixo das fezes de indivíduos veganos, visto que diversas espécies de enterobactérias, como $E$. coli, não toleram bem ambientes mais ácidos (FERROCINO et al, 2015; LOSASSO et al., 2018a; MOSCHEN, WIEGER e TILG, 2012; SAKKAS et al., 2020; ZIMMER et al., 2012).

Além de hábitos alimentares, as análises da composição da microbiota de diferentes grupos de indivíduos mostraram que o local onde estas pessoas vivem, o qual tem relação com as formas de produção e os tipos de alimentos produzidos e consumidos, têm um grande impacto para determinar a composição da microbiota intestinal. Alguns estudos puderam agrupar melhor os participantes por áreas geográficas do que apenas por hábitos alimentares, demonstrando que, além dos hábitos alimentares, os tipos de alimentos consumidos e o local de moradia dos indivíduos podem ter grande influência sobre a microbiota e serem responsáveis por sua composição (FERROCINO et al., 2015; SENGHOR et al., 2018; TYAKHT et al., 2013).

Por definição, animais onívoros são aqueles que consomem alimentos de origem vegetal e animal, com capacidade para metabolizar ambos os tipos alimentos (DE ATTAYDE, ISKIN e CARNEIRO, 2006; DICIO, 2018). A onivoria é menos restrita do que a dieta de animais herbívoros e carnívoros e é bastante comum na natureza, podendo ter um papel de estabilizar a dinâmica das cadeias alimentares. A 
dieta onívora é a mais comum entre humanos, os quais são considerados animais onívoros. Porém, além dos fatores biológicos, determinantes culturais e sociais têm grande influência em sua dieta e escolhas alimentares (DE ATTAYDE, ISKIN e CARNEIRO, 2006; FILHO e BARROSO, 2007).

Os indivíduos veganos, além de adotarem uma dieta vegetariana estrita, também não utilizam em sua rotina outros produtos de origem animal. Uma dieta vegetariana estrita não contempla alimentos de origem animal, incluindo derivados, como leite, queijos, ovos e mel. Desta forma, o veganismo é definido como um estilo de vida que mantém tanto a dieta quanto hábitos de vida sem quaisquer produtos originados de animais. Já os ovolactovegetarianos não consomem carne, mas mantém uma dieta que ainda inclui alimentos derivados, como os a base de leite e ovos (CHERRY, 2006; DWYER, 1991; SAKKAS et al, 2020).

Dentre as motivações para adotar o vegetarianismo como estilos de vida estão motivos diretamente relacionados aos animais, que envolvem o bem-estar animal, os direitos dos animais e outras questões éticas; os motivos pessoais, que incluem o estado de saúde, o bem-estar e gostos pessoais, como sabor e textura dos alimentos; e motivos ambientais, que abrangem a preservação de recursos naturais, proteção ambiental e mudanças climáticas decorrentes de atividades humanas. Os motivos relacionados aos animais são os que têm maior peso nas decisões pela mudança do estilo de vida, enquanto os motivos pessoais e a preocupação com a saúde aparecem como o segundo principal motivo. O vegetarianismo, de forma geral, apresenta motivações que têm forte caráter filosófico e ético. Quanto mais sólidas são as convicções pessoais e quanto mais pessoas próximas têm hábitos semelhantes, mais fácil é manter este estilo de vida (JANSSEN et al., 2016; RUBY, 2012; SAKKAS et al., 2020).

\subsection{Fluxo de disseminação de resistência}

Os genes de resistência presentes em microrganismos patogênicos podem, em parte, ter origem de microrganismos ambientais. Muitos desses genes não conferem fenótipos de resistência em seu ambiente "natural", tanto por terem outras funções, já que estão em um contexto diferente, quanto por terem expressão 
regulada, podendo necessitar de outro tipo de estímulo para serem expressos. Quando estes genes são transferidos, estando agora em outro tipo de ambiente, eles deixam de ter a regulação de antes e passam a ser expressos e conferir o fenótipo de resistência (BERGLUND, 2015; DANTAS e SOMMER, 2012; GILLINGS, PAULSEN e TETU, 2015). Ao serem expostas aos antimicrobianos, as bactérias podem fixar estes genes adquiridos, mas apenas os genes que não tiverem custos metabólicos muitos altos se tornarão genes presentes em altas densidades (BAQUERO, TEDIM e COQUE, 2013).

Mudanças severas ocorreram na natureza por consequência de atividades humanas, as quais introduziram uma pressão seletiva extra e passaram a exercer uma poderosa força sobre as comunidades microbianas em todo o mundo, selecionando microrganismos e influenciando os processos de variação genética dentro das comunidades microbianas. Tais mudanças se intensificaram quando grandes quantidades de antimicrobianos passaram a ser utilizados nas práticas em saúde, na produção de alimentos e também após a dispensação dos rejeitos oriundos destas atividades no ambiente. Os efeitos de outras substâncias, como pesticidas, metais pesados e resíduos de produção industrial também tem efeito cumulativo, e seu descarte no ambiente facilita a transferência e disseminação de determinantes genéticos. As forças físicas e biológicas atuam neste ciclo, contribuindo para a completa disseminação de marcadores genéticos de resistência para praticamente todos os ambientes do mundo (BERGLUND, 2015; VIKESLAND et al., 2019; ALLEN et al., 2010).

Os estudos de Karkman e colaboradores (2019) sugerem que a abundância de genes de resistência em ambientes com impacto de atividades humanas pode ser mais relacionada à contaminação fecal do que a uma seleção natural, a qual ocorreria mais evidentemente em ambientes poluídos com altas quantidades de antimicrobianos. Os autores ainda destacam a necessidade de considerar esta poluição fecal como um determinante importante para explicar a presença de genes de resistência nos ambientes, evitando conclusões equivocadas sobre uma possível seleção natural ambiental.

Um exemplo interessante que evidencia o fluxo de genes entre reservatórios ambientais e patógenos são os genes blactX-M, que codificam para enzimas ESBL. 
Estes genes tem provável origem de espécies do gênero Kluyvera sp., que podem ser encontradas em ambientes como solo, água, alimentos de origem animal, esgotos e como membros da microbiota (CANTÓN, GONZÁLEZ-ALBA e GALÁN, 2012).

A resistência aos antimicrobianos tem diversos determinantes, e várias são as forças responsáveis por sua disseminação. De forma geral, há as forças físicas, representadas pela água e pelo vento, que mobilizam os microrganismos do ambiente, podendo movimentá-los entre os continentes (VIKESLAND et al., 2019). Os animais, incluindo humanos, representam as forças biológicas de movimentação. Diversos estudos já mostraram que animais selvagens que vivem próximos a ambientes urbanos carreiam mais genes de resistência entre os membros de sua microbiota. Isso evidencia como as atividades humanas influenciam o ambiente, fazendo com que as comunidades microbianas em ambientes selvagens também sejam afetadas (SWIFT et al, 2019; FURNESS et al., 2017; GILLIVER et al., 1999; ROLLAND et al., 1985). Muitos animais selvagens são migratórios e podem percorrer grandes distâncias e, consequentemente, disseminar e transportar os genes de resistência. As aves migratórias, por exemplo, podem ter papel importante na disseminação de bactérias resistentes (CAO et al, 2020), e pássaros que fazem seus ninhos próximos à água e ambiente contaminados com esgoto ou rejeitos albergam mais bactérias resistentes (COLE et al., 2005; DOLEJSKA,CIZEK e LITERAZ, 2007). Da mesma forma, animais selvagens de países que mostram alto uso de antibióticos também carreiam mais microrganismos resistentes. Os animais de estimação, consequentemente, também são reservatórios de genes de resistência, tanto pelo contato com humanos, quanto por serem eventualmente tratados de infecções (VIKESLAND et al., 2019; ALLEN et al., 2010).

O solo é um dos reservatórios de genes de resistência mais ricos. Cerca de $80 \%$ dos antimicrobianos usados na clínica tem origem de bactérias do solo, e apresentar genes de resistência é uma vantagem adaptativa de autoproteção para estas bactérias (D'COSTA, GRIFFITHS e WRIGHT, 2007). D'Costa e colaboradores (2011), ao analisarem amostras de sedimentos datados de muitos mil anos atrás, pré uso de antimicrobianos, detectaram genes de resistência a $\beta$-lactâmicos, glicopeptídeos e tetraciclinas. A posterior análise estrutural e funcional de elementos vanA de resistência a vancomicina evidenciou similaridade entre os determinantes 
de amostras antigas e modernas. Estas observações mostraram que muitos genes que codificam resistência existem desde antes do começo do uso de antimicrobianos pelos seres humanos, evidenciando que a resistência em si é um fenômeno muito antigo, natural e difundido por todo o ambiente. Isso pode ser um dos motivos da rápida seleção e disseminação de resistência em saúde, já que é possível que novos antimicrobianos tenham selecionado determinantes genéticos pré-existentes no ambiente (D'COSTA et al., 2011).

O fenômeno de resistência aos anticrobianos e sua ampla distribuição exemplificam e retratam muito bem o conceito One Health (Saúde Única), criado em 2004 e definido como um esforço múltiplo interdisciplinar que trabalha local, nacional e globalmente para alcançar a saúde humana, animal e ambiental. Este conceito tem uma visão mais abrangente de saúde, onde a saúde humana não é um domínio isolado, mas está conectada à saúde animal e ao ambiente. Esta ampla distribuição de microrganismos resistentes e de seus marcadores genéticos evidencia a conexão entre os três domínios (humano, animal e ambiental), permitindo que seja observado o fluxo de disseminação destes determinantes entre eles. Desta forma, uma abordagem eficiente e que guie políticas públicas eficazes dependerá da compreensão da importância de cada domínio no processo, das maneiras como interagem e do fluxo de transmissão (DESTOUMIEUX-GARZÓN et al, 2018; ROBINSON et al., 2016). 


\section{OBJETIVOS}

\subsection{Objetivo Geral}

Correlacionar a presença de determinantes genéticos de resistência a antimicrobianos comumente utilizados em medicina humana com os hábitos alimentares de indivíduos onívoros, ovolactovegetarianos e vegetarianos estritos.

\subsection{Objetivos Específicos}

- Realizar a avaliação nutricional e medidas antropométricas de indivíduos voluntários para caracterização de onívoros, ovolactovegetarianos e vegetarianos estritos na cidade de Juiz de Fora, MG.

- Obter DNA metagenômico a partir de amostras de fezes dos voluntários previamente caracterizados como onívoros, ovolactovegetarianos e vegetarianos estritos.

- Detectar, por biologia molecular, a presença de determinantes genéticos de resistência aos antimicrobianos mais comumente utilizados na medicina humana, em amostras fecais obtidas de indivíduos onívoros, ovolactovegetarianos e vegetarianos estritos.

- Correlacionar a presença de determinantes genéticos de resistência com os diferentes hábitos alimentares dos voluntários. 


\section{MATERIAL E MÉTODOS}

\subsection{Delineamento experimental}

O delineamento experimental ocorreu conforme o fluxograma (Figura 1) abaixo:

Figura 1 - Fluxograma do delineamento experimental utilizado para estudo da ocorrência de determinantes genéticos de resistência a drogas antimicrobianas no metagenoma intestinal e sua correlação com diferentes hábitos alimentares.

Seleção de voluntários onivoros, ovolactovegetarianos e vegetarianos estritos na comunidade

\section{\ل}

Avaliação nutricional e determinação de medidas antropométricas<smiles>[C]=C</smiles>

Coleta de amostras de fezes e extração de DNA metagenômico<smiles>[CH]=C</smiles>

Quantificação e avaliação de integridade do DNA extraido<smiles>C1=CC=C1</smiles>

Pesquisa de genes de resistência à drogas antimicrobianas

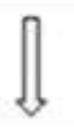

Correlaçăo entre os diferentes tipos de hábitos alimentares e a ocorrência de determinantes genéticos de resistência 


\subsection{Seleção dos voluntários, coleta e tratamento das amostras}

O presente estudo é do tipo transversal, descritivo e observacional, realizado com indivíduos onívoros, ovolactovegetarianos e vegetarianos estritos, selecionados na comunidade, entre o período de abril de 2018 a dezembro de 2019, na cidade de Juiz de Fora, Minas Gerais. Os critérios de inclusão foram: ter idade entre 18 a 60 anos, seguir dieta onívora, ovolactovegetariana ou vegetariana estrita por 1 ano ou mais, ter índice de massa corporal (IMC) entre 18,5 e 25 , não ter usado antimicrobianos nos últimos 3 meses, não estar grávida ou amamentando e não ter patologias como diabetes, hipertensão, câncer, artrite reumatoide ou outras patologias. O estudo foi aprovado pelo Comitê de Ética em Pesquisa com Seres Humanos da Universidade Federal de Juiz de Fora, com parecer número 2.046.122 (Anexo B). Todos os voluntários foram informados a respeito do estudo e seus objetivos e assinaram o Termo de Consentimento Livre e Esclarecido (Anexo C).

Na avaliação antropométrica, foram aferidos o peso e a altura dos voluntários. A aferição do peso foi feita em balança digital com o indivíduo em posição central, ereto, descalço, com os pés juntos e usando o mínimo de roupa possível. A altura foi aferida por meio de estadiômetro vertical fixo à balança, com o voluntário também descalço e ereto, com calcanhares unidos, sem adereços na cabeça e olhando para o horizonte. O IMC foi calculado a partir da relação entre peso e altura $\left(\mathrm{Kg} / \mathrm{m}^{2}\right)$ e avaliado de acordo com o proposto pela Organização Mundial de Saúde (WHO, 2000).

Para diminuir variações na tomada de medidas neste estudo, as medidas foram aferidas sempre pelo mesmo estudante da faculdade de Nutrição, usando a mesma fita métrica e balança. Desta forma, com base nestes critérios, foram selecionados, no total, 58 indivíduos divididos em 3 grupos com hábitos alimentares diferentes: 19 onívoros (ON), 20 ovolactovegetarianos (VT) e 19 vegetarianos estritos (VG).

Para avaliar a ingestão alimentar regular dos voluntários, aplicou-se um questionário quantitativo de frequência alimentar (QQFA) adaptado (Anexo D). Para cada item do QQFA, validado por Cardoso e Stocco (2000), os voluntários informavam a frequência média de consumo habitual (diária, semanal e mensal) 
relativa aos últimos seis meses e o tamanho da porção ingerida. Um álbum fotográfico elaborado por Sales, Costa e Silva (2004), o qual contém imagens de diferentes tamanhos de porções dos alimentos questionados, foi utilizado para ajudar os participantes na estimativa do tamanho das porções.

As amostras de fezes foram coletadas por demanda espontânea pelos participantes, em recipientes coletores universais estéreis e fornecidos pelos pesquisadores. Assim que colhidas, as amostras foram enviadas ao Laboratório de Fisiologia e Genética Molecular Microbiana no CEMIC (Centro de Estudos em Microbiologia) do Instituto de Ciências Biológicas da Universidade Federal de Juiz de Fora, onde foram aliquotadas. Para extração do DNA metagenômico, foram pesados $200 \mathrm{mg}$ de fezes e armazenados em freezer a $-80^{\circ} \mathrm{C}$.

\subsection{Extração de DNA das amostras fecais}

O DNA metagenômico foi extraído utilizando-se o kit comercial QIAamp ${ }^{\mathrm{TM}}$ Fast DNA Stool Mini Kit (Qiagen, Hilden, Alemanha), de acordo com as instruções do fabricante. O DNA extraído foi eluído em volume de $50 \mu \mathrm{L}$ e mantido em freezer $20^{\circ} \mathrm{C}$ para estudos posteriores. A quantificação e pureza do DNA metagenômico foram determinadas por meio de espectrofotometria, utilizando-se o espectrofotômetro Thermo Scientific NanoDrop ${ }^{\text {TM }} 2000$ (Thermo Fisher Scientific, Waltham, MA, EUA). A integridade do DNA foi avaliada por eletroforese em gel de agarose a $0,8 \%$ em tampão TBE 0,5X (Tris-HCl-Borato-EDTA). O gel foi corado com brometo de etídio e analisado em transiluminador de luz ultravioleta (GE Healthcare, Reino Unido).

\subsection{Detecção dos genes de resistência}

O resistoma clínico avaliado neste estudo foi composto por um conjunto de 37 determinantes genéticos de resistência a antimicrobianos comumente utilizados na medicina humana, incluindo determinantes relacionados a bombas de efluxo e integrons de classes 1, 2 e 3 (Tabela 1). Estes determinantes de resistência foram pesquisados a partir do DNA metagenômico extraído das amostras fecais, 
utilizando-se a técnica de PCR convencional, com primers específicos e condições de amplificação já descritas na literatura (Tabela 1).

As reações de PCR foram realizadas em volumes de $25 \mu \mathrm{L}$, contendo $12,5 \mu \mathrm{L}$ de PCR Master Mix (Promega, Madison, WI, USA) e $1 \mu \mathrm{L}$ de DNA ( 20 ng/ $\mu \mathrm{L})$. Os volumes dos primers variaram de acordo com a referência utilizada e completou-se com água o volume de $25 \mu \mathrm{L}$. As reações ocorreram em termociclador automatizado (Biometra T1 Thermocycler, Gttingen, Alemanha). Após a reação de PCR, realizouse eletroforese em gel de agarose a 1,0\% e, em seguida, o gel foi corado com brometo de etídio e visualizado em transiluminador ultravioleta (GE Healthcare, Reino Unido). Foi utilizado o padrão de peso molecular 100bp DNA ladder (Promega, Madison, WI, USA). Para cada reação de PCR, foram utilizados controles positivos e negativos. 
Tabela 1. Determinantes genéticos de resistência pesquisados, oligonucleotídeos iniciadores, tamanho dos amplicons esperados e referências

\begin{tabular}{|c|c|c|c|c|c|}
\hline Marcador & $\begin{array}{l}\text { Mecanismo de } \\
\text { Resistência }\end{array}$ & $\begin{array}{l}\text { Antimicrobianos } \\
\text { alvo }\end{array}$ & Sequência (5'-3') & $\begin{array}{l}\text { Amplicon } \\
\text { (bp) }\end{array}$ & Referência \\
\hline blactX-M & $\begin{array}{l}\text { Inativação enzimática } \\
\text { ( } \beta \text {-lactamase })\end{array}$ & $\beta$-lactâmicos & $\begin{array}{l}\text { ATG TGC AGY ACC AGT AAA G } \\
\text { GGT CAC CAG AAG GAG C }\end{array}$ & 562 & Jones et al., 2009 \\
\hline blakPC & $\begin{array}{l}\text { Inativação enzimática } \\
\text { ( } \beta \text {-lactamase })\end{array}$ & $\beta$-lactâmicos & $\begin{array}{l}\text { ATG TCA CTG TAT CGC CGT CT } \\
\text { TTT TCA GAG CCT TAC TGC CC }\end{array}$ & 892 & Jones et al., 2009 \\
\hline blasHV & $\begin{array}{l}\text { Inativação enzimática } \\
\text { ( } \beta \text {-lactamase })\end{array}$ & $\beta$-lactâmicos & $\begin{array}{l}\text { CTT TAC TCG CCT TTA TCG GC } \\
\text { TTA CCG ACC GGC ATC TTT CC }\end{array}$ & 982 & Jones et al., 2009 \\
\hline bla $_{T E M}$ & $\begin{array}{l}\text { Inativação enzimática } \\
\quad(\beta \text {-lactamase })\end{array}$ & $\beta$-lactâmicos & $\begin{array}{c}\text { GTG CGC GGA ACC CCT ATT } \\
\text { TTA CCA ATG CTT AAT CAG TGA GGC }\end{array}$ & 968 & Jones et al., 2009 \\
\hline blaoxA-23 & $\begin{array}{l}\text { Inativação enzimática } \\
\text { ( } \beta \text {-lactamase })\end{array}$ & $\beta$-lactâmicos & $\begin{array}{l}\text { GAT CGG ATT GGA GAA CCA GA } \\
\text { ATT TCT GAC CGC ATT TCC AT }\end{array}$ & 501 & Woodford et al., 2006 \\
\hline blaoxA-51 & $\begin{array}{l}\text { Inativação enzimática } \\
\text { ( } \beta \text {-lactamase })\end{array}$ & $\beta$-lactâmicos & $\begin{array}{l}\text { TAA TGC TTT GAT CGG CCT TG } \\
\text { TGG ATT GCA CTT CAT CTT GG }\end{array}$ & 353 & Woodford et al., 2006 \\
\hline blaZ & $\begin{array}{l}\text { Inativação enzimática } \\
\text { ( } \beta \text {-lactamase })\end{array}$ & $\beta$-lactâmicos & $\begin{array}{l}\text { ACT TCA ACA CCT GCT GCT TTC } \\
\text { TGA CCA CTT TTA TCA GCA ACC }\end{array}$ & 173 & Martineu et al., 2000 \\
\hline bla $a_{a m p c}$ & $\begin{array}{l}\text { Inativação enzimática } \\
\text { ( } \beta \text {-lactamase })\end{array}$ & $\beta$-lactâmicos & $\begin{array}{l}\text { CTG TTC GAG ATC GGC TC } \\
\text { CGG TAT AGG TCG CGA G }\end{array}$ & 166 & Xavier et al., 2010 \\
\hline bla $_{S P M-1}$ & $\begin{array}{l}\text { Inativação enzimática } \\
\quad(\beta \text {-lactamase) }\end{array}$ & $\beta$-lactâmicos & $\begin{array}{l}\text { CCT ACA ATC TAA CGG CGA CC } \\
\text { TCG CCG TGT CCA GGT ATA AC }\end{array}$ & 649 & Gales et al., 2003 \\
\hline mecA & Sítio-alvo modificado & $\beta$-lactâmicos & $\begin{array}{l}\text { GTA GAA ATG ACT GAA CGT CCG ATA A } \\
\text { CCA ATT CCA CAT TGT TTC GGT CTA A }\end{array}$ & 310 & Zhang et al., 2004 \\
\hline
\end{tabular}


Tabela 1. Continuação

\begin{tabular}{|c|c|c|c|c|c|}
\hline Marcador & $\begin{array}{l}\text { Mecanismo de } \\
\text { Resistência }\end{array}$ & $\begin{array}{c}\text { Antimicrobianos } \\
\text { alvo }\end{array}$ & Sequência (5'-3') & $\begin{array}{l}\text { Amplicon } \\
\text { (bp) }\end{array}$ & Referência \\
\hline $\operatorname{tet}(A)$ & Bomba de efluxo & Tetraciclinas & $\begin{array}{l}\text { GCT ACA TCC TGC TTG CCT TC } \\
\text { CAT AGA TCG CCG TGA AGA GG }\end{array}$ & 210 & Ng et al., 2001 \\
\hline $\operatorname{tet}(B)$ & Bomba de efluxo & Tetraciclinas & $\begin{array}{l}\text { TTG GTT AGG GGC AAG TTT TG } \\
\text { GTA ATG GGC CAA TAA CAC CG }\end{array}$ & 659 & Ng et al., 2001 \\
\hline $\operatorname{tet}(E)$ & Bomba de efluxo & Tetraciclinas & $\begin{array}{l}\text { AAA CCA CAT CCT CCA TAC GC } \\
\text { AAA TAG GCC ACA ACC GTC AG }\end{array}$ & 278 & Ng et al., 2001 \\
\hline $\operatorname{tet}(K)$ & Bomba de efluxo & Tetraciclinas & $\begin{array}{l}\text { GTA GCG ACA ATA GGT AAT AGT } \\
\text { GTA GTG ACA ATA AAC CTC CTA }\end{array}$ & 360 & Strommenger et al., 2003 \\
\hline $\operatorname{tet}(L)$ & Bomba de efluxo & Tetraciclinas & $\begin{array}{l}\text { TCG TTA GCG TGC TGT CAT TC } \\
\text { GTA TCC CAC CAA TGT AGC CG }\end{array}$ & 267 & $\mathrm{Ng}$ et al., 2001 \\
\hline $\operatorname{tet}(M)$ & Proteção ribossomal & Tetraciclinas & $\begin{array}{l}\text { AGT GGA GCG ATT ACA GAA } \\
\text { CAT ATG TCC TGG CGT GTC TA }\end{array}$ & 158 & Strommenger et al., 2003 \\
\hline $\operatorname{tet}(0)$ & Proteção ribossomal & Tetraciclinas & $\begin{array}{c}\text { AGC GTC AAA GGG GAA TCA CTA TCC } \\
\text { CGG CGG GGT TGG CAA ATA }\end{array}$ & 1723 & Trzcinski et al., 2000 \\
\hline $\operatorname{tet}(Q)$ & Proteção ribossomal & Tetraciclinas & $\begin{array}{l}\text { TTA TAC TTC CTC CGG CAT CG } \\
\text { ATC GGT TCG AGA ATG TCC AC }\end{array}$ & 904 & $\mathrm{Ng}$ et al., 2001 \\
\hline$m s r A$ & Bomba de efluxo & $\begin{array}{l}\text { Macrolídeos/ } \\
\text { estreptogramina B }\end{array}$ & $\begin{array}{l}\text { TCC AAT CAT AGC ACA AAA TC } \\
\text { AAT TCC CTC TAT TTG GTG GT }\end{array}$ & 163 & Chaieb et al., 2007 \\
\hline mef & Bomba de efluxo & Macrolídeos & $\begin{array}{l}\text { AGT ATC ATT AAT CAC TAG TGC } \\
\text { TTC TTC TGG TAC AAA AGT GG }\end{array}$ & 348 & Chaieb et al., 2007 \\
\hline
\end{tabular}


Tabela 1. Continuação

\begin{tabular}{|c|c|c|c|c|c|}
\hline Marcador & $\begin{array}{l}\text { Mecanismo de } \\
\text { Resistência }\end{array}$ & $\begin{array}{c}\text { Antimicrobianos } \\
\text { alvo }\end{array}$ & Sequência (5'-3') & $\begin{array}{l}\text { Amplicon } \\
\text { (bp) }\end{array}$ & Referência \\
\hline $\operatorname{erm}(A)$ & Sítio alvo modificado & MLS* & $\begin{array}{l}\text { AAG CGG TAA ACC CCT CTG A } \\
\text { TTC GCA AAT CCC TTC TCA AC }\end{array}$ & 190 & $\begin{array}{l}\text { Strommenger et al., } \\
2003\end{array}$ \\
\hline $\operatorname{erm}(B)$ & Sítio alvo modificado & MLS* & $\begin{array}{l}\text { CTA TCT GAT TGT TGA AGA AGG ATT } \\
\text { GTT TAC TCT TGG TTT AGG ATG AAA }\end{array}$ & 142 & Martineau et al., 2000 \\
\hline $\operatorname{erm}(C)$ & Sítio alvo modificado & MLS* & $\begin{array}{l}\text { AAT CGT CAA TTC CTG CAT GT } \\
\text { TAA TCG TGG AAT ACG GGT TTG }\end{array}$ & 299 & $\begin{array}{l}\text { Strommenger et al., } \\
2003\end{array}$ \\
\hline $\operatorname{ere}(A)$ & $\begin{array}{l}\text { Inativação enzimática } \\
\text { (eritromicina esterase) }\end{array}$ & Macrolídeos & $\begin{array}{l}\text { AAC ACC CTG AAC CCA AGG GAC G } \\
\text { CTT CAC ATC CGG ATT CGC TCG A }\end{array}$ & 420 & Sutcliffe et al., 1996 \\
\hline $\operatorname{ere}(B)$ & $\begin{array}{l}\text { Inativação enzimática } \\
\text { (eritromicina esterase) }\end{array}$ & Macrolídeos & $\begin{array}{l}\text { AGA AAT GGA GGT TCA TAC TTA CCA } \\
\text { CAT ATA ATC ATC ACC AAT GGC A }\end{array}$ & 546 & Sutcliffe et al., 1996 \\
\hline$q n r B$ & Proteção sítio alvo & Quinolonas & $\begin{array}{l}\text { GAT CGT GAA AGC CAG AAA GG } \\
\text { ATG AGC AAC GAT GCC TGG TA }\end{array}$ & 476 & Kim et al., 2009 \\
\hline qnrS & Proteção sítio alvo & Quinolonas & $\begin{array}{l}\text { GCA AGT TCA TTG AAC AGG GT } \\
\text { TCT AAA CCG TCG AGT TCG GCG }\end{array}$ & 428 & Kim et al., 2009 \\
\hline sul1 & Sítio alvo modificado & Sulfonamidas & $\begin{array}{l}\text { ATG GTG ACG GTG TTC GGC ATT CTG A } \\
\text { CTA GGC ATG ATC TAA CCC TCG GTC T }\end{array}$ & 815 & $\begin{array}{l}\text { Grape, Sundstrom e } \\
\text { Kronvall, } 2003\end{array}$ \\
\hline sul2 & Sítio alvo modificado & Sulfonamidas & $\begin{array}{l}\text { CCT GTT TCG TCC GAC ACA GA } \\
\text { GAA GCG CAG CCG CAA TTC AT }\end{array}$ & 396 & $\begin{array}{l}\text { Addos, Shubbar e } \\
\text { Hindi2013 }\end{array}$ \\
\hline
\end{tabular}


Tabela 1. Continuação

\begin{tabular}{|c|c|c|c|c|c|}
\hline Marcador & $\begin{array}{l}\text { Mecanismo de } \\
\text { Resistência }\end{array}$ & $\begin{array}{l}\text { Antimicrobianos } \\
\text { alvo } \\
\end{array}$ & Sequência (5'-3') & $\begin{array}{l}\text { Amplicon } \\
\text { (bp) }\end{array}$ & Referência \\
\hline aacA-aphD & $\begin{array}{l}\text { Inativação enzimática } \\
\text { (acetiltransferase) }\end{array}$ & Aminoglicosídeos & $\begin{array}{l}\text { TAA TCC AAG AGC AAT AAG GGC } \\
\text { GCC ACA CTA TCA TAA CCA CTA }\end{array}$ & 227 & Strommenger et al., 2003 \\
\hline $\operatorname{mex} B$ & Bomba de efluxo & ** & $\begin{array}{l}\text { GTG TTC GGC TCG CAG TAC TC } \\
\text { AAC CGT CGG GAT TGA CCT TG }\end{array}$ & 244 & Yoneda et al., 2005 \\
\hline $\operatorname{mex} D$ & Bomba de efluxo & ** & $\begin{array}{l}\text { CGA GCG CTA TTC GCT GC } \\
\text { GGC AGT TGC ACG TCG A }\end{array}$ & 165 & Xavier et al., 2010 \\
\hline $\operatorname{mexF}$ & Bomba de efluxo & ** & $\begin{array}{l}\text { CGC CTG GTC ACC GAG GAA GAG T } \\
\text { TAG TCC ATG GCT TGC GGG AAG C }\end{array}$ & 255 & Amin et al., 2005 \\
\hline $\operatorname{mex} Y$ & Bomba de efluxo & ** & $\begin{array}{l}\text { CCG CTA CAA CGG CTA TCC CT } \\
\text { AGC GGG ATC GAC CAG CTT TC }\end{array}$ & 250 & Yoneda et al., 2005 \\
\hline Int/1 & $\begin{array}{l}\text { Integração de } \\
\text { cassetes genéticos } \\
\text { que podem conter } \\
\text { genes de resistência }\end{array}$ & Integron Classe 1 & $\begin{array}{l}\text { GGT CAA GGA TCT GGA TTT CG } \\
\text { ACA TGC GTG TAA ATC ATC GTC }\end{array}$ & 436 & Machado et al., 2005 \\
\hline $\ln t / 2$ & $\begin{array}{l}\text { Integração de } \\
\text { cassetes genéticos } \\
\text { que podem conter } \\
\text { genes de resistência }\end{array}$ & Integron Classe 2 & $\begin{array}{l}\text { CAC GGA TAT GCG ACA AAA AGG } \\
\text { TGTA GCA AAC GAG TGA CGA AAT G }\end{array}$ & 788 & Machado et al., 2005 \\
\hline $\ln t / 3$ & $\begin{array}{c}\text { Integração de } \\
\text { cassetes genéticos } \\
\text { que podem conter } \\
\text { genes de resistência }\end{array}$ & Integron Classe 3 & $\begin{array}{l}\text { AGT GGG TGG CGA ATG AGT G } \\
\text { TGT TCT TGT ATC GGC AGG TG }\end{array}$ & 600 & Machado et al., 2005 \\
\hline
\end{tabular}

**Bombas de efluxo que conferem resistência a diferentes drogas antimicrobianas 


\subsection{Análise Estatística}

Para avaliar o agrupamento por similaridade das amostras de acordo com a presença/ ausência de genes de resistência, foi construído um dendrograma com base no coeficiente Dice de similaridade e no método UPGMA (Unweighted Pair Group Method with Arithmetic Averages) para análise dos agrupamentos. $O$ programa utilizado para construção do dendrograma foi o programa PAST versão 4.03.

O teste $\mathrm{t}$ de Student foi utilizado para comparação entre as frequências alimentares dos macronutrientes, obtidas a partir do QQFA, com nível de significância de $5 \%(p=0,05)$ e utilizando o programa estatístico XLSTAT. 


\section{RESULTADOS}

Os dados sociodemográficos, antropométricos e nutricionais dos participantes são apresentados na Tabela 2. A idade média foi de $28.66( \pm 7.79)$ anos e o IMC médio foi de 21,90. Em relação à distribuição por gênero, 25,9\% eram do sexo masculino e $74,1 \%$ do feminino. Não foram observadas diferenças significativas na ingestão média diária de calorias, no entanto, o consumo de lipídios foi maior no grupo ON quando comparado ao VG. Em relação à ingestão de proteínas, o consumo foi diferente entre os três grupos, sendo maior em onívoros. O consumo de carboidratos foi significativamente maior entre o grupo VG do que nos dois outros grupos e não houve diferenças significativas entre ON e VT. Em relação ao consumo de fibras totais, fibras insolúveis e fibras solúveis, o consumo entre VG foi maior quando comparado aos outros dois grupos. O comportamento alimentar dos participantes do grupo $\mathrm{ON}$ foi relacionado a um menor consumo de fibras. 
Tabela 2. Características sociodemográficas, antropométricas e nutricionais dos participantes

\begin{tabular}{|c|c|c|c|c|}
\hline \multirow{2}{*}{$\begin{array}{l}\text { Características } \\
\text { (média } \pm \text { DP) }\end{array}$} & \multicolumn{3}{|c|}{ Grupo de participantes } & \multirow{2}{*}{$p<0.05^{\star}$} \\
\hline & ON $(n=19)$ & VT $(n=20)$ & VG $(n=19)$ & \\
\hline $\begin{array}{l}\text { Gênero (\%; masculino/ } \\
\text { feminino) }\end{array}$ & $15,8 / 84,2$ & $20,0 / 80,0$ & $42,1 / 57,9$ & na \\
\hline $\begin{array}{l}\text { Idade média } \\
\text { (anos } \pm \text { DP) }\end{array}$ & $28,47 \pm 6,02$ & $31,63 \pm 9,72$ & $25,89 \pm 6,24$ & na \\
\hline \multirow{4}{*}{$\begin{array}{c}\text { Grupos } \\
\text { étinicos (\%) }\end{array}$} & 52,6 & 78,9 & 89,5 & na \\
\hline & 31,6 & 10,6 & 10,5 & na \\
\hline & 10,5 & 10,5 & & na \\
\hline & 5,3 & & & na \\
\hline $\begin{array}{l}\text { Média do Índice de Massa } \\
\text { Corporal (IMC) }\end{array}$ & $21,46 \pm 1,96$ & $22,13 \pm 1,95$ & $22,12 \pm 1,72$ & - \\
\hline $\begin{array}{l}\text { Ingestão média diária de } \\
\text { calorias (kcal) }\end{array}$ & $2049,28 \pm 836,12$ & $2092,37 \pm 738,86$ & $2522,74 \pm 955,18$ & - \\
\hline $\begin{array}{l}\text { Ingestão média diária de } \\
\text { carboidratos (\%) }\end{array}$ & $47,39 \pm 7,35$ & $54,26 \pm 13,95$ & $64,73 \pm 11,34$ & b, c \\
\hline $\begin{array}{l}\text { Ingestão média diária de } \\
\text { lipídios (\%) }\end{array}$ & $33,39 \pm 6,07$ & $33,64 \pm 14,41$ & $25,10 \pm 12,11$ & c \\
\hline $\begin{array}{l}\text { Ingestão média diária de } \\
\text { proteínas }(\%)\end{array}$ & $19,22 \pm 4,80$ & $12,10 \pm 3,16$ & $10,17 \pm 1,91$ & $a, b, c$ \\
\hline $\begin{array}{l}\text { Ingestão média diária de } \\
\text { fibras totais }(\mathrm{g})\end{array}$ & $23,01 \pm 9,04$ & $41,98 \pm 25,12$ & $63,78 \pm 35,79$ & $a, b, c$ \\
\hline $\begin{array}{l}\text { Ingestão média diária de } \\
\text { fibras solúveis }(\mathrm{g})\end{array}$ & $2,53 \pm 1,56$ & $4,98 \pm 2,53$ & $13,58 \pm 14,65$ & $a, b, c$ \\
\hline $\begin{array}{l}\text { Ingestão média diária de } \\
\text { fibras insolúveis }(\mathrm{g})\end{array}$ & $5,14 \pm 3,27$ & $8,88 \pm 5,41$ & $21,42 \pm 19,36$ & $a, b, c$ \\
\hline
\end{tabular}

*Análise estatística significativa: a- comparação entre os valores dos voluntários ON e VT; bcomparação entre valores de voluntários VT e VG; c- comparação entre os valores de voluntários ON e VG. ${ }^{* *} A$ etnia Pardo é usada no Brasil para se referir a pessoas de ancestralidade étnica mista e representa uma diversidade de origens étnicas. ON = onívoros, VT = ovolactogetarianos, VG = vegetarianos estritos, DP = Desvio Padrão, na = não se aplica.

Dos 37 genes de resistência a antimicrobianos (ARG) testados, 22 foram detectados em pelo menos um grupo de participantes. Dentre os determinantes genéticos detectados, os genes que conferem resistência às tetraciclinas foram os mais observados entre os três grupos, seguidos dos genes de resistência ao grupo 
MLS e macrolídeos e dos genes de resistência a $\beta$-lactâmicos. (Figura 2). Os genes $\operatorname{tet}(M), \operatorname{tet}(Q)$ e $\operatorname{tet}(O)$ e o gene $\operatorname{erm}(B)$ foram detectados em todas as amostras analisadas. $O$ gene blaтем e $\mathrm{O}$ gene mef foram detectados com uma frequência acima de $70 \%$ nos 3 grupos. O gene aacA-aphD também foi detectado com frequência, variando de $37 \%$ em vegetarianos estritos a $55 \%$ em ovolactovegetarianos. Os genes de resistência às sulfonamidas, sul1 e sul2, e de resistência às quinolonas, qnrB e qnrS, e os genes intl-1 tiveram frequências intermediárias de detecção (Figura 3). Foram observados 15 determinantes comuns entre todos os grupos avaliados. Os determinantes qnrS e intl-2 foram encontrados nos grupos de onívoros e ovolactovegetarianos, enquanto $\operatorname{erm}(A)$ e tet( $L)$ foram detectados somente em onívoros e vegetarianos estritos. Já o marcador blaZ foi encontrado em ovolactovegetarianos e vegetarianos estritos. O marcador blacTX-M foi detectado em uma única amostra do grupo de ovolactovegetarianos e tet(E) em apenas uma amostra do grupo de onívoros (Figura 4). 
Figura 2. Distribuição dos determinantes genéticos entre os indivíduos onívoros (ON), ovolactovegetarianos (VT) e vegetarianos estritos (VG) de acordo com a classe dos antimicrobianos alvos dos produtos de expressão destes genes

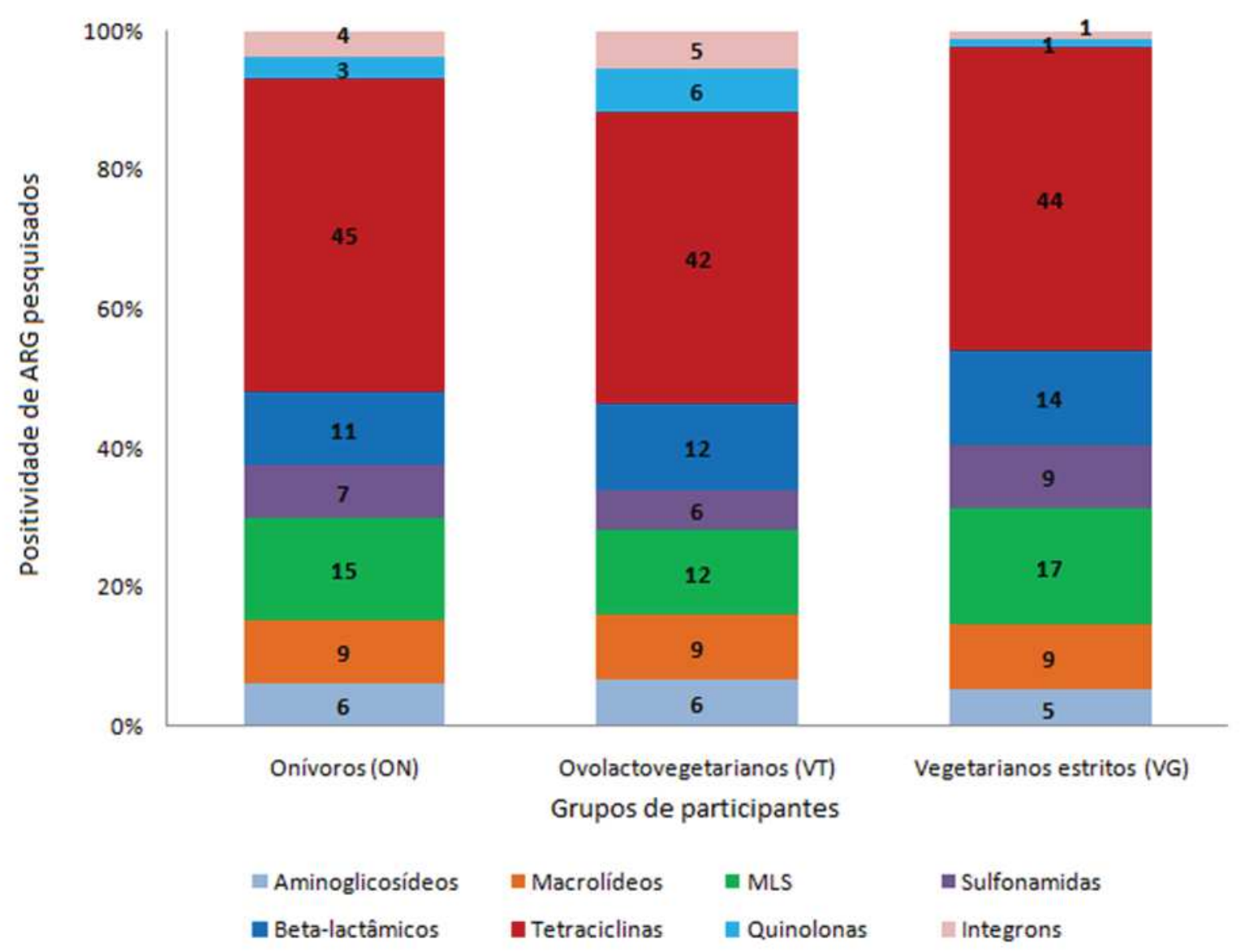


Figura 3. Distribuição dos determinantes genéticos de resistência detectados entre os grupos de indivíduos onívoros (ON), ovolactovegetarianos (VT) e vegetarianos estritos (VG)

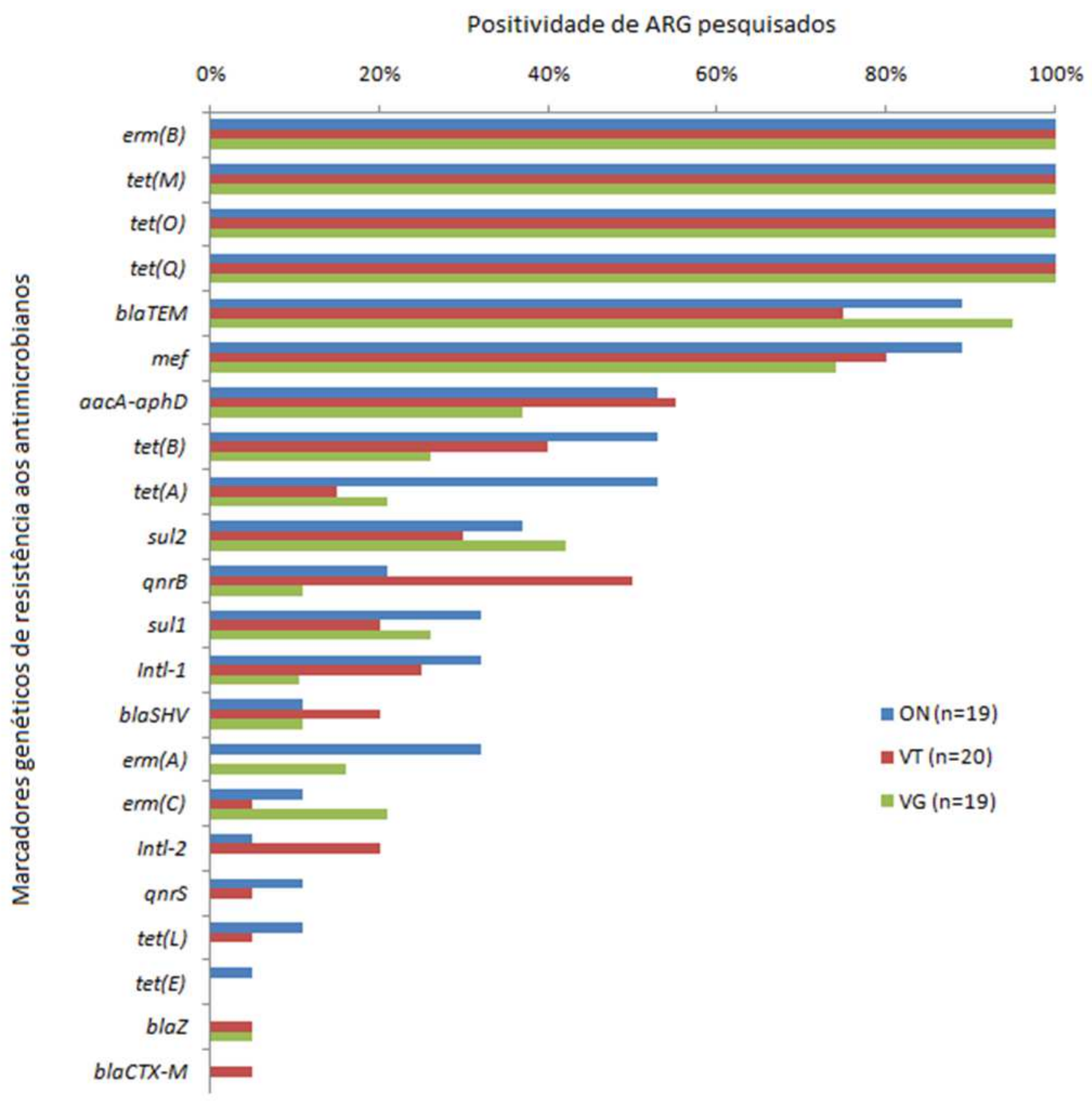


Figura 4. Diagrama de Venn mostrando a distribuição dos determinantes genéticos de resistência detectados entre os grupos de indivíduos onívoros (ON), ovolactovegetarianos (VT) e vegetarianos estritos (VG)

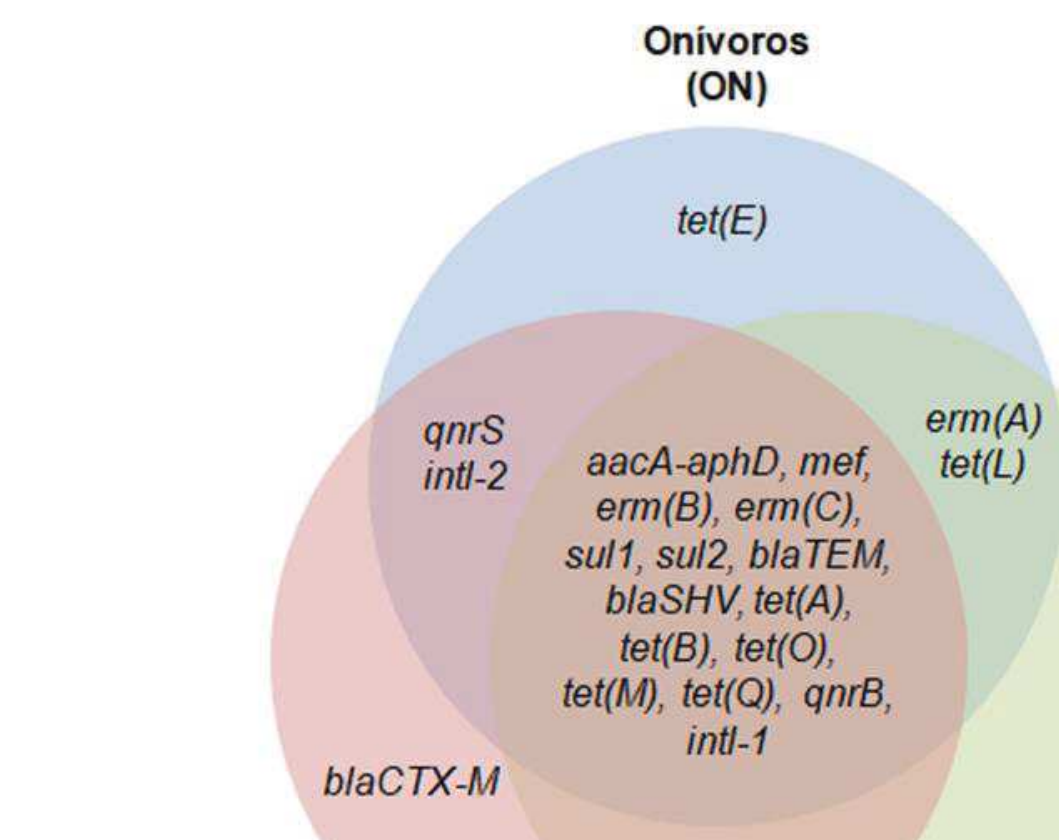

blaZ

Ovolactovegetarianos

(VT)
Vegetarianos estritos

(VG)

De acordo com os dados obtidos a partir da triagem dos ARG entre os três diferentes grupos de indivíduos com hábitos alimentares diferentes, uma distribuição altamente homogênea dos determinantes genéticos detectados foi observada entre os grupos ON, VT e VG. Nenhum agrupamento evidente foi observado pelo dendrograma obtido. Embora tenha sido observada a formação de dois clusters, considerando um limiar entre 65 e 70\% de similaridade, não foi observada diferenciação dentro de cada cluster, considerando os participantes do estudo. Os dados apoiam as observações de que diferentes hábitos alimentares podem não influenciar, em uma visão abrangente, a distribuição de ARG na microbiota intestinal humana (Figura 5). 
Figura 5. Dendrograma mostrando agrupamento de similaridade das amostras de acordo com a presença/ ausência de ARG. Foi utilizado o coeficiente de Dice de similaridade e o método UPGMA (Unweighted Pair Group Method with Arithmetic Averages). Limiar entre 65 a 70\% de similaridade foi considerado

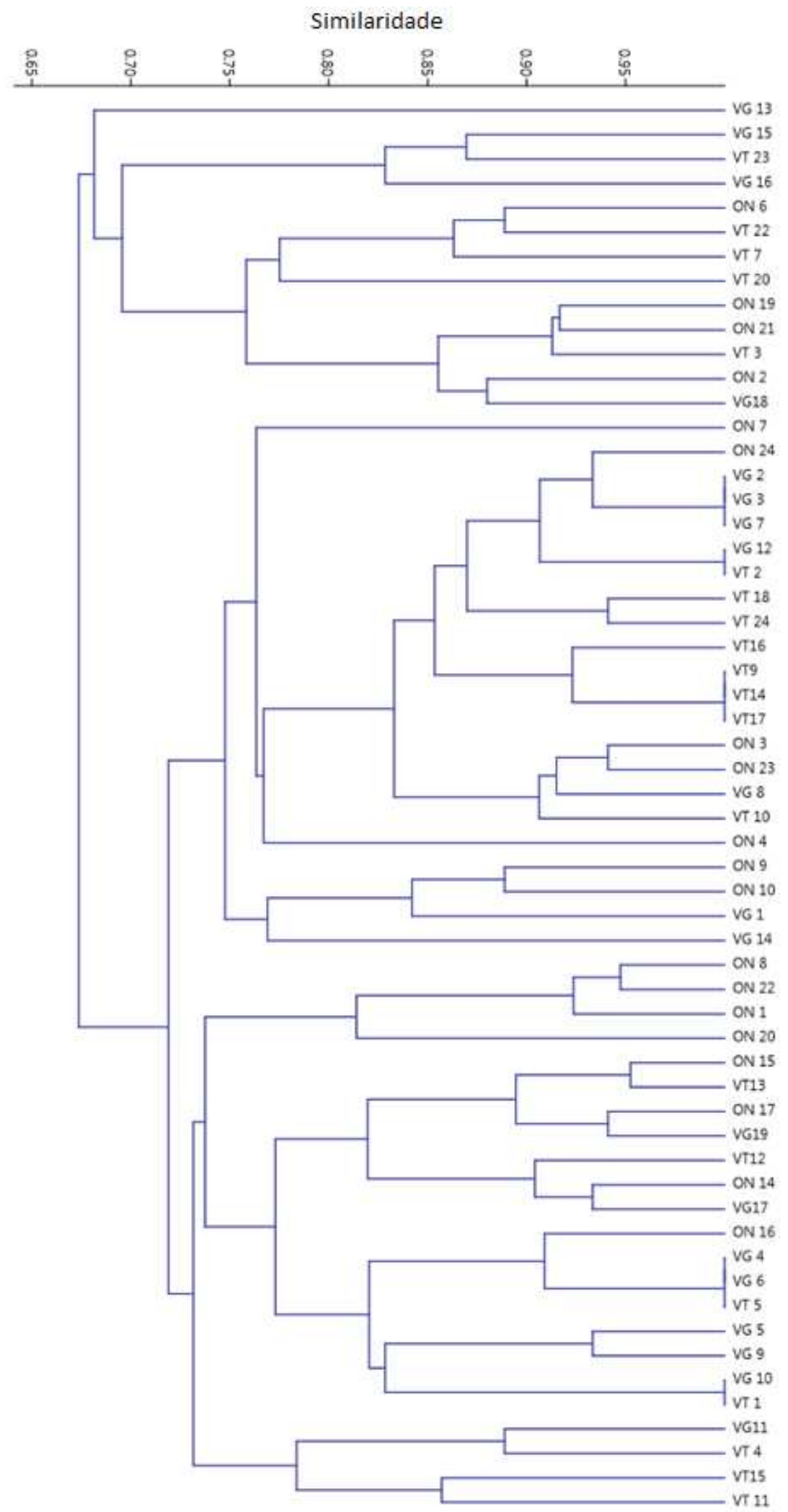




\section{DISCUSSÃO}

Neste estudo não foram observadas diferenças significativas nos dados antropométricos dos participantes, sugerindo que provavelmente os hábitos nutricionais estariam mais relacionados a alterações eventuais no resistoma da microbiota intestinal humana. Considerando um eventual viés relacionado aos grupos étnicos e seu comportamento social, torna-se muito difícil abordar essa discussão, pois a maioria dos participantes pertencia às etnias branca e parda. $\mathrm{O}$ termo "pardo" é particularmente complexo, e é usado no Brasil para se referir a pessoas de ascendência étnica e comportamento social mistos (NOBLES, 2000), daí a dificuldade de determinar e discutir a influência dos grupos étnicos sobre o resistoma. Ainda assim, ao serem consideradas as demais características populacionais, como condição de saúde e ser residente na mesma área urbana, não foram observadas diferenças quanto à etnia. A predominância observada de ingestão de fibras nas dietas de VT e VG, em relação à de ON, pode sugerir que os alimentos com menor grau de processamento, principalmente vegetais, podem ser considerados como a principal fonte de ARG nesses indivíduos, com baixo impacto de alimentos de origem animal no resistoma microbiano. Entretanto, de acordo com a literatura e com a ampla distribuição de ARG observada, é razoável sugerir um intercâmbio entre os microbiomas humano, animal e vegetal, uma vez que os ARG relacionados aos antimicrobianos usados na medicina veterinária foram detectados no resistoma intestinal de indivíduos VG (ARGUDÍN et al., 2017; MILANOVIĆ et al., 2017).

Quanto ao grupo ON, é provável que alimentos de origem animal e vegetal contribuam para a composição de seu resistoma. Em contrapartida, para os grupos VT e VG, considerando que alimentos derivados de animais podem desempenhar um papel menor na microbiota intestinal, é possível que microrganismos associados a vegetais e alimentos minimamente processados sejam a principal fonte de ARG para construir o resistoma intestinal humano. É importante reforçar que os resultados mostraram uma composição final geral semelhante entre os resistomas clínicos intestinais de ON, VT e VG, sendo possível observar uma distribuição homogênea das amostras de voluntários, sem agrupamento relacionado aos hábitos alimentares. Alguns autores afirmam que a composição geral do resistoma não é significativamente afetada pela dieta e sugerem, entretanto, que alimentos derivados 
de carne e animais podem conter mais ARG (LOSASSO et al, 2018b). Vale ressaltar que, nos estudos de Losasso e colaboradores (2018), a localização geográfica é diferente, os critérios de inclusão e exclusão são diferentes e o número de ARG pesquisados foi menor do que em nosso estudo, o que pode explicar a informação não uniforme obtida a partir dos resultados.

À medida que informações científicas e novos conhecimentos são obtidos a respeito da resistência aos antimicrobianos, muitas questões a respeito do fenômeno vão mudando ao longo do tempo. Porém, as interações entre humanos, animais e o meio ambiente neste contexto ainda não foram completamente elucidadas (KIM e CHA, 2021). A localização geográfica e o comportamento mostram grande influência sobre o resistoma intestinal humano e fatores ambientais são aceitos como importantes moduladores da distribuição de microrganismos em ecossistemas diferentes, contemplando a abordagem de Saúde Única. Medidas como políticas de controle do uso de antimicrobianos, densidade populacional, saneamento, higiene e gestão de resíduos têm um impacto expressivo na diversidade da microbiota e na distribuição de ARG, especialmente na microbiota intestinal (FORSLUND et al., 2013; LEE et al., 2020; MILANOVIĆ et al., 2017). Além disso, os resistomas do solo, da água, de plantas e animais mostram um core de genes em comum, indicando que existe uma conexão entre eles e que os ARG podem ser compartilhados (AGGA et al., 2015; ARGUDÍN et al., 2017; PAL et al., 2016).

A frequência e abundância de genes de resistência em um determinado ambiente, incluindo a microbiota intestinal, estão relacionadas com os níveis de impacto antropogênico, de forma que o resistoma responderá à modulação feita por atividades humanas (LEE et al., 2020). Em contrapartida, os ARG podem permanecer de forma estável na microbiota humana por períodos longos, mesmo na ausência da seleção exercida pelo antimicrobiano. Esta permanência também pode ser observada em ambientes que têm pouca ou nenhuma exposição aos antimicrobianos de uso clínico (VERSLUIS et al., 2015). Desta forma, a diversidade de ARG é devida não só ao efeito direto da pressão seletiva exercida pelo uso de antimicrobianos, mas também à transferência de ARG entre os diferentes microbiomas. 
Na produção animal, é comum o tratamento de todo o grupo quando um único animal adoece, especialmente na produção aviária, na qual muitos animais ficam aglomerados em um mesmo espaço. Em aquicultura, onde não é possível tratar apenas um animal, os antimicrobianos são adicionados diretamente na água ou no alimento dos animais. Desta forma, microrganismos destes animais, tanto os saudáveis quanto os doentes, e microrganismos do ambiente ao redor estão frequentemente sendo expostos aos antimicrobianos. As fezes destes animais, resíduos de antimicrobianos, produtos de tratamento de esgoto e água residual chegam ao solo e a ambientes aquáticos (ARGUDÍN et al., 2017). Vários estudos já evidenciaram a importância da contaminação fecal no processo de disseminação de bactérias resistentes e ARG, mostrando a alta detecção de ARG em fezes de animais e de humanos e em resíduos de esgoto e de estações de tratamento de água (LI et al., 2015; KOCZURA et al, 2016; SINGH, VERMA e TANEJA, 2019; ZAHEER et al, 2019). Através do solo e água de irrigação, os ARG alcançam os vegetais (ARGUDÍN et al., 2017).

Os vegetais têm um papel importante na distribuição de ARG, mas pouco destaque é dado ao resistoma de plantas. Seu resistoma compartilha ARG com o ambiente ao redor, e o solo é, provavelmente, a principal fonte de ARG para o resistoma em plantas (ARGUDIN et al, 2017; CHEN et al., 2019). Como são alimentos consumidos crus ou com baixo processamento, maiores são as chances de bactérias resistentes e ARG permanecerem viáveis e chegarem à microbiota humana (CHEN et al., 2019). Além disso, diversos estudos já evidenciaram que vegetais orgânicos apresentam um resistoma mais rico quando comparados aos cultivados de forma convencional, sugerindo que o consumo de vegetais orgânicos também é uma fonte importante de ARG para a microbiota humana (LIN et al. 2019; SU et al., 2015; ZHOU et al., 2017a). Entretanto, existem legislações específicas que dispõem sobre a qualidade microbiológica dos alimentos e determinam os níveis de população microbiana aceitável para que esses alimentos possam ser comercializados (BRASIL, 2019). Isso pode indicar que o tipo e a qualidade microbiológica dos alimentos tenham um impacto mais significativo sobre o conteúdo do resistoma intestinal humano do que a dieta em si.

As tetraciclinas, macrolídeos, $\beta$-lactâmicos e sulfonamidas estão entre os antimicrobianos mais utilizados em animais de criação. Podem ser usados para 
tratamento de infecções, para profilaxia, metafilaxia e, em baixas doses, como promotores de crescimento (SÁNCHEZ-OSUNA et al., 2019; SARMIENTO et al., 2019). O uso de antimicrobianos como promotores de crescimento foi proibido em diversos países, devido ao aumento de resistência a estas drogas em bactérias isoladas destes animais e posterior disseminação para outros ambientes, representando riscos para a saúde humana (ARGUDÍN et al., 2017; DE SOUZA et al., 2016). No Brasil, o uso de vários antimicrobianos como promotores de crescimento foi banido no início dos anos 2000, entretanto o consumo de antimicrobianos permanece alto. Estima-se que no Brasil e nos outros países que compõem o BRICS (Brasil, Rússia, Índia, China e África do Sul), o consumo duplique em atividades de pecuária até o ano de 2030. Apesar da proibição, o uso para profilaxia e metafilaxia permanece alto, já que estas atividades se tornaram intensivas e em larga escala (DE SOUZA et al., 2016; KOIKE et al., 2017).

As tetraciclinas são uma classe de antimicrobianos que têm atividade bacteriostática e apresentam amplo espectro de ação, que inclui anaeróbios e aeróbios Gram-positivos e Gram-negativos, microrganismos intracelulares como Chlamydia sp. e Rickettsia sp. e alguns protozoários. Atuam inibindo a síntese proteica, se ligando de forma reversível à subunidade $30 \mathrm{~S}$ do ribossomo bacteriano (MAROSEVIC, KAEVSKA e JAGLIC, 2017; MOFFA e BROOK, 2015).

O conjunto de genes associados a resistência às tetraciclinas é um dos mais extensos, e são encontrados não só em microrganismos patogênicos, mas também em microrganismos ambientais (MAROSEVIC, KAEVSKA e JAGLIC, 2017). Os principais mecanismos de resistência às tetraciclinas são através de bombas de efluxo e proteção ribossomal. Outros mecanismos como inativação enzimática e modificação de sítio-alvo também podem ocorrer, porém são menos frequentes. As bombas de efluxo de tetraciclinas são proteínas que fazem parte de um grupo de transportadores integrais de membrana conhecido como superfamília de facilitadores principais (major facilitator superfamily - MFS) e atuam na exportação de tetraciclinas em um processo dependente de energia. As tetraciclinas de segunda e terceira geração (doxitetraciclina, minociclina e tigeciclina) não sofrem ação destas bombas de efluxo. Já as proteínas de proteção ribossomal (RPP) atuam interagindo com o ribossomo e enfraquecendo a ligação entre as tetraciclinas e seu sítio-alvo. A tigeciclina, devido a sua maior afinidade com o sítio-alvo no ribossomo, mantém sua 
atividade. Os genes tet(O) e tet(M) são os genes mais prevalentes dentre os genes que codificam RPP. (MOFFA e BROOK, 2015; THAKER, SPANOGIANNOPOULOS e WRIGHT, 2010).

Há evidências de que os genes tet(Q) e tet(O) são muito abundantes nas fezes de animais criados para consumo. Segundo Kyselková e colaboradores (2015) os genes tet( $Q)$, tet $(O)$ e $\operatorname{tet}(W)$ se mostram como parte estável do resistoma intestinal do gado, e estes genes de resistência às tetraciclinas podem ser introduzidos em solos de pastagem, podendo persistir no solo por longos períodos (KYSELKOVÁ et al., 2015; ZAHEER et al., 2019). Estes genes também se mostraram abundantes em indivíduos de diversos países, indicando que tet(Q) e tet(O) estão presentes em abundância na microbiota intestinal de seres humanos e animais para consumo. Os genes de resistência às tetraciclinas também são abundantes no metagenoma intestinal humano em diversos países (SINGH, VERMA E TANEJA, 2019). Nos estudos de Hu e colaboradores (2013), os genes tet(Q), tet $(O)$ e $\operatorname{erm}(B)$ estavam entre os 10 genes de resistência mais abundantes entre os indivíduos na China, Espanha e Dinamarca. Mais recentemente, Feng e colaboradores (2018), ao avaliarem amostras de fezes de 180 indivíduos oriundos de 11 países diferentes, observaram a presença do gene tet(M) em todas as amostras analisadas, sugerindo sua ocorrência comum na microbiota intestinal humana.

O gene tet(Q) tem alta prevalência entre isolados de Bacteroides sp. Estimase que aproximadamente $80 \%$ dos isolados de Bacteroides sp. possam carrear o gene tet(Q) em seu genoma (NARIMANI et al., 2016; WEXLER, 2007). É possível que esse fato contribua para a alta prevalência do gene tet(Q) no metagenoma intestinal humano, já que microrganismos do gênero Bacteroides sp. são membros da microbiota intestinal em altos níveis populacionais, especialmente nas partes distais do trato gastrintestinal, o que seria muito representativo em espécimes fecais. Este gene, juntamente com genes erm, são comumente encontrados em pessoas clinicamente saudáveis independentemente do tipo de dieta ou condição cultural e mostram homologia de mais de 90\% com genes de diferentes espécies, incluindo espécies não encontradas no intestino, indicando disseminação por transferência horizontal (NARIMANI et al., 2016; NIESTĘPSKI et al., 2019; SARKAR et al, 2015; WEXLER, 2007). 
Os genes tet estão comumente associados a transposons e elementos genéticos móveis, havendo uma variedade de transposons descritos na literatura que carreiam genes tet e contribuem para sua ampla distribuição entre os ambientes. Uma família de transposons, conhecida como Tn916, comumente carreia genes $\operatorname{tet}(M)$. $O$ transposon $\operatorname{Tn} 1545$ carreia os genes tet( $M)$ e erm(B), enquanto o transposon CTnDOT, os quais são grandes transposons conjugativos comumente presentes em Bacteroides sp., carreiam os genes $\operatorname{tet}(Q)$, tet $(X)$ e os genes erm(B), $\operatorname{erm}(F)$ e erm(G). Além destes, uma série de outros transposons que contêm genes tet, como tet(M), tet( $Q$ ) e tet(O), já foram descritos (MAROSEVIC, KAEVSKA e JAGLIC, 2017; NARIMANI et al., 2016).

Estudos envolvendo a análise de resistomas de amostras ancestrais mostram evidências da presença de genes de resistência primitivos. Genes relacionados à resistência às tetraciclinas e outros antimicrobianos já foram identificados em amostras oriundas de múmias pré-Inca/Inca, múmias italianas, andinas e amostras ancestrais de sedimentos de solo. A presença de formas primitivas de genes de resistência às tetraciclinas em amostras datadas de muito tempo antes da era da antibioticoterapia pode ajudar a esclarecer a possível origem destes genes. Os genes de resistência às tetraciclinas têm ampla distribuição, sendo encontrado em praticamente todos os ambientes, e são abundantes na microbiota intestinal humana. Em contrapartida, a pressão seletiva pelo uso de tetraciclinas não explica isoladamente esta alta prevalência e distribuição. É provável que estes genes expressassem produtos com outras funções, não necessariamente relacionados à resistência, como sinalização, comunicação celular ou transporte. Posteriormente, a introdução do uso de tetraciclinas pode ter permitido a evolução e diversificação destas formas ancestrais dos genes de resistência às tetraciclinas, contribuindo para sua ampla distribuição. Além disso, é possível que metais pesados e antimicrobianos do grupo MLS atuem na co-seleção de resistência às tetraciclinas (SANTIAGO-RODRIGUEZ et al., 2015; SANTIAGO-RODRIGUEZ et al., 2018; SINGH, VERMA e TANEJA, 2019)

O grupo MLS é composto por antimicrobianos das classes dos macrolídeos, lincosamidas e estreptograminas. Os macrolídeos são representados pela eritromicina, azitromicina, claritromicina e outros. Na classe das lincosamidas estão a clindamicina e lincomicina, e as estreptograminas envolvem a quinupristina 
(estreptogramina B) e dalfopristina (estreptogramina A). Embora sejam quimicamente diferentes, as três classes apresentam mecanismo de ação semelhantes, atuando na unidade $50 S$ do ribossomo bacteriano e inibindo a síntese proteica (CATTOIR, 2016; ROBERTS, 2011).

Os genes de resistência ao grupo MLS, quando expressos, podem conferir resistência a um ou mais antimicrobianos deste grupo. A maioria destes genes codifica principalmente: (i) enzimas rRNA metilases, as quais são codificadas pelos genes erm e conferem resistência às três classes do grupo MLS; (ii) bombas de efluxo, codificadas pelos genes mef e msr. Os genes mef conferem resistência apenas a macrolídeos, e os genes $\mathrm{msr}$ a macrolídeos e estreptogramina B; e (iii) enzimas de inativação, codificadas por vários genes, dentre eles os genes ere, que codificam esterases que hidrolisam o antimicrobiano e impedem sua ligação ao ribossomo (CATTOIR, 2016; MAROSEVIC, KAEVSKA e JAGLIC, 2017; ROBERTS, 2011).

Dentre os genes erm, o gene erm(B) é o mais frequente e comumente carreado, podendo estar presente no genoma de Gram-negativos, Gram positivos, anaeróbios e aeróbios. O gene $\operatorname{erm}(B)$ e a maioria dos genes de resistência ao grupo MLS estão frequentemente associados a elementos genéticos móveis, com destaque para transposons e plasmídeos, e é comum o gene erm(B) estar presente nos mesmos elementos que os genes tet, principalmente tet(M). Já os genes mef são os mais prevalentes dentre os genes que codificam bombas de efluxo, também são encontrados em diversos microrganismos e estão associados de forma frequente a transposons e elementos genéticos móveis, favorecendo sua transferência horizontal (CATTOIR, 2016; FEßLER, 2018; ROBERTS, 2011).

Como descrito pelos estudos de Hu e colaboradores (2013), o gene erm(B) estava entre os genes de resistência mais abundantes entre os indivíduos da China, Espanha e Dinamarca. Outros estudos encontraram resultados semelhantes, evidenciando que genes de resistência ao grupo MLS são abundantes e frequentes na microbiota de humanos e animais, além de serem comumente encontrados em diversos outros ambientes, como solo, água e esgoto (FENG et al., 2018; LI et al., 2015; PAL et al., 2016). 
Há evidências de que a abundância de determinados grupos de genes de resistência está diretamente relacionada com os níveis de impacto antropogênico nestes ambientes (LI et al., 2015). Desta forma, diversos estudos demonstraram que os genes mais abundantes e amplamente distribuídos entre os ambientes são os genes associados à resistência às tetraciclinas, ao grupo MLS, $\beta$-lactâmicos (com destaque para o gene blaTEM), sulfonamidas, aminoglicosídeos e quinolonas (HU et al., 2013; FENG et al., 2018; FORSLUND et al., 2013; LI et al., 2015; PAL et al., 2016) .

De acordo com Feng e colaboradores (2018) os genes de resistência às tetraciclinas, grupo MLS, $\beta$-lactâmicos e aminoglicosídeos são bastante abundantes na microbiota intestinal humana, sendo que os genes MLS e tet foram considerados ubíquos (presentes em mais de $60 \%$ das amostras) entre os indivíduos de onze países diferentes.

Os $\beta$-lactâmicos foram os primeiros antimicrobianos a serem descobertos e são amplamente utilizados na medicina humana e veterinária. Atuam inibindo a síntese da parede celular bacteriana e é uma classe composta por 4 grupos: as penicilinas, cefalosporinas, monobactâmicos e carbapenêmicos. Dentre os mecanismos de resistência existentes, a produção de enzimas $\beta$-lactamases é o mais comum. Mais de $500 \beta$-lactamases já foram identificadas e os genes que codificam para estas enzimas podem ser plasmidiais ou cromossômicos. Uma grande variedade de microrganismos já foi descrita carreando estes genes, mas são mais comuns em bactérias Gram-negativas. As $\beta$-lactamases de espectro estendido (ESBL) são enzimas capazes de hidrolisar penicilinas, cefalosporinas de $1^{\text {a }}$ a $4^{a}$ geração e monobactâmicos, mas não têm ação sobre carbapenêmicos e cefamicinas e sofrem ação dos inibidores de $\beta$-lactamases, como o ácido clavulânico (ALI et al., 2018; SHAIKH et al., 2015).

Os genes blateM, blashv e blactX-M codificam as enzimas TEM, SHV e CTX-M, respectivamente. Estas enzimas são as ESBL mais comuns. Dentre estas, as enzimas CTX-M são as enzimas mais recentemente descritas e são consideradas as mais eficazes em relação à facilidade de transferência horizontal de seus genes e disseminação, se tornando abundantes em uma variedade de ambientes e, superando, em muitos casos, outras enzimas, como as enzimas TEM. São 
associadas a elementos genéticos móveis, principalmente plasmídeos, e a expressão dos genes blaстХ-м costuma estar associada à co-resistência. São encontradas em muitas bactérias da família Enterobacteriaceae, e têm sua origem em espécies do gênero Kluyvera sp., os quais são microrganismos ambientais, mas que podem ser patógenos oportunistas (ALI et al., 2018; SHAIKH et al., 2015).

As enzimas do tipo TEM são predominantes em bactérias Gram-negativas da família Enterobacteriaceae, com destaque para E. coli e Klebsiella pneumoniae. Estima-se que a maior parte da resistência a ampicilina em Gram-negativos seja devida às enzimas TEM. Diferentemente das CTX-M, estas enzimas têm origem devido a processos de mutação, e existem mais de 200 variantes descritas. A primeira enzima TEM descoberta, TEM-1, e sua variante subsequente, TEM-2, têm atividade frente a penicilinas e cefalosporinas de $1^{a}$ geração, sendo consideradas, portanto, variantes com atividade não-ESBL. As variantes seguintes já apresentavam atividade de ESBL. As enzimas SHV são mais frequentemente encontradas em bactérias do gênero Klebsiella sp. e são prevalentes em isolados clínicos. É comum os genes blashv estarem associados a plasmídeos, e as enzimas SHV têm menos variantes quando comparadas com TEM e CTX-M (ALI et al., 2018; GHAFOURIAN et al., 2015).

O gene blatem foi o mais frequentemente encontrado dentre os genes que codificam para enzimas ESBL, enquanto o gene blactX-M foi detectado em apenas uma amostra do grupo de indivíduos ovolactovegetarianos. Alguns estudos encontraram resultados semelhantes, com predominância de genes blaTEM em amostras de carne, leite e queijo (TEKINER e ÖZPINAR, 2016) e em amostras de água residuais de estações de tratamento de esgoto (ZIELIŃSKI et al., 2019), com detecção de blateM em todas as amostras, incluindo nas amostras de água já tratadas. Água e alimentos são disseminadores destes determinantes de resistência, fazendo-os alcançar outros ambientes e justificando sua presença na microbiota intestinal humana e de animais. Os genes blaTEM, juntamente com genes de resistência à macrolídeos, aminoglicosídeos e tetraciclinas, segundo Pal e colaboradores (2016), são genes que podem ser considerados como tendo distribuição generalizada entre os ambientes, sendo frequente a sua detecção. 
Em contrapartida, uma série de outros estudos encontrou resultados divergentes. Losasso e colaboradores (2018b) observaram baixa frequência de detecção de genes blatEM. Outros trabalhos detectaram os genes blactX-м e suas variantes como os mais frequentes em amostras fecais de humanos, animais (ISEPPI et al., 2020; MAHAMAT et al., 2019; VAN DEN BUNT et al., 2018) e alimentos (DAY et al., 2019; SCHILL et al., 2017). Estas observações estão em consonância com a conhecida facilidade de disseminação e abundância dos genes blactX-м em diversos ambientes (RAHMAN et al., 2018). Além disso, as enzimas CTX-M são bastante abundantes e predominantes na América Latina e no Brasil (CANTÓN, GONZÁLEZ-ALBA e GALÁN, 2012; SILVA e LINCOPAN, 2012; TEKINER e ÖZPINAR, 2016).

A baixa detecção de blactx-M observada neste estudo levanta algumas considerações. A prevalência de genes de resistência circulantes em um determinado ambiente sofre impacto direto de características, como taxa de uso de antimicrobianos, taxa de infecções por bactérias produtoras de ESBL, mortalidade, viagens ao exterior e local de residência, por exemplo (DAY et al., 2019; BENGTSSON-PALME et al., 2015). Estes fatores influenciam o carreamento dos genes entre os microrganismos no ambiente, portanto, é possível que estes resultados representem uma característica local, e, devido ao número reduzido de amostras, não seja possível extrapolar os resultados. O estudo de Sarmiento e colaboradores (2019), realizado em voluntários eutróficos, com sobrepeso e obesos, na mesma localidade do presente trabalho, também mostrou alta frequência de detecção do gene blatEM no resistoma intestinal desses indivíduos, sugerindo que este gene provavelmente é comum na microbiota intestinal das pessoas da região.

Apesar dessa diferença, independente de qual gene em específico seja detectado, a identificação frequente de genes que codificam enzimas ESBL em diversos ambientes sinaliza um alerta. A presença frequente destes genes também torna maior a possibilidade de expressar o fenótipo ESBL. Desta forma, a maior circulação de bactérias que carreiam genes codificadores de ESBL pode representar uma barreira adicional para o tratamento bem sucedido de infecções causadas por estes microrganismos. 
Os genes AmpC, blaKPC, blasPM-1, blaoXA-23 e blaoXA-51 não foram detectados em nenhuma das amostras analisadas, e outros estudos também não detectaram estes genes com frequência na microbiota intestinal humana.

As enzimas AmpC são $\beta$-lactamases e estão presentes principalmente em bactérias Gram-negativas. No geral, são capazes de conferir resistência às penicilinas, cefalosporinas de $1^{a}$ a $3^{a}$ geração, incluindo as cefamicinas, e monobactâmicos, não sofrendo ação dos inibidores de $\beta$-lactamases, diferentemente das enzimas ESBL. Os genes que codificam enzimas AmpC podem ser cromossômicos ou plasmidiais e sua expressão pode ser constitutiva ou induzível. Boa parte dos genes cromossômicos que codificam AmpC tem expressão induzível. Neste tipo de expressão, alguns $\beta$-lactâmicos atuam como agentes indutores, os quais irão induzir a expressão do gene. Em contrapartida, na expressão constitutiva, os genes serão expressos sem a regulação de um agente indutor. Os genes plasmidiais que codificam AmpC têm, em sua maioria, expressão constitutiva (MEINI et al., 2019).

Bactérias que tem genes cromossômicos de expressão induzível representam uma dificuldade para o tratamento e para reportar os resultados de testes de susceptibilidade, uma vez que uma sensibilidade observada in vitro pode não ser observada no momento do tratamento do paciente. Existe um grupo de microrganismos conhecido como grupo CESPM (Citrobacter freundii; Enterobacter spp., Serratia marcescens, Providencia stuartii e Morganella morganii) que tem importância clínica, pois frequentemente podem apresentar este perfil. Já as que carreiam genes de expressão constitutiva, apresentam o fenótico clássico de AmpC (MEINI et al., 2019).

Outros estudos também observaram uma menor prevalência de genes ampC em amostras não clínicas (SCHILL et al., 2017; TEKINER e ÖZPINAR, 2016). Segundo De Lastours e colaboradores (2018), o impacto do uso de $\beta$-lactâmicos, como ceftriaxona, teria um efeito mais significativo sobre a microbiota intestinal humana em selecionar enterobactérias produtoras de $A m p C$ do que um efeito de disseminação interindividual destes microrganismos. Ao contrário do que se sugere para enzimas ESBL, cujo surgimento estaria relacionado a uma transmissão cruzada, o uso do antimicrobiano parece ter mais impacto no caso das enzimas 
AmpC. Isso talvez seja um dos motivos para que haja uma maior distribuição de enzimas do tipo ESBL do que AmpC.

As carbapenemases pertencentes à classe $\mathrm{A}$ de Ambler apresentam serina em seu sítio alvo, e são enzimas encontradas predominantemente em enterobactérias. As enzimas KPC são as mais prevalentes mundialmente dentre as carbapenemases de classe A e apresentam ação contra todos os grupos de $\beta$ lactâmicos, sendo parcialmente inibidas por inibidores de $\beta$-lactamases. Os genes blakPC são majoritariamente plasmidiais, e embora já tenham sido encontrados em outras bactérias Gram-negativas, permanecem predominantes em K. pneumoniae (ESCADÓN-VARGAS et al., 2017).

As carbapenemases de classe B se caracterizam por apresentar um íon metálico em seu sítio ativo, usualmente o zinco, e são conhecidas como metalo- $\beta$ lactamases. São inibidas por quelantes metálicos e mostram atividade frente às penicilinas, cefalosporinas e carbapenêmicos, permanecendo susceptíveis apenas aos monobactâmicos. As enzimas SPM são carbapenemases de classe B associadas a plasmídeos, e os genes que codificam estas enzimas tem apenas uma variante, blasPM-1. Inicialmente, essas enzimas foram detectadas no ano de 2001, em um isolado de Pseudomonas aeruginosa, na cidade de São Paulo, Brasil, fato que deu o nome SPM à enzima: São Paulo metalo- $\beta$-lactamase. Até o ano de 2007, não haviam relatos de SPM detectadas fora do Brasil, e o porquê de sua epidemiologia ser mais restrita ao país não é muito claro (ESCADÓN-VARGAS et al., 2017).

As carbapenemases de classe D, também conhecidas como oxacilinases, são enzimas que conferem resistência às penicilinas, cefalosporinas e monobactâmicos, e não sofrem ação de inibidores de $\beta$-lactamases. Há um subgrupo de oxacilinases que apresenta atividade frente aos carbapenêmicos, mas uma atividade que é variável e menos eficiente quando comparada com a de outras carbapenemases. A enzima OXA-51 é codificada pelos genes blaoXA-51, que são cromossômicos e tipicamente presentes em bactérias do complexo Acinetobacter baumannii, sendo intrínsecas a estes microrganismos. Existem muitas variantes dos genes cromossômicos blaoxA-51, o que indica que o uso de antimicrobianos tem exercido uma intensa pressão seletiva sobre as bactérias do complexo Acinetobacter baumannii. Já as enzimas OXA-23 são codificadas pelos genes blaoXA-23, os quais 
são principalmente mediados por plasmídeos. São isoladas principalmente em bactérias do gênero Acinetobacter sp., mas já foram descritas em espécies não $A$. baumannii e raramente em representantes da família Enterobacteriaceae. O primeiro relato na América Latina ocorreu no Brasil, e têm uma alta disseminação entre os isolados $A$. baumannii no país (ESCADÓN-VARGAS et al., 2017; LOGAN e WEINSTEIN, 2017).

Os genes blaZ e mecA não figuram entre os genes detectados com frequência na microbiota intestinal humana. O gene blaZ codifica enzimas $\beta$ lactamases do tipo penicilinases, e é encontrado principalmente em Staphylococcus $s p$. Existem quatro tipos de penicilinases codificadas pelo gene blaZ: as penicilinases $A, C$ e $D$, as quais são codificadas por genes cromossômicos, e a penicilinase $B$, que é plasmídeo mediada. As bactérias produtoras destas enzimas apresentam resistência às penicilinas, com exceção das penicilinas penicilinaseresistentes, como a meticilina e oxacilina. Também permanecem susceptíveis às cefalosporinas, monobactâmicos, carbapenêmicos e sofrem ação dos inibidores de $\beta$-lactamases. A maioria dos isolados de Staphylococcus sp. apresenta resistência às penicilinas (FERREIRA et al., 2017).

O gene mecA codifica uma proteína ligadora de penicilina modificada, a PBP2a, que tem afinidade reduzida por $\beta$-lactâmicos. Este gene se encontra em um cassete cromossômico, conhecido como SCCmec, e pode ser transferido horizontalmente, sendo prevalente em Staphylococcus sp. Bactérias que expressam este gene apresentam resistência a todos os $\beta$-lactâmicos, com exceção de algumas cefalosporinas mais recentes, como a ceftarolina (FERREIRA et al., 2017; ROCCHETTI et al., 2018).

As sulfonamidas são antimicrobianos sintéticos, bacteriostáticos e inibidores competitivos da enzima dihidropteroatosintase. Esta enzima converte o ácido paraamino benzoico (PABA) em dihidropteroato, que é um precursor do folato. Ao inibirem a síntese de folato, interferem na síntese de DNA e RNA na célula bacteriana. As sulfonamidas têm atividade antimicrobiana contra um espectro amplo de microrganismos e são usadas na medicina humana e animal. Algumas sulfonamidas mostram ação antiprotozoário e antifúngica, enquanto outras são usadas também como herbicidas. Em isolados clínicos, a resistência mediada por 
genes sul plasmidiais é a mais comum. Estes genes codificam proteínas com baixa afinidade pelas sulfonamidas. Existem 4 variantes de genes sul, sendo sul1 e sul2 os mais comuns. Os genes sul1 são tipicamente associados a integrons de classe 1 , e os genes sul2 estão comumente localizados em plasmídeos (ADESOJI, OGUNJOBI e OLATOYE 2016; SÁNCHEZ-OSUNA et al., 2019).

Os genes sul1 e sul2 foram detectados em amostras pertencentes aos três grupos, e o gene sul2 foi o mais comum no presente estudo. Existem evidências da presença de genes sul em diversos ambientes, como água, rios (ADESOJI, OGUNJOBI e OLATOYE, 2016; KOCZURA et al., 2016), solo (ZHOU et al., 2017b), fezes de humanos e animais (MACHADO et al., 2013; MU et al., 2015), carnes de animais para consumo, alimentos, plantas (BARAN et al., 2011; DE PAULA et al., 2018) e esgoto (NAQUIN et al., 2017), mostrando a ampla distribuição e mobilização destes genes. As sulfonamidas, junto com as tetraciclinas e penicilinas, são um dos grupos de antimicrobianos mais utilizados para o tratamento de animais de criação para consumo, como gado, porcos e frangos. Além disso, as sulfonamidas mostraram alta persistência em ambientes como solo, sedimentos e água, devido a algumas características, como alta taxa de penetração nos solos, alta mobilidade e baixa eficiência de remoção. Estas características associadas ao seu uso frequente na agricultura, aquicultura e criação de animais contribuem e justificam sua distribuição entre os ambientes, incluindo o trato intestinal humano (MACHADO et al., 2013; MU et al. 2015; SÁNCHEZ-OSUNA et al., 2019).

As quinolonas também são antimicrobianos sintéticos, desenvolvidos no início da década de 60 com a introdução do ácido nalidíxico. Já na década de 80 , com a adição de um átomo de flúor no anel quinolônico na posição 6 , surgiram as fluoroquinolonas, como a ciprofloxacina, por exemplo. Atuam inibindo as enzimas DNA girase e topoisomerase IV, impedindo a transcrição e replicação do DNA bacteriano. Têm boa atividade contra aeróbios Gram-negativos, atividade intermediária contra alguns Gram-positivos e pouca ou nenhuma atividade em bactérias anaeróbicas, Streptococcus spp. e Enterococcus spp. (ANVISA, 2019; PHAM, ZIORA e BLASKOVICH; 2019).

A resistência às quinolonas surgiu inicialmente devido a mutações cromossômicas, com posterior surgimento dos genes qnr, os quais são plasmídeo 
mediados. O mecanismo de resistência às quinolonas mais comum são as mutações cromossômicas, nas quais ocorre mutação nos genes que codificam as enzimas DNA girase e/ou topoisomerase. Mutações cromossômicas em genes de proteínas regulatórias e bombas de efluxo também são frequentes. Os genes de resistência às quinolonas mediados por plasmídeos são representados principalmente pelos genes qnr, que têm provável origem de bactérias aquáticas. As proteínas qnr protegem as enzimas alvo da inibição pelas quinolonas. Estes genes conferem níveis de resistência mais baixos quando comparados aos genes cromossômicos, porém conferem maior facilidade de transferência horizontal e permitem o carreamento de mais de um gene no mesmo elemento genético móvel (CARUSO et al., 2018; CHENIA, 2016; PHAM, ZIORA e BLASKOVICH; 2019).

Os genes qnrB foram encontrados entre os três grupos, com prevalência entre indivíduos ovolactovegetarianos. Já os genes qnrS foram encontrados apenas entre indivíduos dos grupos onívoros e ovolactovegetarianos, não sendo observados no grupo de vegetarianos estritos. Os genes de resistência às quinolonas já foram descritos em alguns ambientes, como animais para consumo (CARUSO et al., 2018), ambientes aquáticos (CHENIA, 2016) e em seres humanos (FITZPATRICK e WALSH, 2016). Embora tenham distribuição por diversos ambientes, não parecem estar entre os genes predominantes. Estudos como os de Caruso e colaboradores (2018) demonstraram que, embora o fenótipo de resistência às quinolonas tenha sido elevado entre os isolados, a detecção de genes qnr foi muito menor, indicando que os maiores responsáveis pelo fenótipo de resistência observado foram os genes de resistência cromossômicos, sendo os genes qnr responsáveis por apenas uma parcela deste fenótipo. Portanto, é possível que situação semelhante ocorra em outros tipos de amostras, como as do presente estudo.

Os aminoglicosídeos são antimicrobianos bactericidas com amplo espectro de ação, tendo boa atividade contra aeróbios Gram-negativos, Gram-positivos e também contra micobactérias. Atuam inibindo a síntese proteica, através da ligação à subunidade $30 \mathrm{~S}$ do ribossomo bacteriano. São antimicrobianos pouco absorvíveis por via oral, e geralmente são usados em esquemas terapêuticos de infecções mais graves. Em contrapartida, são bastante utilizados para tratamento na medicina veterinária. Dentre os representantes mais utilizados de aminoglicosídeo, estão a estreptomicina, gentamicina e amicacina (ANVISA, 2019; SERIO et al., 2017). 
O mecanismo mais comum de resistência aos aminoglicosídeos é através de modificação enzimática, e existem três classes destas enzimas: as aminoglicosídeo nucleotidiltrasferases (ANT), as aminoglicosídeo fosfotransferases (APH) e as aminoglicosídeo acetiltransferases (AAC). A enzima codificada pelo gene aacA$a p h D$, o qual é mais conhecido como aac(6')-le/aph(2")-la, é bifuncional, apresentando as atividades de acetiltransferase e fosfotransferase. Esta enzima é mais comumente encontrada em bactérias Gram-positivas, embora também possa estar presente em Gram-negativas, e confere resistência à maioria dos aminoglicosídeos (SERIO et al., 2017).

O gene aacA-aphD foi o gene de resistência aos aminoglicosídeos pesquisado, sendo detectado nos três grupos deste estudo. Embora outros trabalhos tenham pesquisado e detectado outros genes de resistência a aminoglicosídeos mais frequentemente que o gene aacA-aphD, genes de resistência aos aminoglicosídeos já foram descritos em ambientes diversos e estão entre os mais abundantes entre a microbiota intestinal (DUAN et al., 2020; RESENDE et al., 2018; LEE et al., 2020; PAL et al., 2016). Assim como outros antimicrobianos, seu uso em humanos e também na medicina veterinária e indústria de alimentos contribui para uma maior frequência de detecção destes genes.

As bombas de efluxo do tipo Mex são bombas multidroga pertencentes à família RND de bombas de efluxo (resistance-nodulation/ cell-division). A maioria de seus operons são cromossômicos e codificam um sistema de efluxo composto por 3 componentes: um transportador associado a membrana citoplasmática (MexB, MexD, MexF e MexY), uma proteína periplasmática de fusão (MexA, MexC, MexE e MexX) e uma proteína de membrana externa formadora de canal (OprM, OprJ e OprN) (LI e PLESIAT, 2016; POONSUK et al., 2014). O sistema de efluxo Mex é um dos principais responsáveis por conferir o fenótipo de multirresistência em $P$. aeruginosa. Isso talvez explique a não detecção de genes mex nas amostras analisadas, uma vez que sua presença é mais frequentemente observada em isolados clínicos (AFKHAMl et al, 2020; MAKAYA et al., 2017; POURAKBARI et al., 2016).

Os ARG estão frequentemente presentes em elementos genéticos móveis, e dentre os integrons, os integrons de classes 1, 2 e 3 são os mais comumente 
associados com ARG e sua disseminação (CAMBRAY et al., 2010; DENG et al., 2015). Neste estudo, genes intl-1, que codificam integrons de classe 1, foram mais detectados, porém com uma frequência intermediária, quando comparado aos outros determinantes. Já o gene intl-2 foi detectado em baixa frequência, estando presentes apenas nas amostras de onívoros e ovolactovegetarianos. Estes resultados sugerem que embora os integrons tenham um papel importante na disseminação de ARG por transferência horizontal, outros elementos móveis, como transposons e plasmídeos, também contribuam para tranferência de ARG na microbiota intestinal humana.

\section{CONSIDERAÇÕES FINAIS}

As atividades humanas têm forte impacto sobre os microbiomas em diferentes ambientes. O uso generalizado de antimicrobianos em humanos, animais e na produção de alimentos, associado à transferência horizontal de genes, permitiu a ampla distribuição de $A R G$, os quais estão presentes em praticamente todos os ambientes. Os alimentos são uma fonte importante de ARG para a microbiota intestinal humana, mas existem muitas variáveis que também podem contribuir para o conteúdo do resistoma intestinal humano, de forma que seus determinantes ainda não estão totalmente claros.

De acordo com uma perspectiva One Health, embora o consumo de vegetais e alimentos pouco processados seja considerado o comportamento mais comum na população amostrada, as fontes de ARG ainda podem variar entre diferentes indivíduos. A distribuição de ARG no ambiente parece ser tão preocupante e disseminada que os hábitos alimentares não são a única fonte de elementos genéticos e pressões seletivas que podem impactar o resistoma intestinal humano. Novos estudos contribuirão para um melhor entendimento do fenômendo da resistência bacteriana aos antimicrobianos e para fornecer subsídios para a implementação de políticas públicas e ambientais que auxiliem no controle deste fenômeno. 


\section{CONCLUSÕES}

- Considerando indivíduos eutróficos, as dietas ovolactovegetariana e vegetariana estrita são mais ricas em fibras e carboidratos, enquanto a dieta onívora apresenta maior ingestão de proteínas.

- O DNA metagenômico extraído de amostras fecais permitiu boa análise e detecção dos determinantes genéticos de resistência, possibilitando o estudo do resistoma intestinal humano.

- Existe um núcleo comum de determinantes de resistência aos antimicrobianos que é compartilhado entre os indivíduos, estando amplamente distribuídos, ainda que estes indivíduos tenham hábitos alimentares diferentes.

- De forma geral, vegetais e alimentos minimamente processados estão altamente relacionados ao resistoma clínico intestinal humano. 


\section{REFERÊNCIAS}

AARTS, H.; MARGOLLES, A. Antibiotic resistance genes in food and gut (nonpathogenic) bacteria.Bad genes in good bugs. Front. Microbiol. v. 5, p. 754, 2015.

ABRIOUEL, $H$. et al. Antibiotic resistance profile of microbes from traditional fermented foods. In: Fermented foods in health and disease prevention. Academic Press, p. 675-704, 2017.

ADDOS, S. A.; SHUBBAR, E. E.; HINDI, A. K. Molecular Study on Distrbution of Sul1 and Sul-2 genes among Salmonella enterica causing Enteric Fever. Al-Kufa Uni. J. Biol. v. 5, n. 2, p. 52-58, 2013.

ADESOJI, A. T.; OGUNJOBI, A. A.; OLATOYE, I. O. Characterization of integrons and sulfonamide resistance genes among bacteria from drinking water distribution systems in southwestern Nigeria. Chemotherapy, v. 62, n. 1, p. 34-42, 2017.

AFKHAMI, H. et al. Antibiotic resistance patterns of efflux pumps MexAB-Opr M in pathogenic Pseudomonas aeruginosa isolates. 2020.

AGGA, G. E. et al. Antimicrobial-resistant bacterial populations and antimicrobial resistance genes obtained from environments impacted by livestock and municipal waste. PLoS One, v. 10, n. 7, p. e0132586, 2015.

ALI, T. et al. The growing genetic and functional diversity of extended spectrum betalactamases. BioMed Res. Int., v. 2018, 2018.

ALLEN, H. K. et al. Call of the wild: antibiotic resistance genes in natural environments. Nat. Rev. Microbiol. v. 8, n. 4, p. 251-259, 2010.

ALMASAUDI, S. B. Acinetobacter spp. as nosocomial pathogens: Epidemiology and resistance features. Saudi J. Biol. Sci., v. 25, n. 3, p. 586-596, 2018.

AMADOR, P. et al. Prevalence of Antibiotic Resistance Genes in Multidrug-Resistant Enterobacteriaceae on Portuguese Livestock Manure. Antibiotics, v. 8, n. 1, p. 23, 2019.

AMIN, N. E. et al. Carbapenem resistance mechanisms in Pseudomonas aeruginosa: alterations of porin OprD and efflux proteins do not fully explain resistance patterns observed in clinical isolates. APMIS, v. 113, n. 3, p. 187-196, 2005.

ANVISA, Agência Nacional de Vigilância Sanitária. Antimicrobianos - Bases Teóricas e Uso Clínico. ANVISA, 2019. Disponível em:

https://www.anvisa.gov.br/servicosaude/controle/rede_rm/cursos/rm_controle/opas_ web/modulo1/quinilonas.htm

ARGUDíN, M. A. et al. Bacteria from animals as a pool of antimicrobial resistance genes. Antibiotics, v. 6, n. 2, p. 12, 2017.

ARUMUGAM, M. et al. Enterotypes of the human gut microbiome. Nature, v. 473, n. 7346, p. 174-180, 2011. 
AYUKEKBONG, J. A.; NTEMGWA, M.; ATABE, A. N. The threat of antimicrobial resistance in developing countries: causes and control strategies. Antimicrob. Resist. Infect. Control, v. 6, n. 1, p. 47, 2017.

BAG, S. et al. Molecular insights into antimicrobial resistance traits of commensal human gut microbiota. Microb. Ecol. v. 77, n. 2, p. 546-557, 2019.

BAILEY, J.K. et al. Commensal Escherichia coli of healthy humans: a reservoir for antibiotic-resistance determinants. J. Med. Microbiol. v. 59, n. 11, p. 1331-1339, 2010 doi:10.1099/jmm.0. 022475-0

BAL, A. M. et al. Future trends in the treatment of methicillin-resistant Staphylococcus aureus (MRSA) infection: an in-depth review of newer antibiotics active against an enduring pathogen. J. Glob. Antimicrob. Resist. v. 10, p. 295303, 2017.

BAQUERO, F.; TEDIM, A. S. P.; COQUE, T. M. Antibiotic resistance shaping multilevel population biology of bacteria. Front. Microbiol. v. 4, p. 15, 2013.

BAQUERO, F. Metagenomic epidemiology: a public health need for the control of antimicrobial resistance. Clin. Microbiol. Infect. v. 18, p. 67-73, 2012.

BARAN, W. et al. Effects of the presence of sulfonamides in the environment and their influence on human health. J. Hazard. Mater. v. 196, p. 1-15, 2011.

BARTOLONI, A. et al. Antibiotic resistance in a very remote Amazonas community.Int. J. Antimicrob. Agents, v. 33, n. 2, p. 125-129, 2009. doi:10.1016/ j.ijantimicag.2008.07.029

BELL, B. G. et al. A systematic review and meta-analysis of the effects of antibiotic consumption on antibiotic resistance.BMC Infect. Dis. v. 14, n. 1, p. 13, 2014.

BENGTSSON-PALME, J. et al.The human gut microbiome as a transporter of antibiotic resistance genes between continents. Antimicrob. Agents Chemother., v. 59, n. 10, p. 6551-6560, 2015.

BERGLUND, B. Environmental dissemination of antibiotic resistance genes and correlation to anthropogenic contamination with antibiotics, Infect. Ecol. Epidemiology, v. 5, n. 1, 2015.

BHATIA, R.; KATOCH, V. M.; INOUE, H. Creating political commitment for antimicrobial resistance in developing countries. Indian J. Med. Res. v. 149, n. 2, p. 83, 2019.

BRASIL.Resolução da Diretoria Colegiada n 44, de 26 de outubro de 2010. Dispõe sobre o controle dos medicamentos à base de substâncias antimicrobianas. Diário Oficial da União, Brasília, 28 de outubro de 2010.

BRASIL. Resolução da Diretoria Colegiada $n^{\circ} 20$, de 5 de maio de 2011. Dispõe sobre o controle dos medicamentos à base de substâncias antimicrobianas. Diário Oficial da União, Brasília, 9 de maio de 2011 
BRASIL. Agência Nacional de Vigilância Sanitária - ANVISA. Plano Nacional para Prevenção e Controle da Resistência Microbiana nos Serviços de Saúde. Brasília: ANVISA, $2017 . \quad$ Disponível em: http://portal.anvisa.gov.br/documents/33852/271855/Plano+Nacional+para+a+Preve n\%C3\%A7\%C3\%A3o+e+o+Controle+da+Resist\%C3\%AAncia+Microbiana+nos+Ser vi\%C3\%A7os+de+Sa\%C3\%BAde/9d9f63f3-592b-4fe1-8ff2-e035fcc0f31d

BRASIL. Ministério da Saúde. Secretaria de Vigilância em Saúde. Departamento de Vigilância das Doenças Transmissíveis. Plano de ação nacional de prevenção e controle da resistência aos antimicrobianos no âmbito da saúde única 2018-2022 (PAN-BR) / Ministério da Saúde, Secretaria de Vigilância em Saúde, Departamento de Vigilância das Doenças Transmissíveis. - Brasília: Ministério da Saúde, 2018. Disponível em: https://portalarquivos2.saude.gov.br/images/pdf/2018/dezembro/20/af-pan-br17dez18-20x28-csa.pdf

BRASIL. Resolução da Diretoria Colegiada n 331, de 23 de dezembro de 2019. Dispõe sobre os padrões microbiológicos de alimentos e sua aplicação. Diário Oficial da União, Brasília, 26 de dezembro de 2019.

BRASIL. Ministério da Saúde. Secretaria de Ciência, Tecnologia e Insumos Estratégicos. Departamento de Assistência Farmacêutica e Insumos Estratégicos. Relação Nacional de Medicamentos Essenciais : RENAME 2020 / Ministério da Saúde, Secretaria de Ciência, Tecnologia e Insumos Estratégicos, Departamento de Assistência Farmacêutica e Insumos Estratégicos. - Brasília : Ministério da Saúde, 2020.

BRASIL. Agência Nacional de Vigilância Sanitária, ANVISA. Boletim Segurança do Paciente e Qualidade em Serviços de Saúde $n^{\circ}$ 22: Avaliação dos indicadores nacionais das Infecções Relacionadas à Assistência à Saúde (IRAS) e Resistência microbiana (RM), ano 2019. ANVISA, 2021. Disponível em: https://app.powerbi.com/view?r=eyJrljoiZjQ5ZDhjZmEtNDdhOC00MDk3LWFiNDEtN zg0MmE4MmE2MjlhliwidCI6ImI2N2FmMjNmLWMzZjMtNGQzNS04MGM3LWI3MDg 1ZjVIZGQ4MSJ9\&pageName=ReportSectionac5c0437dbe709793b4b

CABELLO, F. C. Heavy use of prophylactic antibiotics in aquaculture: a growing problem for human and animal health and for the environment. Environ. Microbiol. v. 8, n. 7, p. 1137-1144, 2006.

CALERO-CÁCERES, W.; YE, M.; BALCÁZAR, J. L. Bacteriophages as environmental reservoirs of antibiotic resistance. Trends Microbiol. 2019.

CAMBRAY, G.; GUEROUT, A-M; MAZEL, Didier. Integrons. Annu. Rev. Genet. v. 44, p. 141-166, 2010.

CANIÇA, M. et al. Antibiotic resistance in foodborne bacteria. Trends Food Sci. Technol. v. 84, p. 41-44, 2019.

CANTÓN, R.; GONZÁLEZ-ALBA, J. M.; GALÁN, J. C. CTX-M enzymes: origin and diffusion. Front. Microbiol. v. 3, p. 110, 2012. 
$\mathrm{CAO}$, J. et al. Metagenomic analysis reveals the microbiome and resistome in migratory birds. Microbiome, v. 8, n. 1, p. 1-18, 2020.

CARDOSO, M. A.; STOCCO, P. R. Desenvolvimento de um questionário quantitativo de freqüência alimentar em imigrantes japoneses e seus descendentes residentes em São Paulo, Brasil. Cadernos de Saúde Pública, v. 16, p. 107-114, 2000.

CARUSO, G. et al. Extra-intestinal fluoroquinolone-resistant Escherichia coli strains isolated from meat. BioMed Res. Int. v. 2018, 2018.

CASALS-PASCUAL, C.; VERGARA, A.; VILA, J. Intestinal microbiota and antibiotic resistance: Perspectives and solutions. Hum. Microbiome J. v. 9, p. 11-15, 2018.

CASEWELL, M. et al.The European ban on growth-promoting antibiotics and emerging consequences for human and animal health. J. Antimicrob. Chemother. v. 52 , n. 2, p. 159-161, 2003.

CATTOIR, V. Mechanisms of antibiotic resistance. In: Streptococcus pyogenes:

Basic Biology to Clinical Manifestations [Internet]. University of Oklahoma Health Sciences Center, 2016.

CHAIEB, K. et al. Antibiotic resistance genes detected by multiplex PCR assays in Staphylococcus epidermidis strains isolated from dialysis fluid and needles in a dialysis service. Jpn J. Infect. Dis. v. 60, n. 4, p. 183, 2007.

CHEN, Q- L. et al. Antibiotic resistomes in plant microbiomes. Trends Plant Sci. v. 24, n. 6, p. 530-541, 2019.

CHENIA, H. Y. Prevalence and characterization of plasmid-mediated quinolone resistance genes in Aeromonas spp. isolated from South African freshwater fish. Int. J. Food Microbiol. v. 231, p. 26-32, 2016.

CHERRY, E. Veganism as a cultural movement: A relational approach. Soc. Mov. Stud. v. 5, n. 2, p. 155-170, 2006.

CLAESSON, M. J. et al. Composition, variability, and temporal stability of the intestinal microbiota of the elderly.Proc. Natl. Acad. Sci. U.S.A. v. 108, n. Supplement 1, p. 4586-4591, 2011.

CLEMENTE, J. C. et al. The microbiome of uncontacted Amerindians. Sci. Adv., v. 1, n. 3, 2015.

COMUNIAN, R. et al. Susceptibility to tetracycline and erythromycin of Lactobacillus paracasei strains isolated from traditional Italian fermented foods. Int. J. Food Microbiol. v. 138, n. 1-2, p. 151-156, 2009.

COLE, D. et al. Free-living Canada geese and antimicrobial resistance.Emerg. Infect. Dis. v. 11, n. 6, p. 935-938, 2005.

COLOMER-LLUCH, $M$. et al. Antibiotic resistance genes in bacterial and bacteriophage fractions of Tunisian and Spanish wastewaters as markers to compare 
the antibiotic resistance patterns in each population. Environ. Int. v. 73, p. 167-175, 2014.

COSTEA, P. I. et al. Enterotypes in the landscape of gut microbial community composition. Nat. Microbiol. v. 3, n. 1, p. 8-16, 2018.

COTON, M. et al. Biogenic amine and antibiotic resistance profiles determined for lactic acid bacteria and a propionibacterium prior to use as antifungal bioprotective cultures. Int. Dairy J. v. 85, p. 21-26, 2018.

CROUCHER, N. J. et al. Horizontal DNA Transfer Mechanisms of Bacteria as Weapons of Intragenomic Conflict.PLoS Biol. v. 14, n. 3, 2016.

D' COSTA, V. M.; GRIFFITHS, E.; WRIGHT, G. D. Expanding the soil antibiotic resistome: exploring environmental diversity. Curr. Opin. Microbiol. v. 10, n. 5, p. 481-489, 2007.

D' CostA, V. M. et al. Antibiotic resistance is ancient. Nature, v. 477, n. 7365, p. 457, 2011.

DANTAS, G.; SOMMER, M. O. A. Context matters-the complex interplay between resistome genotypes and resistance phenotypes. Curr. Opin. Microbiol. v. 15, n. 5, p. 577-582, 2012.

DAY, M. J. et al. Extended-spectrum $\beta$-lactamase-producing Escherichia coli in human-derived and foodchain-derived samples from England, Wales, and Scotland: an epidemiological surveillance and typing study. Lancet Infect. Dis. v. 19, n. 12, p. 1325-1335, 2019.

DE ATTAYDE, J. L.; ISKIN, M.; CARNEIRO, L. O papel da onivoria na dinâmica das cadeias alimentares. Oecol. Bras. v. 10, n. 1, p. 4, 2006.

DE LASTOURS, V. et al. Ceftriaxone promotes the emergence of AmpCoverproducing Enterobacteriaceae in gut microbiota from hospitalized patients. Eur. J. Clin. Microbiol. Infect. Dis. v. 37, n. 3, p. 417-421, 2018.

DE PAULA, A. C. L. et al. Antibiotic resistance genetic markers and integrons in white soft cheese: aspects of clinical resistome and potentiality of horizontal gene transfer. Genes, v. 9, n. 2, p. 106, 2018.

DE SOUZA, M. M. S. et al. Antimicrobial Resistance in Animal Production: an Overview. Braz. J. Vet. Med., v. 38, n. Supl. 3, p. 68-74, 2016.

DENG, Y. et al. Resistance integrons: class 1, 2 and 3 integrons. Ann. Clin. Microbiol. Antimicrob., v. 14, n. 1, p. 45, 2015.

DESTOUMIEUX-GARZÓN, D. et al. The one health concept: 10 years old and a long road ahead. Front. Vet. Sci., v. 5, p. 14, 2018.

DEVIRGILIIS, C.; BARILE, S.; PEROZZI, G. Antibiotic resistance determinants in the interplay between food and gut microbiota. Genes Nutr., v. 6, n. 3, p. 275, 2011. 
DEVIRGILIIS, C. et al. Identification of tetracycline- and erythromycin-resistant Grampositive cocci within the fermenting microflora of an Italian dairy food product. J. Appl. Microbiol. v. 109, n. 1, p. 313-323, 2010.

[ONÍVORO]. In: DICIO, Dicionário Online de Português. Porto: 7Graus, 2018. Disponível em: https://www.dicio.com.br/onivorol. Acesso em: 01/06/2019.

DOLEJSKA, M.; CIZEK, A.; LITERAK, I. High prevalence of antimicrobial-resistant genes and integrons in Escherichia coli isolates from black-headed gulls in the Czech Republic. J. Appl. Microbiol. v.103, n. 1, p. 11-19, 2007.

DOMINGO, M. C. et al. High prevalence of glycopeptide resistance genes vanB, vanD, and vanG not associated with enterococci in human fecal flora. Antimicrob. Agents Chemother., v. 49, n. 11, p. 4784-4786, 2005.

DOWSON, C.G.; COFFEY, T.J.; SPRATT, B.G. Origin and molecular epidemiology of penicillin-binding-protein-mediated resistance to $\beta$-lactam antibiotics.Trends Microbiol. v. 2, n. 10, p. 361-366, 1994.

DUAN, Y. et al. Gut resistomes, microbiota and antibiotic residues in Chinese patients undergoing antibiotic administration and healthy individuals. Sci. Total Environ. v. 705, p. 135674, 2020.

DWYER, J. T. Nutritional consequences of vegetarianism. Annu. Rev. Nutr. v. 11, n. 1, p. 61-91, 1991.

ECDC, European Centre for Disease Prevention and Control. Antimicrobial resistance in the EU/EEA (EARS-Net) - Annual Epidemiological Report 2019. Stockholm: $\quad$ ECDC; 2020.2 Disponível em: https://www.ecdc.europa.eu/en/publications-data/surveillance-antimicrobialresistance-europe-2019

ESCANDÓN-VARGAS, K. et al. The epidemiology of carbapenemases in Latin America and the Caribbean. Expert Rev. Anti. Infect. Ther. v. 15, n. 3, p. 277-297, 2017.

FARON, M. L.; LEDEBOER, N. A.; BUCHAN, B. W. Resistance mechanisms, epidemiology, and approaches to screening for vancomycin-resistant Enterococcus in the health care setting.J. Clin. Microbiol., v. 54, n. 10, p. 2436-2447, 2016.

FEßLER, A. T. et al. Mobile macrolide resistance genes in staphylococci. Plasmid. v. 99, p. 2-10, 2018.

FENG, J. et al. Antibiotic resistome in a large-scale healthy human gut microbiota deciphered by metagenomic and network analyses. Environ. Microbiol. v. 20, n. 1 , p. 355-368, 2018.

FERREIRA, A. M. et al. Correlation of phenotypic tests with the presence of the blaZ gene for detection of beta-lactamase. Braz. J. Microbiol. v. 48, n. 1, p. 159-166, 2017. 
FERROCINO, I. et al. Fecal microbiota in healthy subjects following omnivore, vegetarian and vegan diets: culturable populations and rRNA DGGE profiling. PLoS One, v. 10, n. 6, 2015.

FILHO, J. D.; BARROSO, C. M. Dieta e dislipidemia: visão antropológica e recomendações atuais. HU Rev. v. 33, n. 3, p. 83-100, 2007.

FITZPATRICK, D.; WALSH, F. Antibiotic resistance genes across a wide variety of metagenomes. FEMS Microbiol. Ecol. v. 92, n. 2, p. fiv168, 2016.

FORSLUND, K. et al. Country-specific antibiotic use practices impact the human gut resistome. Genome Res. v. 23, n. 7, p. 1163-1169, 2013.

FURNESS, L. E. et al. Wild small mammals as sentinels for the environmental transmission of antimicrobial resistance. Environ. Res. v. 154, p. 28-34, 2017.

GALES, A.C.; MENEZES, L.C.; SILBERT, S.; SADER, H.S. Dissemination in distinct Brazilian regions of an epidemic carbapenem-resistant Pseudomonas aeruginosa producing SPM metallo- $\beta$-lactamase.J. Antimicrob. Chemother., v. 52, n. 4, p. 699702, 2003.

GARNACHO-MONTERO, J.; TIMSIT, J. F. Managing Acinetobacter baumannii infections.Curr. Opin. Infect. Dis. v. 32, n. 1, p. 69-76, 2019.

GHAFOURIAN, S. et al. Extended spectrum beta-lactamases: definition, classification and epidemiology. Curr Issues Mol. Biol. v. 17, n. 1, p. 11-22, 2015.

GHALY, T. M. et al. The Peril and Promise of Integrons: Beyond Antibiotic Resistance. Trends Microbiol., 2020.

GILLINGS, M. R. Evolutionary consequences of antibiotic use for the resistome, mobilome and microbial pangenome. Front. Microbiol. v. 4, p. 4, 2013.

GILLINGS, M. R.; PAULSEN, I. T.; TETU, S. G. Ecology and evolution of the human microbiota: fire, farming and antibiotics. Genes, v. 6, n. 3, p. 841-857, 2015.

GILLIVER, M. A. et al. Antibiotic resistance found in wild rodents. Nature, v. 401, n. 6750, p. 233-234, 1999.

GRAHAM, M. et al. High rates of fecal carriage of nonenterococcal vanB in both children and adults. Antimicrob. Agents Chemother. v. 52, n. 3, p. 1195-1197, 2008.

GRAPE, M.; SUNDSTRÖM, L.; KRONVALL, G. Sulphonamide resistance gene sul3 found in Escherichia coli isolates from human sources.J. Antimicrob. Chemother., v. 52, n. 6, p. 1022-1024, 2003.

GUEIMONDE, M. et al. Antibiotic resistance in probiotic bacteria. Front. Microbiol. v. 4 , p. $202,2013$. 
GUMPERT, $H$. et al. Transfer and persistence of a multi-drug resistance plasmid in situ of the infant gut microbiota in the absence of antibiotic treatment. Front. Microbiol. v. 8, p. 1852, 2017.

HAMMERUM, A. M.; LESTER, C. H.; HEUER, O. E. Antimicrobial-resistant enterococci in animals and meat: a human health hazard? Foodborne Pathog. Dis.v. 7 , n. 10, p. 1137-1146. 2010. doi: 10.1089/fpd.2010.0552

HEUER, O. E. et al. Human health consequences of use of antimicrobial agents in aquaculture. Clin. Infect. Dis. v. 49, n. 8, p. 1248-1253, 2009.doi: 10.1086/605667

$\mathrm{HO}$, J. et al. Systematic review of human gut resistome studies revealed variable definitions and approaches. Gut Microbes, p. 1-12, 2020.

HOLMES, A. H. et al. Understanding the mechanisms and drivers of antimicrobial resistance. The Lancet, v. 387, n. 10014, p. 176-187, 2016.

HORCAJADA, J. P. et al. Epidemiology and treatment of multidrug-resistant and extensively drug-resistant Pseudomonas aeruginosa infections. Clin. Microbiol. Rev. v. 32, n. 4, p. e00031-19, 2019.

$\mathrm{HU}, \mathrm{Y}$. et al. Metagenome-wide analysis of antibiotic resistance genes in a large cohort of human gut microbiota. Nat. Commun. v. 4, n. 1, p. 1-7, 2013.

ISEPPI, R. et al. Antibiotic Resistance and Virulence Traits in Vancomycin-Resistant Enterococci (VRE) and Extended-Spectrum $\beta$-Lactamase/AmpC-producing (ESBL/AmpC) Enterobacteriaceae from Humans and Pets. Antibiotics, v. 9, n. 4, p. 152, 2020.

JANG, H. M. et al. Prevalence of antibiotic resistance genes from effluent of coastal aquaculture, South Korea. Environ. Pollut. v. 233, p. 1049-1057, 2018.

JANSSEN, M. et al. Motives of consumers following a vegan diet and their attitudes towards animal agriculture. Appetite, v. 105, p. 643-651, 2016.

JONES, C.H. et al. Characterization and sequence analysis of extended-spectrum- $\beta$ lactamase-encoding genes from Escherichia coli, Klebsiella pneumoniae, and Proteus mirabilis isolates collected during tigecycline phase 3 clinical trials. Antimicrob.Agents Chemother. v. 53, n. 2, p. 465-475, 2009.

KARKMAN, A.; PÄRNÄNEN, K.; LARSSON, D.G. J. Fecal pollution can explain antibiotic resistance gene abundances in anthropogenically impacted environments. Nat. Commun. v. 10, n. 1, p. 1-8, 2019.

KIM, H.B. et al. Prevalence of plasmid-mediated quinolone resistance determinants over a 9-year period.Antimicrob. Agents Chemother., v. 53, n. 2, p. 639-645, 2009.

KIM, D. W.; CHA, C. J. Antibiotic resistome from the One-Health perspective: Understanding and controlling antimicrobial resistance transmission. Exp. Mol. Med. p. 1-9, 2021. 
$\mathrm{KOCH}$, B. J.; HUNGATE, B. A.; PRICE, L. B. Food-animal production and the spread of antibiotic resistance: the role of ecology. Front. Ecol. Environ. v. 15, n. 6, p. 309318, 2017.

KOCZURA, R. et al. Abundance of class 1 integron-integrase and sulfonamide resistance genes in river water and sediment is affected by anthropogenic pressure and environmental factors. Microb. Ecol. v. 72, n. 4, p. 909-916, 2016.

KOIKE, S. et al. Agricultural use of antibiotics and antibiotic resistance. Antibiotic resistance genes in natural environments and long-term effects, p. 217-50, 2017.

KYSELKOVÁ, M. et al. Tetracycline resistance genes persist in soil amended with cattle feces independently from chlortetracycline selection pressure. Soil Biol.

Biochem. v. 81, p. 259-265, 2015.

LAKHUNDI, S.; ZHANG, K. Methicillin-resistant Staphylococcus aureus: molecular characterization, evolution, and epidemiology. Clin. Microbiol. Rev. v. 31, n. 4, p. e00020-18, 2018.

LANGE, K. et al. Effects of antibiotics on gut microbiota. Dig. Dis., v. 34, n. 3, p. 260268, 2016.

LARRAÑAGA, O. et al. Phage particles harboring antibiotic resistance genes in fresh-cut vegetables and agricultural soil.Environ. Int. v. 115, p. 133-141, 2018.

LEE, K. et al. Mobile resistome of human gut and pathogen drives anthropogenic bloom of antibiotic resistance. Microbiome, v. 8, n. 1, p. 1-14, 2020.

LEVY, S. B.; MARSHALL, B. Antibacterial resistance worldwide: causes, challenges and responses. Nat. Med. v. 10, n. 12, p. S122, 2004.

LEVY, S. B.; FITZGERALD, G. B.; MACONE, A. B..Changes in intestinal flora of farm personnel after introduction of a tetracycline-supplemented feed on a farm. N. Engl. J. Med. v. 295, n.11, p. 583-588, 1976a doi: 10.1056/NEJM197609092951103

LEVY, S. B.; FITZGERALD, G. B.; MACONE, A. B. Spread of antibiotic-resistant plasmids from chicken to chicken and from chicken to man. Nature,v. 260, n. 5546, p. $40-42,1976 b$

$\mathrm{LI}, \mathrm{B}$. et al. Metagenomic and network analysis reveal wide distribution and cooccurrence of environmental antibiotic resistance genes. ISME J. v. 9, n. 11, p. 24902502, 2015.

LI, X- Z.; PLÉSIAT, P. Antimicrobial drug efflux pumps in Pseudomonas aeruginosa. In: Efflux-Mediated Antimicrobial Resistance in Bacteria. Adis, Cham, p. 359-400, 2016.

LIN, H. et al. Fate of tetracycline and sulfonamide resistance genes in a grassland soil amended with different organic fertilizers. Ecotoxicol. Environ. Saf. v. 170, p. 39-46, 2019. 
LOGAN, L. K.; WEINSTEIN, R. A. The epidemiology of carbapenem-resistant Enterobacteriaceae: the impact and evolution of a global menace. J. Infect. Dis. v. 215, n. suppl_1, p. S28-S36, 2017.

LOOFT, T. et al. In-feed antibiotic effects on the swine intestinal microbiome. Proc. Natl. Acad. Sci. U.S.A. v. 109, n. 5, p. 1691-1696, 2012. doi: 10.1073/ pnas. 1120238109

LOPATKIN, A. J. et al. Antibiotics as a selective driver for conjugation dynamics. Nat. Microbiol. v. 1, n. 6, p. 1-8, 2016.

LOSASSO, C. et al. Assessing the influence of vegan, vegetarian and omnivore oriented Westernized dietary styles on human gut microbiota: a cross sectional study. Front. Microbiol. v. 9, p. 317, 2018a.

LOSASSO, C et al. Assessing antibiotic resistance gene load in vegan, vegetarian and omnivore human gut microbiota. Int. J. Antimicrob. Agents, 2018b.

MA, L. et al.The prevalence of integrons as the carrier of antibiotic resistance genes in natural and man-made environments. Environ. Sci. Technol. v. 51, n. 10, p. 5721-5728, 2017.

MACHADO, E. et al. Integron content of extended-spectrum- $\beta$-lactamase-producing Escherichia coli strains over 12 years in a single hospital in Madrid, Spain. Antimicrob. Agents Chemother. v. 49, n. 5, p. 1823-1829, 2005.

MACHADO, E. et al. Commensal Enterobacteriaceae as reservoirs of extendedspectrum beta-lactamases, integrons, and sul genes in Portugal. Front. Microbiol. v. 4, p. 80, 2013.

MAHAMAT, O. O. et al. Fecal carriage of extended-spectrum $\beta$-lactamase-producing Enterobacteriaceae in hospital and community settings in Chad. Antimicrob. Resist. Infect. Control, v. 8, n. 1, p. 1-7, 2019.

MAKAYA, P. N. et al. Emergence of Antibiotic Resistance and Correlation with the Efflux Pump in Pseudomonas aeruginosa Isolated from Abidjan Hospital. Int. J. Sci.

Res. v. 6, n. 3, p. 481-90, 2017.

MALIN, J. et al. Longitudinal fluctuations of common antimicrobial resistance genes in the gut microbiomes of healthy Dutch individuals. Metagenomic insights into the reservoirs and dissemination of antibiotic resistance, p. 83, 2016.

MAROSEVIC, D.; KAEVSKA, M.; JAGLIC, Z. Resistance to the tetracyclines and macrolide-lincosamide-streptogramin group of antibiotics and its genetic linkage-a review. Ann. Agric. Environ. Med. v. 24, n. 2, p. 338-344, 2017.

MARTINEAU, F. et al. Correlation between the resistance genotype determined by multiplex PCR assays and the antibiotic susceptibility patterns of Staphylococcus aureus and Staphylococcus epidermidis. Antimicrob. Agents Chemother. v. 44, n. 2, p. 231-238, 2000. 
MATIJAŠIĆ, B. B. et al. Association of dietary type with fecal microbiota in vegetarians and omnivores in Slovenia. Euro. J. Nutr. v. 53, n. 4, p. 1051-1064, 2014.

MEINI, S. et al. AmpC $\beta$-lactamase-producing Enterobacterales: what a clinician should know. Infection, p. 1-13, 2019.

MEJÍA, C.; ZURITA, J.; GUZMÁN-BLANCO, M. Epidemiology and surveillance of methicillin-resistant Staphylococcus aureus in Latin America. Braz. J. Infect. Dis. v. 14, p. 79-86, 2010.

MELNYK, A. H.; WONG, A.; KASSEN, R. The fitness costs of antibiotic resistance mutations. Evol. Appl. v. 8, n. 3, p. 273-283, 2015.

MENDES, R. E.; DESHPANDE, L. M.; JONES, R. N. Linezolid update: stable in vitro activity following more than a decade of clinical use and summary of associated resistance mechanisms. Drug Resist. Updat. v. 17, n. 1-2, p. 1-12, 2014.

MEUMANN, E. M. et al. Genomic epidemiology of severe community-onset Acinetobacter baumannii infection.Microb. Genom. v. 5, n. 3, 2019.

MILANI, C. et al. The first microbial colonizers of the human gut: composition, activities, and health implications of the infant gut microbiota. Microbiol. Mol. Biol. Rev. v. 81, n. 4, p. e00036-17, 2017.

MILANOVIĆ, V. et al. Occurrence of antibiotic resistance genes in the fecal DNA of healthy omnivores, ovolactovegetarians and vegans. Mol. Nutr. Food Res. v. 61, n. 9, p. 1601098, 2017.

MOFFA, M.; BROOK, I. 26-Tetracyclines, glycylcyclines, and chloramphenicol. Mandell, Douglas, and Bennett's Principles and Practice of Infectious Diseases. 8th ed. Philadelphia: Saunders, p. 322-38, 2015.

MOLLOY, E. M.; HERTWECK, C. Antimicrobial discovery inspired by ecological interactions.Curr. Opin. Microbiol. v. 39, p. 121-127, 2017.

MORAČANIN, S. V. et al. Antimicrobial resistance of lactic acid bacteria in fermented food. J. Hyg. Eng. Des. v. 18, p. 25-35, 2017.

MOSCHEN, A. R.; WIESER, V.; TILG, H. Dietary factors: major regulators of the gut's microbiota. Gut Liver, v. 6, n. 4, p. 411, 2012.

$\mathrm{MU}, \mathrm{Q}$. et al. Occurrence of sulfonamide-, tetracycline-, plasmid-mediated quinolone and macrolide-resistance genes in livestock feedlots in Northern China. Environ.

Sci. Pollut. Res. v. 22, n. 9, p. 6932-6940, 2015.

NAQUIN, T. et al. Presence of sulfonamide and carbapenem resistance genes in a sewage treatment plant in Southeast Louisiana, USA. Int. Biodeter. Biodegr. v. 124, p. 10-16, 2017.

NARIMANI, T. et al. Heterogeneity in resistant fecal Bacteroides fragilis group collected from healthy people. Microb. Pathog. v. 95, p. 1-6, 2016. 
NG, L.K. et al. Multiplex PCR for the detection of tetracycline resistant genes. Mol. Cell. Probes, v. 15, n. 4, p. 209-215, 2001.

NIESTEPPSKI, S. et al. The emergence of antimicrobial resistance in environmental strains of the Bacteroides fragilis group. Environ. Int. v. 124, p. 408-419, 2019.

NOBLES, M. History counts: a comparative analysis of racial/color categorization in US and Brazilian censuses. Am. J. Public Health, v. 90, n. 11, p. 1738, 2000.

NORDMANN, P.; DORTET, L.; POIREL, L. Carbapenem resistance in Enterobacteriaceae: here is the storm! Trends Mol. Med. v. 18, n. 5, p. 263-272, 2012.

O'DRISCOLL, T.; CRANK, C. W. Vancomycin-resistant enterococcal infections: epidemiology, clinical manifestations, and optimal management. Infect. Drug Resist. v. 8, p. $217,2015$.

O'NEILL, J. et al. Review on antimicrobial resistance, tackling drug-resistant infections globally: final report and recommendations. London: Wellcome Trust and UK Government, 2016.

OKEKE, I. N. et al. Antimicrobial resistance in developing countries. Part II: strategies for containment. Lancet Infect. Dis. v. 5, n. 9, p. 568-580, 2005.

OLIVER, A. et al. The increasing threat of Pseudomonas aeruginosa high-risk clones.Drug Resist. Updat. v. 21, p. 41-59, 2015.

PAL, C. et al.The structure and diversity of human, animal and environmental resistomes. Microbiome, v. 4, n. 1, p. 1-15, 2016.

PHAM, T. D. M.; ZIORA, Z. M.; BLASKOVICH, M. A. T. Quinolone antibiotics. Med. Chem. Comm. v. 10, n. 10, p. 1719-1739, 2019.

POONSUK, K. et al. Detection of the mex efflux pumps in Pseudomonas aeruginosa by using a combined resistance-phenotypic markers and multiplex RT-PCR. Open J. Med. Microbiol. v. 4, n. 03, p. 153, 2014.

POPA, O.; DAGAN, T. Trends and barriers to lateral gene transfer in prokaryotes.Curr. Opin. Microbiol. v. 14, n. 5, p. 615-623, 2011.

POURAKBARI, B. et al. Evaluation of efflux pumps gene expression in resistant Pseudomonas aeruginosa isolates in an Iranian referral hospital. Iran. J. Microbiol. v. 8, n. 4, p. 249, 2016.

RANJBAR, R. et al. Antibiotic resistance and prevalence of class 1 and 2 integrons in Escherichia coli isolated from hospital wastewater. Univ. Med. v. 37, n. 3, p. 209215, 2018.

RAPHAEL, E.; WONG, L. K.; RILEY, L. W. Extended-spectrum Beta- lactamase gene sequences in gram- negative saprophytes on retail organic and non organic spinach. Appl. Environ. Microbiol. v. 77, n. 5, p. 1601-1607, 2011. 
RESENDE, J. A. et al. Antimicrobial-Resistance Genetic Markers in Potentially Pathogenic Gram Positive Cocci Isolated from Brazilian Soft Cheese. J. Food Sci. v. 83, n. 2, p. 377-385, 2018.

RIZZATTI, G. et al. Proteobacteria: a common factor in human diseases. BioMed Res. Int. v. 2017, 2017.

ROBERTS, M. C. Environmental macrolide-lincosamide-streptogramin and tetracycline resistant bacteria. Front. Microbiol. v. 2, p. 40, 2011.

ROBINSON, T. P. et al. Antibiotic resistance is the quintessential One Health issue. Trans. R. Soc. Trop. Med. Hyg. v. 110, n. 7, p. 377-380, 2016.

ROCCHETTI, T. T. et al. Detection of the mecA gene and identification of Staphylococcus directly from blood culture bottles by multiplex polymerase chain reaction. Braz. J. Infect. Dis. v. 22, n. 2, p. 99-105, 2018.

ROLLAND, R. M. et al. Antibiotic-resistant bacteria in wild primates: increased prevalence in baboons feeding on human refuse. Appl. Environ. Microbiol. v. 49, n. 4, p. 791-794, 1985.

ROSSI, F. et al. Transferable vancomycin resistance in a community-associated MRSA lineage. N. Engl. J. Med. v. 370, n. 16, p. 1524-1531, 2014.

RUBY, M. B. Vegetarianism.A blossoming field of study. Appetite, v. 58, n. 1, p. 141150, 2012.

RUBIN, J. E.; EKANAYAKE, S.; FERNANDO, C. Carbapenemase-producing organism in food, Emerg. Infect. Dis. v. 20, n. 7, p. 1264-1265, 2014.

RUIZ-GARBAJOSA, P.; CANTÓN, R. Epidemiology of antibiotic resistance in Pseudomonas aeruginosa.Implications for empiric and definitive therapy.Rev. Esp. Quimioter. v. 30, 2017.

SAKKAS, $\mathrm{H}$. et al. Nutritional Status and the Influence of the Vegan Diet on the Gut Microbiota and Human Health. Medicina, v. 56, n. 2, p. 88, 2020.

SALES, R. L.; COSTA, N. M. B.; SILVA, M. M. S. Avaliando o consumo alimentar por fotos. Universidade Federal de Viçosa, p. 1-40, 2004.

SÁNCHEZ-OSUNA, M. al. Origin of the mobile di-hydro-pteroate synthase gene determining sulfonamide resistance in clinical isolates. Front. Microbiol. v. 9, p. 3332, 2019.

SANTIAGO-RODRIGUEZ, T. M. et al. Gut microbiome of an 11 th century AD PreColumbian Andean mummy. PloS One, v. 10, n. 9, p. e0138135, 2015.

SANTIAGO-RODRIGUEZ, T. M. et al. Tetracycline-like resistome of ancient human guts. Hum. Microbiome J. v. 10, p. 21-26, 2018. 
SARKAR, A. et al. Detection of integron- associated gene cassettes and other antimicrobial resistance genes in enterotoxigenic Bacteroides fragilis. Anaerobe, v. 33, p. 18-24, 2015.

SARMIENTO, M. R. A. et al. Obesity, xenobiotic intake and antimicrobial-resistance genes in the human gastrointestinal tract: A comparative study of eutrophic, overweight and obese individuals. Genes, v. 10, n. 5, p. 349, 2019.

SCHILL, F. et al. Prevalence and characterization of extended-spectrum $\beta$-lactamase (ESBL) and AmpC $\beta$-lactamase producing Enterobacteriaceae in fresh pork meat at processing level in Germany. Int. J. Food Microbiol. v. 257, p. 58-66, 2017.

SENGHOR, B. et al. Gut microbiota diversity according to dietary habits and geographical provenance. Hum. Microbiome J. v. 7, p. 1-9, 2018.

SERIO, A. W. et al. Aminoglycosides: Mechanisms of action and resistance. In: Antimicrobial Drug Resistance. Springer, Cham, p. 213-229, 2017.

SHAIKH, S. et al. Antibiotic resistance and extended spectrum beta-lactamases: Types, epidemiology and treatment. Saudi J. Biol. Sci. v. 22, n. 1, p. 90-101, 2015.

SILVA, K. C. da; LINCOPAN, N. Epidemiologia das betalactamases de espectro estendido no Brasil: impacto clínico e implicações para o agronegócio. J. Bras. Patol. Med. Lab. v. 48, n. 2, p. 91-99, 2012.

SINGH, S.; VERMA, N.; TANEJA, N. The human gut resistome: Current concepts \& future prospects. Ind. J. Med. Res. v. 150, n. 4, p. 345, 2019.

SILBY, M.W. et al.Pseudomonas genomes: diverse and adaptable. FEMS Microbiol. Rev.v. 35, n. 4, p. 652-680, 2011.

SOMMER, M.O.; CHURCH, G.M.; DANTAS, G. The human microbiome harbors a diverse reservoir of antibiotic resistance genes. Virulence, v. 1, n. 4, p. 299-303, 2010.

SOMMER, F. et al. The resilience of the intestinal microbiota influences health and disease. Nat. Rev. Microbiol. v. 15, n. 10, p. 630, 2017.

SORENSEN, S.J. et al. Studying plasmid horizontal transfer in situ: A critical review. Nat. Rev. Microbiol., v. 3, n. 9, p. 700-710, 2005.

SOSA, A. J. et al. (Ed.). Antimicrobial resistance in developing countries. New York: Springer, 2010.

SPRATT, B.G. Resistance to antibiotics mediated by target alterations. Science, v. 264, n. 5157, p. 388-393, 1994.

STINEAR, T. P. et al. Enterococcal vanB resistance locus in anaerobic bacteria in human faeces. Lancet, v. 357, n. 9259, p. 855-856, 2001. 
STROMMENGER, B. et al. Multiplex PCR assay for simultaneous detection of nine clinically relevant antibiotic resistance genes in Staphylococcus aureus. J. Clin. Microbiol., v. 41, n. 9, p. 4089-4094, 2003.

SU, J- Q. et al. Antibiotic resistome and its association with bacterial communities during sewage sludge composting. Environ. Sci. Technol. v. 49, n. 12, p. 73567363, 2015.

SURETTE, M. D.; WRIGHT, G. D. Lessons from the environmental antibiotic resistome. Annu. Rev. Microbiol. v. 71, p. 309-329, 2017.

SUTCLIFFE, J. et al. Detection of erythromycin-resistant determinants by PCR. Antimicrob. Agents Chemother., v. 40, n. 11, p. 2562-2566, 1996.

SWIFT, B. M. C. et al. Anthropogenic environmental drivers of antimicrobial resistance in wildlife. Sci. Total Environ. v. 649, p. 12-20, 2019.

SYED, M. A.; BANA, N. F. Developing countries need action plans to combat the challenge of antimicrobial resistance. Arch. Clin. Microbiol. v. 7, p. 12, 2016.

TEKINER, İ. H..; ÖZPINAR, H. Occurrence and characteristics of extended spectrum beta-lactamases-producing Enterobacteriaceae from foods of animal origin. Braz. J. Microbiol. v. 47, n. 2, p. 444-451, 2016.

THAKER, M.; SPANOGIANNOPOULOS, P.; WRIGHT, G. D. The tetracycline resistome. Cell. Mol. Life Sci. v. 67, n. 3, p. 419-431, 2010.

THAKUR, S.; GRAY, G. C.The Mandate for a Global "One Health" Approach to Antimicrobial Resistance Surveillance. Am. J. Trop. Med. Hyg. v. 100, n. 2, p. 227 , 2019.

THOMAS, C.M.; NIELSEN, K.M. Mechanisms of, and barriers to, horizontal gene transfer between bacteria. Nat. Rev. Microbiol., v. 3, n. 9, p. 711-721, 2005.

THOMAS, T.; GILBERT, J. E MEYER, F. Metagenômica - um guia de amostragem para análise de dados. Informática Microbiana e Experimentação, v. 2, n. 3, 2012.

TRZCINSKI, K. et al. Expression of resistance to tetracyclines in strains of methicillinresistant Staphylococcus aureus. J. Antimicrob. Chemother. v. 45, n. 6, p. 763-70, 2000.

TURPIN, W. et al. Lactobacilli as multifaceted probiotics with poorly disclosed molecular mechanisms. Int. J. Food Microbiol. v. 143, n. 3, p. 87-102, 2010.

TYAKHT, A. V. et al. Human gut microbiota community structures in urban and rural populations in Russia. Nat Commun. v. 4, n. 1, p. 1-9, 2013.

VAN DEN BUNT, G. et al. Prevalence, risk factors and genetic characterisation of extended-spectrum beta-lactamase and carbapenemase-producing Enterobacteriaceae (ESBL-E and CPE): a community-based cross-sectional study, the Netherlands, 2014 to 2016. Euro Surveill. v. 24, n. 41, p. 1800594, 2019. 
VAN DUIN, D.; DOI, Y..The global epidemiology of carbapenemase-producing Enterobacteriaceae.Virulence, v. 8, n. 4, p. 460-469, 2017.

VAN SCHAIK, W. The human gut resistome. Philos. Trans. R. Soc. Lond. B. Biol. Sci. v. 370, n. 1670, 2015.

VERSLUIS, D. et al. Mining microbial metatranscriptomes for expression of antibiotic resistance genes under natural conditions. Sci. Rep. v. 5, n. 1, p. 1-10, 2015.

VIKESLAND, P. et al. Differential Drivers of Antimicrobial Resistance across the World. Acc. Chem. Res. v. 52, n. 4, p. 916-924, 2019.

VON WINTERSDORFF, C. J. H. et al. Dissemination of antimicrobial resistance in microbial ecosystems through horizontal gene transfer. Front. Microbiol. v. 7, p. 173, 2016.

VOREADES, N.; KOZIL, A.; WEIR, T. L. Diet and the development of the human intestinal microbiome. Front. Microbiol. v. 5, p. 494, 2014.

WALSH, T. R. et al. Dissemination of NDM-1 positive bacteria in the New Delhi environment and its implications for human health: an environmental point prevalence study. Lancet Infect. Dis. v. 11, n. 5, p. 355-362, 2011.

WELLINGTON, E. M. et al. The role of the natural environment in the emergence of antibiotic resistance in Gram-negative bacteria. Lancet Infect. Dis. v. 13, n. 2, p. 155-165, 2013.

WEXLER, H. M. Bacteroides: the good, the bad, and the nitty-gritty. Clin. Microbiol. Rev. v. 20, n. 4, p. 593-621, 2007.

WHO, World Health Organization. Obesity: preventing and managing the global epidemic. Report of a WHO consultation on obesity. (WHO Technical Report Series n. 894). Geneva, Switzerland: WHO, 2000.

WHO, World Health Organization. The evolving threat of antimicrobial resistance: options for action. Geneva, 2012. Disponível em:

http://apps.who.int/iris/bitstream/10665/44812/ 1/9789241503181_eng.pdf (accessed Jan 17, 2015).

WHO, World Health Organization. Antimicrobial resistance: global report on surveillance. World Health Organization, 2014.

WHO, World Health Organization. Global antimicrobial resistance surveillance system (GLASS) report: early implementation 2020. Geneva, 2020. Disponível em: https://www.who.int/glass/resources/publications/early-implementation-report2020/en/

WONG, J. M. W. et al. Colonic health: fermentation and short chain fatty acids. J. Clin. Gastroenterol. v. 40, n. 3, p. 235-243, 2006. 
WOODFORD, N.; TURTON, J. F.; LIVERMORE, D.M. Multiresistant Gram-negative bacteria: the role of high-risk clones in the dissemination of antibiotic resistance. FEMS Microbiol. Rev. v. 35, n. 5, p. 736-755, 2011.

WOODFORD, N. et al. Multiplex PCR for genes encoding prevalent OXA carbapenemases in Acinetobacter spp. Int. J. Antimicrob. Agents, v. 27, n. 4, p. 351-353, 2006.

WRIGHT, G. D. Mechanisms of resistance to antibiotics. Curr. Opin. Chem. Biol. v. 7, n. 5, p. 563-569, 2003.

WU, G. D. et al. Linking long-term dietary patterns with gut microbial enterotypes.Science, v. 334, n. 6052, p. 105-108, 2011.

XAVIER, D.E. et al. Efflux pumps expression and its association with porin downregulation and $\beta$-lactamase production among Pseudomonas aeruginosa causing bloodstream infections in Brazil. BMC Microbiol., v. 10, n. 1, p. 217, 2010.

YONEDA, K. et al. Measurement of Pseudomonas aeruginosa multidrug efflux pumps by quantitative real-time polymerase chain reaction. FEMS Microbiol. Lett. v. 243, n. 1, p. 125-131, 2005.

ZAGO, M.; HUYS, G.; GIRAFFA, G. Molecular basis and transferability of tetracycline resistance in Enterococcus italicus LMG 22195 from fermented milk. Int. J. Food Microbiol. v. 142, n. 1-2, p. 234-236, 2010.

ZAHEER, R. et al. Comparative diversity of microbiomes and Resistomes in beef feedlots, downstream environments and urban sewage influent. BMC microbiol. v. 19, n. 1, p. 197, 2019.

ZHANG, C. et al. Impact of a 3-Months Vegetarian Diet on the gut Microbiota and immune repertoire. Front. Immunol. v. 9, p. 908, 2018.

ZHANG, K. et al.New quadriplex PCR assay for detection of methicillin and mupirocin resistance and simultaneous discrimination of Staphylococcus aureus from coagulase-negative Staphylococci. J. Clin. Microbiol. v. 42, n. 11, p. 4947-4955, 2004.

ZHOU, X. et al. Use of commercial organic fertilizer increases the abundance of antibiotic resistance genes and antibiotics in soil. Environ. Sci. Pollut. Res. v. 24, n. 1, p. 701-710, 2017a.

ZHOU, Y. et al. Occurrence, abundance, and distribution of sulfonamide and tetracycline resistance genes in agricultural soils across China. Sci. Total Environ. v. 599 , p. 1977-1983, $2017 b$.

ZIELIŃSKI, W. et al. Prevalence of Beta Lactamases Genes in Sewage and Sludge Treated in Mechanical-Biological Wastewater Treatment Plants. J. Ecol. Eng. v. 20, n. 9, 2019.

ZIMMER, J. et al. A vegan or vegetarian diet substantially alters the human colonic faecal microbiota. Eur. J. Clin. Nutr. v. 66, n. 1, p. 53-60, 2012. 


\section{ANEXO A - ARTIGO PUBLICADO}

Revista Antibiotics (ISSN: 2079-6382)

Fator de Impacto atual: 3,893

Classificação JCR:

23/93 (Q1) em 'Infectious Diseases'

64/270 (Q1) em 'Pharmacology \& Pharmacy' 


\title{
Influence of Human Eating Habits on Antimicrobial Resistance Phenomenon: Aspects of Clinical Resistome of Gut Microbiota in Omnivores, Ovolactovegetarians, and Strict Vegetarians
}

\author{
Suzane Fernandes da Silva, Isabela Brito Reis (D), Melina Gabriela Monteiro, Vanessa Cordeiro Dias (D), \\ Alessandra Barbosa Ferreira Machado, Vânia Lúcia da Silva and Cláudio Galuppo Diniz *D
}

check for updates

Citation: da Silva, S.F.; Reis, I.B.;

Monteiro, M.G.; Dias, V.C.; Machado, A.B.F.; da Silva, V.L.; Diniz, C.G. Influence of Human Eating Habits on Antimicrobial Resistance

Phenomenon: Aspects of Clinical

Resistome of Gut Microbiota in

Omnivores, Ovolactovegetarians, and Strict Vegetarians. Antibiotics 2021, 10 276. https://doi.org/10.3390/ antibiotics 10030276

Academic Editors: Mohammad Amjad Kamal and Firoz Anwar

Received: 14 February 2021

Accepted: 4 March 2021

Published: 9 March 2021

Publisher's Note: MDPI stays neutral with regard to jurisdictional claims in published maps and institutional affiliations.

Copyright: (c) 2021 by the authors. Licensee MDPI, Basel, Switzerland. This article is an open access article distributed under the terms and conditions of the Creative Commons Attribution (CC BY) license (https:// creativecommons.org/licenses/by/ $4.0 /)$.
Laboratory of Bacterial Physiology and Molecular Genetics, Center for Studies in Microbiology, Department of Parasitology, Microbiology and Immunology, Federal University of Juiz de Fora, 36036-330 Juiz de Fora, Brazil; sfs.fernandes@ufjf.br (S.F.d.S.); isabritoreis@ufjf.br (I.B.R.); melinamoreira84@gmail.com (M.G.M.); vanessa.dias@icb.ufjf.br (V.C.D.); alessandra.machado@icb.ufjf.br (A.B.F.M.); vania.silva@icb.ufjf.br (V.L.d.S.)

* Correspondence: claudio.diniz@icb.ufjf.br; Tel.: +55-32-2102-3213

Abstract: The use of xenobiotics in food production and how food intake is carried out in different cultures, along with different eating habits (omnivorism (ON), ovolactovegetarianism (VT), and strict vegetarianism (VG)) seem to have implications for antimicrobial resistance, especially in the human gut microbiota. Thus, the aim of this study was to evaluate aspects of the clinical resistome of the human gut microbiota among healthy individuals with different eating habits. Volunteers were divided into 3 groups: $n=19$ omnivores (ON), $n=20$ ovolactovegetarians (VT), and $n=19$ strict vegetarians (VG), and nutritional and anthropometric parameters were measured. Metagenomic DNA from fecal samples was used as a template for PCR screening of 37 antimicrobial resistance genes (ARG) representative of commonly used agents in human medicine. The correlation between eating habits and ARG was evaluated. There were no significant differences in mean caloric intake. Mean protein intake was significantly higher in $\mathrm{ON}$, and fiber and carbohydrate consumption was higher in VG. From the screened ARG, 22 were detected. No clear relationship between diets and the occurrence of ARG was observed. Resistance genes against tetracyclines, $\beta$-lactams, and the MLS group (macrolides, lincosamides, and streptogramins) were the most frequent, followed by resistance genes against sulfonamides and aminoglycosides. Vegetables and minimally processed foods seem to be the main source of ARG for the human gut microbiota. Although eating habits vary among individuals, the open environment and the widespread ARG from different human activities draw attention to the complexity of the antimicrobial resistance phenomenon which should be addressed by a One Health approach.

Keywords: clinical resistome; gut microbiota; eating habits; omnivorism; ovolactovegetarianism; strict vegetarianism

\section{Introduction}

The clinical resistome is defined as the set of genes related to antimicrobial resistance to drugs commonly used to treat infectious diseases in a particular environment $[1,2]$. The human gut microbiota is assumed to be an important reservoir of antimicrobial resistance genes (ARG), since it is always in contact with environmental microorganisms, which are introduced by oral contamination through food and water ingestion, and by contact with animals and other people. Horizontal transference of ARG may occur in the intestinal environment among commensal microorganisms, including potentially pathogenic ones, and pathogens $[3,4]$.

In light of the One Health concept, in which human health is linked to animal and environmental health [5], the microbiomes of humans, animals, and the different environments show a connection with each other, allowing ARG to be shared and widely 
distributed [6,7]. According to the historic perspective, the One Health concept has focused on local interconnections and interdependencies. As a contemporary point of view, this approach considers global health and includes the comprehension of characteristics that may stimulate the global antimicrobial resistance (AMR) [6].

Human activities may induce changes in the open environment and exert an important selective pressure on microbial communities, favoring the spread of ARG and contributing to the maintenance of, and even increase in, the antimicrobial resistance phenomenon [8,9].

It is accepted that the food production chain may play an important role in the selection and spread of ARG over the open environment, with food commensal or contaminant microorganisms being recognized as sources of ARG $[4,10]$. Although some studies show the role of food microorganisms in the spread of ARG with impacts on the human gut resistome, the influence of different eating habits on the phenomenon is still poorly understood [11-15]. Therefore, the objective of this study was to comparatively evaluate aspects of the clinical resistome of the gut microbiota considering different eating habits, namely, omnivorism $(\mathrm{ON})$, ovolactovegetarianism (VT), and strict vegetarianism (VG), and to investigate how food intake may contribute to resistome quality.

\section{Results}

The sociodemographic, anthropometric, and nutritional data of the participants are presented in Table 1. The average age of the participants was within the inclusion criteria and was overall $28.66( \pm 7.79)$ years old. Regarding ethnic groups, $72.4 \%$ were White and $19.0 \%$ were Pardo. Less than 10\% belonged to other ethnic groups (Black and East Asian $-6.9 \%$ and $1.7 \%$, respectively), and the average BMI was 21.90 . With regards to the gender distribution, $25.9 \%$ were male and $74.1 \%$ were female. No significant differences were observed in daily caloric intake; however, the lipid consumption was higher in ON compared with VG. Regarding protein intake, consumption was different between the three groups, being higher in omnivores. Carbohydrate consumption was significantly higher among VG than in the other two groups, and there were no significant differences between $\mathrm{ON}$ and VT. Regarding the consumption of total fibers, insoluble fibers, and soluble fibers, the three groups behaved differently, with fiber consumption in VG being higher than in the other two groups, and the eating behavior of ON participants showing the lowest fiber consumption.

Table 1. Sociodemographic, anthropometric, and nutritional characteristics of the participants.

\begin{tabular}{|c|c|c|c|c|c|}
\hline \multirow{2}{*}{\multicolumn{2}{|c|}{ Characteristics }} & \multicolumn{3}{|c|}{ Group of Participants According to Their Eating Habits } & \multirow{2}{*}{$p<0.05 *$} \\
\hline & & ON $(n=19)$ & VT $(n=20)$ & VG $(n=19)$ & \\
\hline \multicolumn{2}{|c|}{ Gender (\%; male/female) } & $15.8 / 84.2$ & $20.0 / 80.0$ & $42.1 / 57.9$ & na \\
\hline \multicolumn{2}{|c|}{ Average age (years \pm SD) } & $28.47 \pm 6.02$ & $31.63 \pm 9.72$ & $25.89 \pm 6.24$ & na \\
\hline \multirow{4}{*}{ Ethnic Group (\%) } & White & 52.6 & 78.9 & 89.5 & na \\
\hline & Pardo ** & 31.6 & 10.6 & 10.5 & na \\
\hline & Black & 10.5 & 10.5 & & na \\
\hline & East Asian & 5.3 & & & na \\
\hline Average BM & an \pm SD) & $21.46 \pm 1.96$ & $22.13 \pm 1.95$ & $22.12 \pm 1.72$ & \\
\hline Mean daily calor & ake $(\% \pm \mathrm{SD})$ & $2049.3 \pm 836.1$ & $2092.4 \pm 738.9$ & $2522.7 \pm 955.2$ & \\
\hline Mean daily lipi & ke $(\% \pm \mathrm{SD})$ & $33.39 \pm 6.07$ & $33.64 \pm 14.41$ & $25.10 \pm 12.11$ & c \\
\hline Mean daily prote & take (\% $\pm \mathrm{SD})$ & $19.22 \pm 4.80$ & $12.10 \pm 3.16$ & $10.17 \pm 1.91$ & $a, b, c$ \\
\hline Mean daily CAR & ake $(\% \pm \mathrm{SD})$ & $47.39 \pm 7.35$ & $54.26 \pm 13.95$ & $64.73 \pm 11.34$ & $\mathrm{~b}, \mathrm{c}$ \\
\hline Mean daily $\mathrm{TH}$ & ke $(g \pm S D)$ & $23.01 \pm 9.04$ & $41.98 \pm 25.12$ & $63.78 \pm 35.79$ & $a, b, c$ \\
\hline Mean daily SF & кe $(g \pm S D)$ & $2.53 \pm 1.56$ & $4.98 \pm 2.53$ & $13.58 \pm 14.65$ & $a, b, c$ \\
\hline Mean daily IF & $\mathrm{e}(\mathrm{g} \pm \mathrm{SD})$ & $5.14 \pm 3.27$ & $8.88 \pm 5.41$ & $21.42 \pm 19.36$ & $a, b, c$ \\
\hline
\end{tabular}

* Significant statistical analysis, $p$-value was determined by Student's $t$-test: a: comparison between ON and VT; b: comparison between VT and VG; c: comparison between ON and VG. ${ }^{* *}$ The ethnic group Pardo is used in Brazil to refer to people of mixed ethnic ancestries and represents a diverse range of ethnic backgrounds. BMI = Body Mass Index; CARB = carbohydrates; TF = total fibers; $\mathrm{SF}=$ soluble fibers; $\mathrm{IF}=$ insoluble fibers. $\mathrm{ON}=$ omnivores; $\mathrm{VT}=$ ovolactovegetarians; $\mathrm{VG}=$ strict vegetarians. $\mathrm{SD}=$ standard deviation. na $=$ not applicable. 
From the 37 tested ARG, representative of the clinical resistome considering the most widely used antimicrobials in human medicine, 22 were detected at least in one group of individuals. Among the ARG detected, tetracycline resistance genes were the most observed among the three groups, followed by macrolide, lincosamide, and streptogramin (MLS) and macrolide resistance genes and $\beta$-lactam resistance genes (Figure 1). The tet (M), tet $(Q)$, and tet $(O)$ genes and $\operatorname{erm}(B)$ were detected in all samples analyzed. bla $a_{T E M}$ and mef were detected at a frequency higher than $70 \%$ in the three groups. aacA-aphD was also frequently detected, ranging from $37 \%$ in VG to $55 \%$ in VT. The sulfonamide resistance genes, sul1 and sul2, quinolone resistance genes, qnrB and qnrS, and intl-1 genes had intermediate detection frequencies (Figure 2). Fifteen common markers were observed among all evaluated groups. ARG such as qnrS and intl-2 were found only in ON and VT, while $\operatorname{erm}(A)$ and tet $(L)$ were specifically detected in ON and VG; blaZ was observed in VT and VG, whereas bla $a_{C T X-M}$ was detected in a single sample from the VT group and tet $(E)$ detected in only one sample from the ON group (Figure 3).

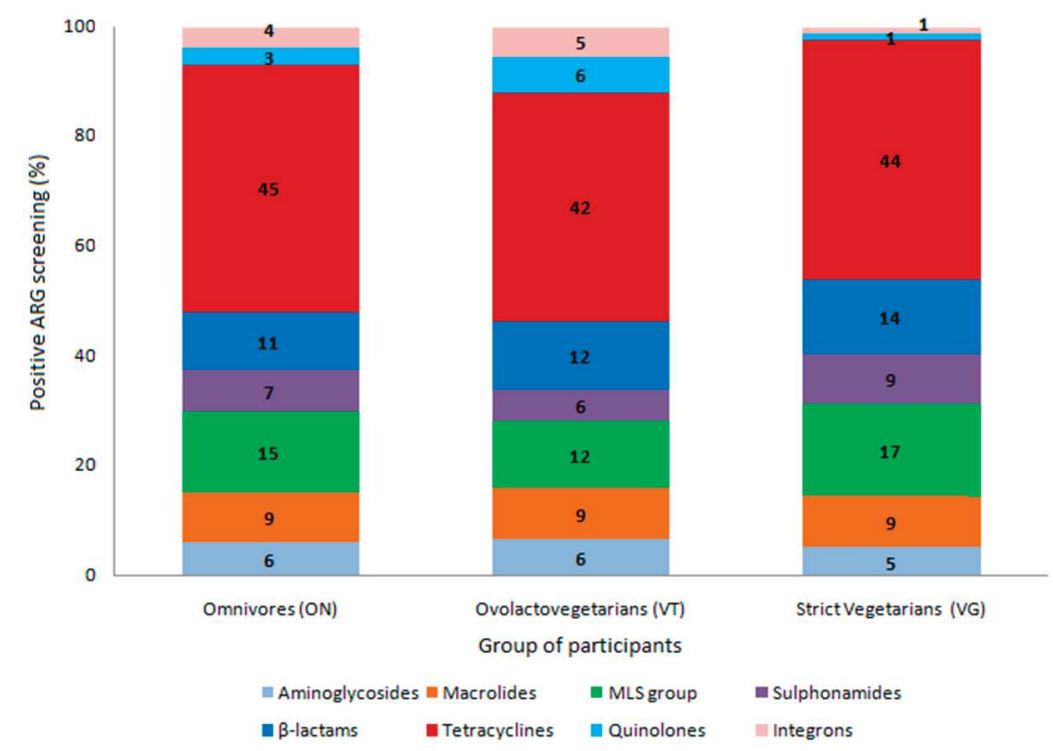

Figure 1. Frequency of detection of antimicrobial resistance genetic markers (ARG) related to different classes of antimicrobial drugs according to positive screening by PCR from the fecal metagenome of omnivores (ON), ovolactovegetarians (VT), and strict vegetarians (VG). ARG are clustered based on their chemical structure or phenotype, such as $\beta$-lactams $\left(b l a_{C T X-M}, b l a_{T E M}, b l a_{S H V}, b l a Z, m e f\right)$; tetracyclines $(\operatorname{tet}(A), \operatorname{tet}(B), \operatorname{tet}(E), \operatorname{tet}(L), \operatorname{tet}(M), \operatorname{tet}(O), \operatorname{tet}(Q)) ;$ macrolide, lincosamide, and streptogramin (MLS) group (ermA, ermB, erm C); quinolones ( $q n r B, q n r S)$; sulfonamides (sul1, sul2); aminoglycosides (aacA-aphD); and integrons (intl-1, intl-2). 


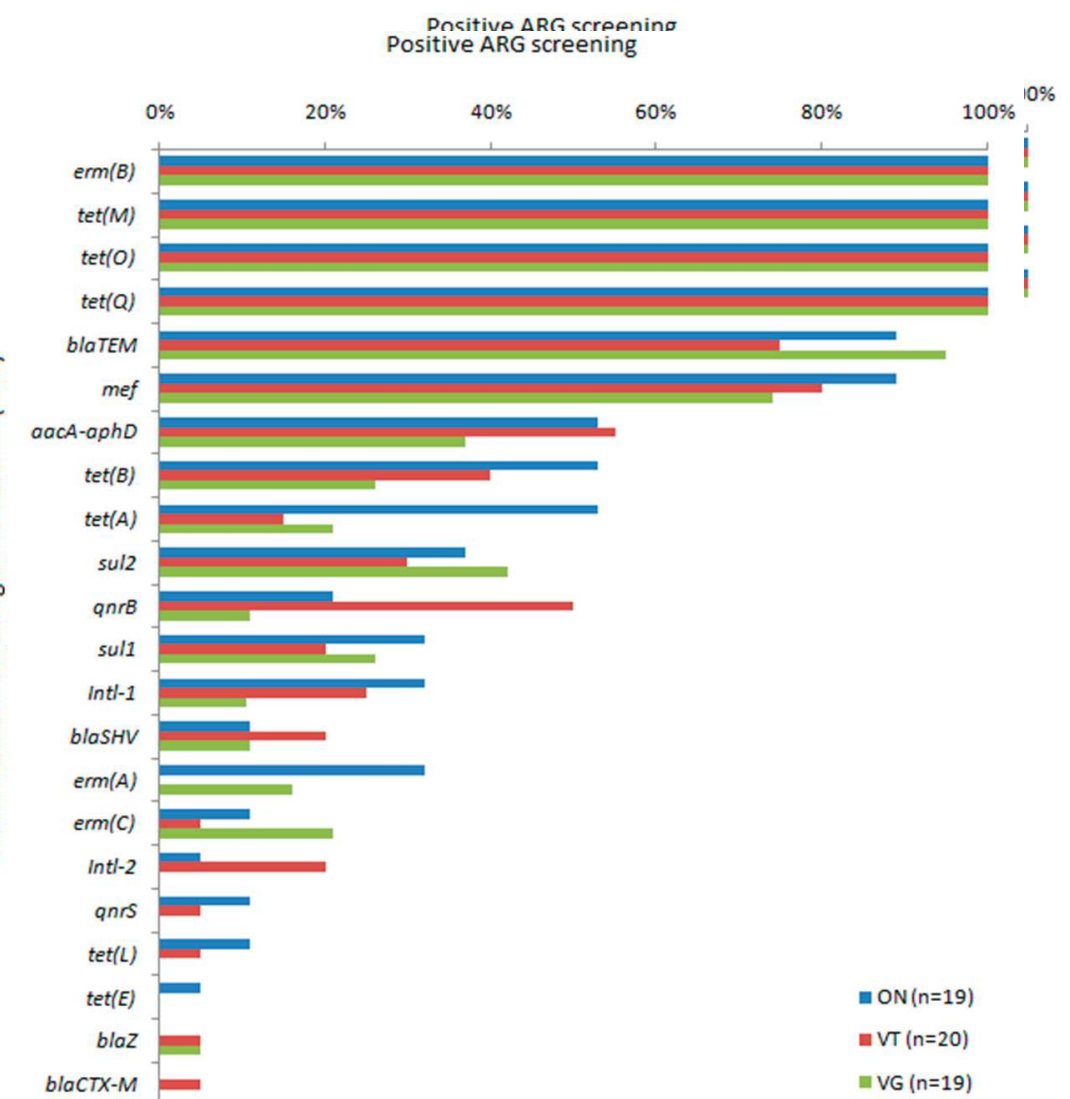

Figure 2. Distribution of 22 antimicrobial resistance genetic markers (ARG) detected out of 37 tested by PCR from the fecal metagenome of omnivores (ON), ovolactovegetarians (VT), and strict vegetarians (VG). Frequency of positive screening among each tested sample.

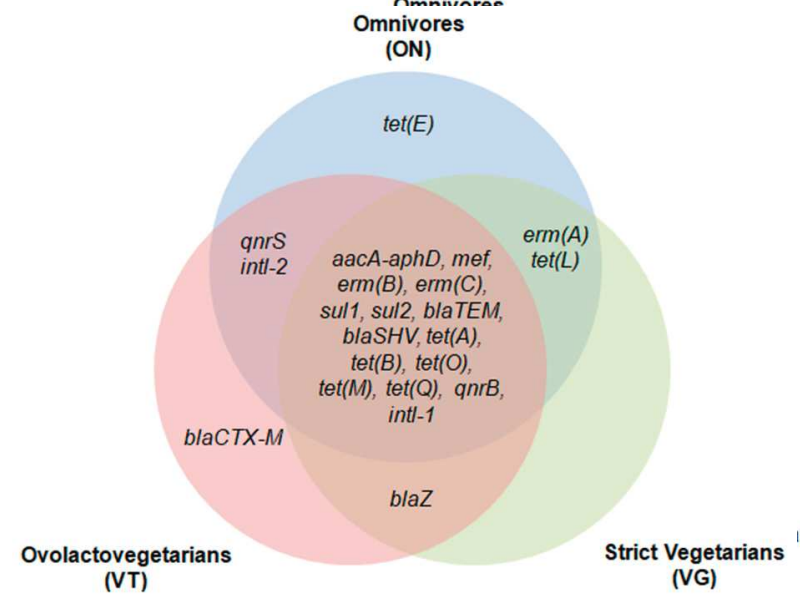

Figure 3. Venn diagram representing the occurrence of antimicrobial resistance genetic markers (ARG) and qualitative clustering according to their positive screening exclusively or shared between omnivores (ON), ovolactovegetarians (VT), and strict vegetarians (VG). $\beta$-lactams (bla $a_{C T X-M}, b l a_{T E M}$, $\left.b_{S H V}, b l a Z, m e f\right)$; tetracyclines $(\operatorname{tet}(A), \operatorname{tet}(B), \operatorname{tet}(E), \operatorname{tet}(L), \operatorname{tet}(M), \operatorname{tet}(O), \operatorname{tet}(Q))$; macrolide lincosamide and streptogramin (MLS) group (ermA, ermB, erm C); quinolones (qnrB, qnrS); sulfonamides (sul1, sul2); aminoglycosides (aacA-aphD); and integrons (intl-1, intl-2).

Taking together the ARG screening data considering the three different groups of individuals with specific eating habits, a highly homogeneous distribution of detected genetic markers was observed among the ON, VT, and VG. No significant clustering was observed in the similarity matrix and dendrogram obtained. Although two clusters were 
observed considering a threshold of similarity between $65 \%$ and $70 \%$, no differentiation was observed within each cluster considering the participants in the study. The data support the observation that different eating habits may not influence the distribution of ARG in the human gut microbiota from a holistic point of view (Figure 4).

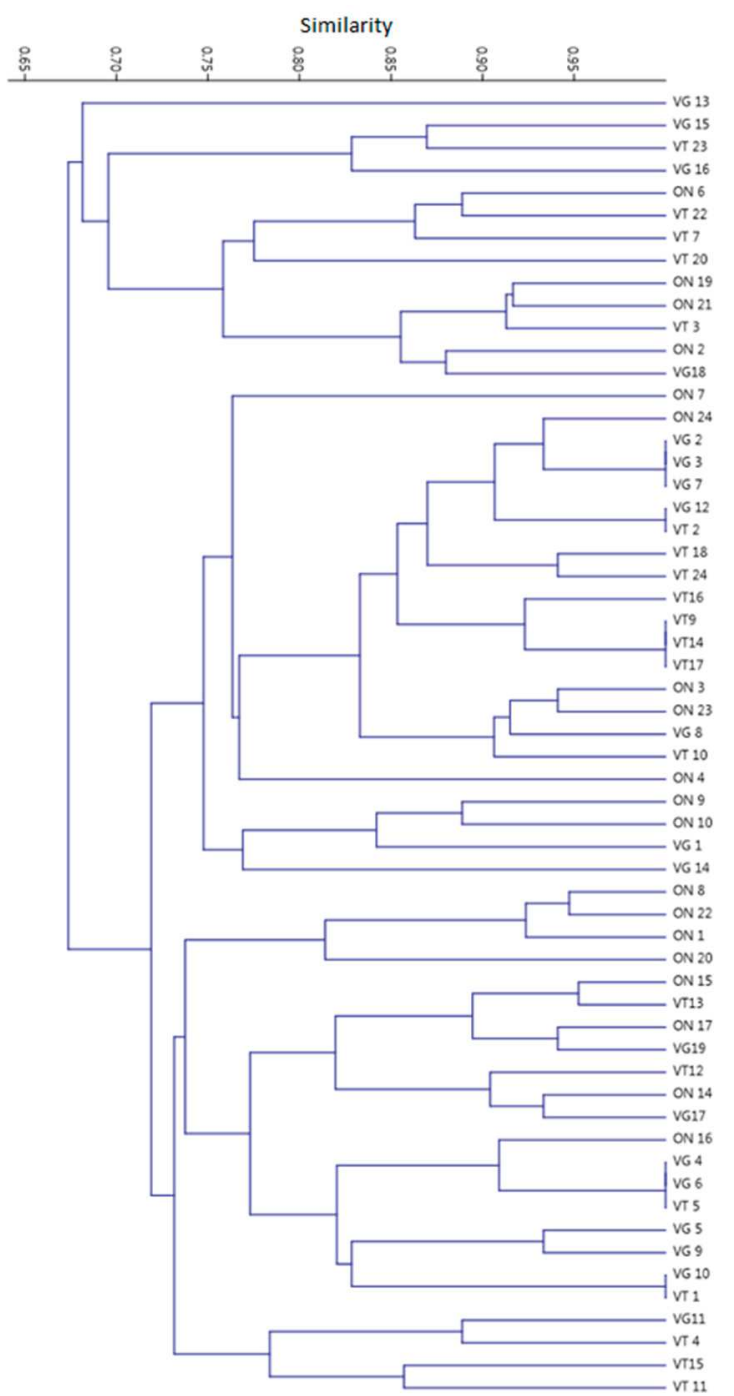

Figure 4. Clustering analysis of 58 healthy individuals with different eating habits (omnivores (ON), ovolactovegetarians (VT), and strict vegetarians (VG)) related to polymerase chain reaction (PCR) screening of antimicrobial resistance genes (ARG), representative of the human gut clinical resistome. The dendrogram was obtained from a binary matrix built based on positive or negative amplification of each tested ARG, using the Unweighted Pair Group Method with Arithmetic Mean (UPGMA) grouping method.

\section{Discussion}

Recently, issues related to antimicrobial resistance have changed as scientific information is gained regarding the origin, transmission, and evolution of the phenomenon. However, the interplay among humans, animals, and the environment in this context, including human activities, has not been completely elucidated [6]. Geography and behavior are among the key factors related to the human microbiota structure, although the microbial core is specific in different species $[7,8]$. In this regard, biotic and abiotic environmental factors are accepted to modulate a microorganism's distribution in different ecosystems, especially considering the One Health approach. It is expected that the One Health approach will modify concepts to improve our understanding of ARG transmission 
and guide strategies to mitigate AMR [6]. Anthropogenic activities and habits such as eating behavior, culture, practices of antimicrobial use in different activity levels, sanitation, hygiene, and waste management have a impact on microbiota diversity as well as on ARG distribution, especially in the gut microbiota $[8,16,17]$. In addition, it is accepted that environmental resistomes may share a common core which is available to humans and other animals [6,18].

In this longitudinal and prospective study with a probabilistic sample of an average population representative of healthy Brazilians, all of them adult residents in urban areas with different eating habits, no significant differences were observed in the anthropometrical data, clearly supporting that nutritional habits were more likely related to eventual alterations in intestinal microbiota structure, more specifically the gut microbiota resistome. Considering eventual bias related to ethnic groups and their social behavior, it is difficult to address any discussion as most of the participants belonged to the White ethnic group followed by Pardo. The term Pardo is a particularly complex one and is used in Brazil to refer to people of mixed ethnic ancestries and social behavior [19]. Considering the other populational characteristics such as healthy status and being a resident of the same urban area, no differences were observed considering ethnicity. The observed predominance of fiber intake in VT and VG diets compared with ON may suggest that foods with a lower degree of processing, especially vegetables, may be considered the main source of ARG in these individuals, with a low impact of food from animal origin on microbial resistome quality. However, according to the literature, and as observed in the wide distribution of ARG, it is reasonable to suggest an interchange among human, animal, and plant microbiomes, as ARG related to antimicrobials used in veterinary medicine were detected in the gut resistome of VG individuals [6,7].

As for ON, foodstuffs of animal and plant origin are likely to contribute to the resistome composition. In contrast, for VT and VG, it is highly suggested that vegetableassociated microorganisms are the main source for ARG to build the gut resistome. It is important to reinforce that our data showed an overall similar final composition in ON, VT, and VG gut clinical resistomes. A homogeneous distribution of volunteers' samples was observed with no clustering related to eating habits. From a different point of view, some authors state that overall resistome composition is not significantly impacted by diet; however, they suggest that meat and animal-derived foods may carry more ARG [7,20]. It must be stressed that in these reports geographical locations are different, and the numbers of screened ARG are lower than in our study along with inclusion and exclusion criteria, which may explain the non-uniform information drawn from the data.

On the other hand, ARG can remain stable in the human gut microbiota for long periods, even in the absence of antimicrobial selection [21]. Thus, ARG diversity is due not only to the direct effect of the selective pressure exerted by antimicrobial use, but also to transference of ARG between different microbiomes. Several studies have already highlighted the role of fecal contamination in the process of ARG spread, showing high prevalence of ARG in animal and human feces, sewage waste, and water treatment plants. Through soil and irrigation water, ARG may reach vegetables $[6,22,23]$.

The plant microbiome shares ARG with the surrounding environment, and soil is probably the main ARG source for the resistome in plants [24]. As vegetables are usually eaten raw or with low processing, the chances of antimicrobial resistant bacteria and ARG remaining viable and reaching the human gut microbiota are greater [24-26]. Several studies have shown that organic vegetables have a richer resistome when compared with conventional ones, suggesting that the consumption of organic vegetables is also an important source of ARG for the human microbiota [27-30].

Tetracyclines, macrolides, $\beta$-lactams, and sulfonamides are among the most used antimicrobials in farm animals [31,32]. They can be used to treat infections, for prophylaxis, metaphylaxis, and, in low doses, as growth promoters. In Brazil, the use of several antimicrobials as growth promoters was banned in the early 2000s. However, the consumption of these drugs remains high, and it is estimated that in Brazil and in the other BRICS countries, 
antimicrobial consumption will double in livestock activities by the year 2030. Despite the ban, use of prophylaxis and metaphylaxis remains high [33,34].

ARG such as tet $(Q)$ and tet $(O)$ are frequently detected in farm animal feces and are shown to be a stable part of their gut resistome. These tet genes are commonly associated with transposons and mobile genetic elements, which may contribute to their wide distribution among environments [35]. Variants such as tet $(Q)$, tet $(O)$, and tet $(M)$ are highly frequent genes in the human gut resistome [22]. It is known that tet $(Q)$ is highly prevalent among isolates of Bacteroides spp., major anaerobic bacilli resident in the human gut microbiota. As for erm genes, they are also commonly found in healthy individuals, showing homology to alleles in different species, which may suggest horizontal spread [35-37]. Still, according to the literature, tet transcripts could play several additional roles, such as cell signaling, communication, or transport. Besides, toxic heavy metals and antimicrobials of the MLS group could participate in co-selection of tetracycline resistance [22,38,39].

The MLS group of ARG is usually detected in the environment related to human and animal microbiota, soil, water, and sewage $[18,23,40]$. Among them, $\operatorname{erm}(B)$ is the most common and highly frequent in the human gut microbiota and is associated with mobile genetic elements $[18,23,40-42]$. As for mef, also highly detected in the present study, they encode efflux pumps, and are commonly associated with transposons [42,43].

$b l a_{T E M}$, an important extended-spectrum beta-lactamase (ESBL) encoding gene, was the main beta-lactamase-related ARG detected in this study, corroborating other authors who describe $b l_{T E M}$ in human feces, animal origin foodstuffs, and sewage [31,44-46]. The bla $a_{T E M}$ genes, together with other ARG related to macrolide, aminoglycoside, and tetracycline resistance, are accepted to be widely spread [18]. In fact, the aacA-aphD gene, reported to be an important aminoglycoside ARG, was also among the most observed in this study.

Although some reports have described lower observation of $b a_{T E M}$ and higher detection of bla $C T X-M$ and variants in human and animal feces and foodstuffs [20,47-49], the low bla $_{C T X-M}$ detection in this study raises some considerations: ARG persistency in each environment should be directly impacted by antimicrobial use and ESBL-producing bacteria epidemiology, including geography, movement of people, trade, and social behavior [50]. In Brazil, high detection rates of bla in both eutrophic, overweight, and obese volunteers, which may reinforce the role of local epidemiology as a feature related to ARG persistency in different regions [31].

Sulfonamide and quinolone ARG were also observed but to a lesser extent when compared with tetracycline, MLS, and macrolide genes, with sul1 and most of all sul2 genes being detected in all groups, considering the different eating habits. There is evidence of sul gene spread throughout water, soil, human and animal feces, vegetables, low processed foods, and sewage [32,51-54]. These antimicrobials, along with tetracyclines and penicillins, are often used in veterinary medicine. In addition, they seem to be highly persistent in soil, sediments, and water, due to properties such as high soil penetration and low removal efficiency, like tetracyclines [32].

Quinolone ARG such as qnrB and qnrS were also observed. Although the most common mechanism of quinolone resistance is chromosomal mutations, plasmid-mediated resistance can occur and is mainly related to qnr genes [55-57]. These genes confer low levels of resistance when compared to chromosomal resistance but may be horizontally transferred. In different ecossystems such as aquatic environments, livestock or human resistomes, more than one quinolone ARG may be observed in a mobile genome [55,56,58,59].

As described elsewhere, ARG are often associated with mobile genetic elements, mainly class 1, but also class 2 and 3 integrons [60]. In this study, intl-1 was the most detected in all tested groups, in higher frequencies for ON and VT. Although intl-2 was also detected, but at a lower frequency, it was not observed in the fecal metagenome of VG participants. Facing the frequency of observation and the core of ARG among the three groups of participants, it is reasonable to suggest that although integrons play an important role in ARG spread by horizontal transference, especially class 1, other mobile 
genetic elements, such as transposons and plasmids, also have an important role in ARG transfer in the gut microbiota. Further prospective studies are thus needed to map and better address the ARG transference routes in the gut microbiota.

\section{Materials and Methods}

\subsection{Study Design}

This a descriptive cross-sectional study with healthy volunteers, $n=58$, resident in the southeast region of Brazil, with different eating habits (ON, $n=19$; VT, $n=20$; and VG, $n=19$ ), invited to participate. The inclusion criteria were: (i) age ranging between 18 and 60 years old; (ii) dietary behavior for at least one year; (iii) body mass index (BMI) between 18.5 and 24.9; (iv) no antimicrobial agent intake in the past 3 months; (v) no pregnancy or breastfeeding; and (vi) no chronic diseases such as systemic pathologies, diabetes, hypertension, cancer, and rheumatoid arthritis. The study was approved by the Human Research Ethics Committee of the Federal University of Juiz de Fora. All volunteers were informed about the study and signed the Free and Informed Consent Form.

\subsection{Participants' Anthropometric Data and Dietary Assessment}

Volunteers' weight was measured on a digital scale in a central position, erect, barefoot, with feet together, and wearing as little clothing as possible. Height was measured by means of a vertical stadiometer attached to the scale, with the volunteer also barefoot and erect, with heels together, with no headdress and looking at the horizon. BMI was calculated based on the relationship between weight and height $\left(\mathrm{Kg} / \mathrm{m}^{2}\right)$ and evaluated according to the method proposed by the World Health Organization [61]. To reduce variation, the measures were always measured by the same person, using the same tape measure and scale.

Regular food intake was accessed by a quantitative food frequency questionnaire (QFFQ), according to the literature [62]. In these questionaries, the volunteers recorded the average food intake (daily, weekly, and monthly) in the past six months. A literaturevalidated photographic album was used to estimate food portion sizes [63].

\subsection{Fecal Specimen Collection and Storage}

After dietary assessment, stool samples were collected by spontaneous demand, fresh in its native state in a screw-cap sterile container, and transported to the laboratory within two hours in an ice box to be processed for metagenomic DNA extraction from $200 \mathrm{mg}$ aliquots. Reminiscent stool samples were stored in a freezer at $-80^{\circ} \mathrm{C}$.

\subsection{Extraction, Quantitation, and Integrity of Metagenomic DNA}

The metagenomic DNA was extracted using the commercial kit QIAamp ${ }^{\mathrm{TM}}$ Fast DNA Stool Mini Kit (Qiagen, Hilden, Germany), according to the manufacturer's instructions. Further, extracted DNA was eluted in a volume of $50 \mu \mathrm{L}$ and kept in a freezer at $-20{ }^{\circ} \mathrm{C}$ for further analysis. Metagenomic DNA quantification and purity were determined by the A260/ A280 absorbance ratio with Nanodrop (Thermo Scientific NanoDrop ${ }^{\mathrm{TM}} 2000$ micro volume spectrophotometer, Thermo Fisher Scientific, Waltham, MA, USA).

DNA integrity was assessed by electrophoresis on $0.8 \%$ agarose gel in $0.5 \mathrm{X}$ TBE buffer (Tris-HCl-Borate-EDTA). The gel was stained with ethidium bromide and analyzed in an ultraviolet light transilluminator (GE Healthcare, Amersham, UK).

\subsection{Screening of Antimicrobial Resistance Genes (ARG)}

The clinical resistome assessed in this study consists of a set of 37 ARG, including classes 1, 2, and 3 integrons (Table S1, Supplementary Data). These resistance markers were PCR screened from metagenomics with specific primers and amplification conditions as previously described in the literature (Table S1, Supplementary Data).

The PCR reactions were performed in $25 \mu \mathrm{L}$ containing $12.5 \mu \mathrm{L}$ of PCR Master Mix (Promega, Madison, WI, USA) and $1 \mu \mathrm{L}$ of DNA ( $20 \mathrm{ng} / \mu \mathrm{L})$. Primer volumes varied 
according to the ARG, and the total volume was completed with water. The reactions took place in an automated thermocycler (Biometra T1 Thermocycler, Gttingen, Germany), according to different running protocols, specific for each primer set (Table S1, Supplementary Data). After PCR reaction, electrophoresis was performed on $1.0 \%$ agarose gel, analyzed after ethidium bromide staining on an ultraviolet transilluminator (GE Healthcare, Amersham, UK). A molecular weight standard $1 \mathrm{~Kb}$ DNA ladder (Promega, Madison, WI, USA) was used. Positive and negative controls were used for each PCR reaction.

\subsection{Statistical Analysis}

Student's $t$-test was used to compare the macronutrient intake from the QFFQ, with a significance level of $5 \%(p=0.05)$ and using the XLSTAT statistical program. To evaluate the clinical resistome similarity clustering according to the presence or absence of ARG detection, a dendrogram was constructed based on Dice similarity coefficient and UPGMA method (Unweighted Pair Group Method with Arithmetic Averages).

\section{Conclusions}

Human activities have a strong impact on microbiomes in different environments, with special concern for antimicrobial drug use. Although low processed foods might be considered an important source of ARG for resident microbiota, such as intestinal bacteria, there are several variables that may contribute to human gut resistome content which are still not entirely clear. In general, the results observed may suggest that vegetables and minimally processed foods are highly related to the core gut clinical resistome. In this study, healthy volunteers were screened for ARG from the fecal metagenome, with mostly different eating habits. On the other hand, from a One Health perspective, although vegetable and low processed food intake is thought to be the most common behavior in the sampled population, sources of ARG still may vary between different individuals. The ARG distribution in the environment seems to be so worrisome and widespread that eating habits may not be the only source of genetic elements and selective pressures that may impact the human gut resistome. Facing the relevance of antimicrobial resistance, further studies are needed to better address this issue in order to provide information support to the implementation of public and environmental policies to help to control the phenomenon.

Supplementary Materials: The following are available online at https://www.mdpi.com/2079-6 382/10/3/276/s1, Table S1: Resistance genetic markers screened, initiator oligonucleotides, size of expected amplicons, and references.

Author Contributions: Conceptualization, C.G.D. and V.L.d.S.; methodology, C.G.D., S.F.d.S., I.B.R., and M.G.M.; validation, V.C.D. and A.B.F.M.; formal analysis, C.G.D., V.L.d.S., and S.F.d.S.; investigation, C.G.D., S.F.d.S., I.B.R., and M.G.M.; resources, C.G.D. and V.L.d.S.; Writing-Original draft preparation, S.F.d.S., V.L.d.S., and C.G.D.; Writing-Review and editing, S.F.d.S., V.L.d.S., A.B.F.M., and C.G.D. All authors have read and agreed to the published version of the manuscript.

Funding: This research was funded by CNPq, FAPEMIG, and PROQUALI/UFJF.

Institutional Review Board Statement: The study was conducted according to the guidelines of the Declaration of Helsinki, and approved by the Ethics Committee of Universidade Federal de Juiz de Fora (UFJF) (protocol code ${ }^{\circ} 2.046 .122$, approved on 4 May 2017).

Informed Consent Statement: Informed consent was obtained from all subjects involved in the study.

Acknowledgments: This work was done at the Laboratory of Physiology and Bacterial Molecular Genetics. The authors gratefully acknowledge the financial support of the Fundação de Amparo a Pesquisa do Estado de Minas Gerais (FAPEMIG) and Conselho Nacional de Desenvolvimento Científico e Tecnológico (CNPq). We thank all the participants who generously volunteered and participated in this project.

Conflicts of Interest: The authors declare no conflict of interest. 


\section{References}

1. Gillings, M.R. Evolutionary consequences of antibiotic use for the resistome, mobilome and microbial pangenome. Front. Microbiol. 2013, 4, 4. [CrossRef]

2. Ho, J.; Yeoh, Y.K.; Barua, N.; Chen, Z.; Lui, G.; Wong, S.H.; Yang, X.; Chan, M.C.; Chan, P.K.; Hawkey, P.M.; et al. Systematic review of human gut resistome studies revealed variable definitions and approaches. Gut Microbes 2020, 12, 1-12. [CrossRef]

3. Baquero, F. Metagenomic epidemiology: A public health need for the control of antimicrobial resistance. Clin. Microbiol. Infect. 2012, 18, 67-73. [CrossRef] [PubMed]

4. Caniça, M.; Manageiro, V.; Abriouel, H.; Moran-Gilad, J.; Franz, C.M. Antibiotic resistance in foodborne bacteria. Trends Food Sci. Technol. 2019, 84, 41-44. [CrossRef]

5. Destoumieux-Garzón, D.; Mavingui, P.; Boetsch, G.; Boissier, J.; Darriet, F.; Duboz, P.; Fritsch, C.; Giraudoux, P.; Le Roux, F.; Morand, S.; et al. The One Health Concept: 10 Years Old and a Long Road Ahead. Front. Vet. Sci. 2018, 5, 14. [CrossRef] [PubMed]

6. Kim, D.W.; Cha, C.J. Antibiotic resistome from the One-Health perspective: Understanding and controlling antimicrobial resistance transmission. Exp. Mol. Med. 2021, 1-9. [CrossRef]

7. Milanović, V.; Osimani, A.; Aquilanti, L.; Tavoletti, S.; Garofalo, C.; Polverigiani, S.; Litta-Mulondo, A.; Cocolin, L.; Ferrocino, I.; Di Cagno, R.; et al. Occurrence of antibiotic re-sistance genes in the fecal DNA of healthy omnivores, ovo-lacto vegetarians and vegans. Mol. Nutr. Food Res. 2017, 61, 1601098. [CrossRef]

8. Gillings, M.R.; Paulsen, I.T.; Tetu, S.G. Ecology and Evolution of the Human Microbiota: Fire, Farming and Antibiotics. Genes 2015, 6, 841-857. [CrossRef]

9. Swift, B.M.C.; Bennett, M.; Waller, K.; Dodd, C.; Murray, A.; Gomes, R.L.; Humphreys, B.; Hobman, J.L.; Jones, M.A.; Whitlock, S.E.; et al. Anthropogenic environmental drivers of anti-microbial resistance in wildlife. Sci. Total Environ. 2019, 649, 12-20. [CrossRef] [PubMed]

10. Koch, B.J.; Hungate, B.A.; Price, L.B. Food-animal production and the spread of antibiotic resistance: The role of ecology. Front. Ecol. Environ. 2017, 15, 309-318. [CrossRef]

11. Levy, S.B.; Fitzgerald, G.B.; Macone, A.B. Changes in Intestinal Flora of Farm Personnel after Introduction of a TetracyclineSupplemented Feed on a Farm. N. Engl. J. Med. 1976, 295, 583-588. [CrossRef] [PubMed]

12. Levy, S.B.; Fitzgerald, G.B.; Macone, A.B. Spread of antibiotic-resistant plasmids from chicken to chicken and from chicken to man. Nat. Cell Biol. 1976, 260, 40-42. [CrossRef]

13. Looft, T.; Johnson, T.A.; Allen, H.K.; Bayles, D.O.; Alt, D.P.; Stedtfeld, R.D.; Sul, W.J.; Stedtfeld, T.M.; Chai, B.; Cole, J.R.; et al. In-feed antibiotic effects on the swine intestinal micro-biome. Proc. Natl. Acad. Sci. USA 2012, 109, 1691-1696. [CrossRef] [PubMed]

14. Amador, P.; Fernandes, R.; Prudêncio, C.; Duarte, I. Prevalence of Antibiotic Resistance Genes in Multidrug-Resistant Enterobacteriaceae on Portuguese Livestock Manure. Antibiotics 2019, 8, 23. [CrossRef] [PubMed]

15. Abriouel, H.; Knapp, C.W.; Gálvez, A.; Benomar, N. Chapter 29-Antibiotic Resistance Profile of Microbes from Traditional Fermented Foods. In Fermented Foods in Health and Disease Prevention; Frias, J., Martinez-Villaluenga, C., Peñas, E., Eds.; Academic Press: Boston, MA, USA, 2017; pp. 675-704.

16. Forslund, K.; Sunagawa, S.; Kultima, J.R.; Mende, D.R.; Arumugam, M.; Typas, A.; Bork, P. Country-specific antibiotic use practices impact the human gut resistome. Genome Res. 2013, 23, 1163-1169. [CrossRef] [PubMed]

17. Lee, K.; Kim, D.-W.; Lee, D.-H.; Kim, Y.-S.; Bu, J.-H.; Cha, J.-H.; Thawng, C.N.; Hwang, E.-M.; Seong, H.J.; Sul, W.J.; et al. Mobile resistome of human gut and pathogen drives anthro-pogenic bloom of antibiotic resistance. Microbiome 2020, 8, 2. [CrossRef]

18. Pal, C.; Bengtsson-Palme, J.; Kristiansson, E.; Larsson, D.G.J. The structure and diversity of human, animal and environmental resistomes. Microbiome 2016, 4, 1-15. [CrossRef]

19. Nobles, M. History counts: A comparative analysis of racial/color categorization in US and Brazilian censuses. Am. J. Public Health 2000, 90, 1738-1745. [CrossRef]

20. LoSasso, C.; Di Cesare, A.; Mastrorilli, E.; Patuzzi, I.; Cibin, V.; Eckert, E.M.; Fontaneto, D.; Vanzo, A.; Ricci, A.; Corno, G.; et al. Assessing antimicrobial resistance gene load in vegan, vegetarian and omnivore human gut microbiota. Int. J. Antimicrob. Agents 2018, 52, 702-705. [CrossRef]

21. Versluis, D.; D'Andrea, M.M.; Garcia, J.R.; Leimena, M.M.; Hugenholtz, F.; Zhang, J.; Ozturk, B.; Nylund, L.; Sipkema, D.; Van Schaik, W.; et al. Mining microbial metatranscriptomes for expression of antibiotic resistance genes under natural conditions. Sci. Rep. 2015, 5, 11981. [CrossRef]

22. Singh, S.; Verma, N.; Taneja, N. The human gut resistome: Current concepts \& future prospects. Indian J. Med Res. 2019, 150, 345-358. [CrossRef] [PubMed]

23. Wang, H.; Hou, L.; Liu, Y.; Liu, K.; Zhang, L.; Huang, F.; Wang, L.; Rashid, A.; Hu, A.; Yu, C. Horizontal and ver-tical gene transfer drive sediment antibiotic resistome in an urban lagoon system. J. Environ. Sci. 2021, 102, 11-23. [CrossRef]

24. Chen, Q.-L.; Cui, H.-L.; Su, J.-Q.; Penuelas, J.; Zhu, Y.-G. Antibiotic Resistomes in Plant Microbiomes. Trends Plant Sci. 2019, 24, 530-541. [CrossRef] [PubMed]

25. Zhang, L.; Kinkelaar, D.; Huang, Y.; Li, Y.; Li, X.; Wang, H.H. Acquired Antibiotic Resistance: Are We Born with It? Appl. Environ. Microbiol. 2011, 77, 7134-7141. [CrossRef] [PubMed] 
26. Verraes, C.; VanBoxstael, S.; Van Meervenne, E.; Van Coillie, E.; Butaye, P.; Catry, B.; De Schaetzen, M.-A.; Van Huffel, X.; Imberechts, H.; Dierick, K.; et al. Antimicro-bial Resistance in the Food Chain: A Review. Int. J. Environ. Res. Public Health 2013, 10, 2643-2669. [CrossRef]

27. Su, J.-Q.; Wei, B.; Ou-Yang, W.-Y.; Huang, F.-Y.; Zhao, Y.; Xu, H.-J.; Zhu, Y.-G. Antibiotic Resistome and Its As-sociation with Bacterial Communities during Sewage Sludge Composting. Environ. Sci. Technol. 2015, 49, 7356-7363. [CrossRef]

28. Zhou, X.; Qiao, M.; Wang, F.H.; Zhu, Y.G. Use of commercial organic fertilizer increases the abundance of an-tibiotic resistance genes and antibiotics in soil. Environ. Sci. Pollut. Res. Int. 2017, 24, 701-710. [CrossRef] [PubMed]

29. Lin, H.; Chapman, S.J.; Freitag, T.E.; Kyle, C.; Ma, J.; Yang, Y.; Zhang, Z. Fate of tetracycline and sulfonamide resistance genes in a grassland soil amended with different organic fertilizers. Ecotoxicol. Environ. Saf. 2019, 170, 39-46. [CrossRef]

30. Kumar, K.; Gupta, S.C.; Baidoo, S.K.; Chander, Y.; Rosen, C.J. Antibiotic Uptake by Plants from Soil Fertilized with Animal Manure. J. Environ. Qual. 2005, 34, 2082-2085. [CrossRef]

31. Sarmiento, M.R.A.; de Paula, T.O.; Borges, F.M.; Ferreira-Machado, A.B.; Resende, J.A.; Moreira, A.P.B.; Du-tra Luquetti, S.C.P.; Cesar, D.E.; da Silva, V.L.; Diniz, C.G. Obesity, Xenobiotic Intake and Antimicrobi-al-Resistance Genes in the Human Gastrointestinal Tract: A Comparative Study of Eutrophic, Overweight and Obese Individuals. Genes 2019, 10, 349. [CrossRef]

32. Sánchez-Osuna, M.; Cortés, P.; Barbé, J.; Erill, I. Origin of the Mobile Di-Hydro-Pteroate Synthase Gene Deter-mining Sulfonamide Resistance in Clinical Isolates. Front. Microbiol. 2019, 9, 3332. [CrossRef] [PubMed]

33. de Souza, M.M.S.; Coelho, S.D.M.; Coelho, I.D.S.; Soares, B.D.S.; da Motta, C.C.; de Melo, D.A.; Dubenczuk, F.C.; Santiago, G.S.; Pimenta, R.L.; Marques, V.F.; et al. Antimicrobial Resistance in Animal Production: An Overview. Braz. J. Vet. Med. 2016, 38, 68-74.

34. Koike, S.; Mackie, R.; Aminov, R.; Mirete, S.; Pérez, M.L. Agricultural use of antibiotics and antibiotic re-sistance. Antibiot. Resist. Genes Nat. Environ. Long Term Eff. 2017, 217-250.

35. Marosevic, D.; Kaevska, M.; Jaglic, Z. Resistance to the tetracyclines and macrolide-lincosamide-streptogramin group of antibiotics and its genetic linkage-A review. Ann. Agric. Environ. Med. 2017, 24, 338-344. [CrossRef]

36. Niestępski, S.; Harnisz, M.; Korzeniewska, E.; Aguilera-Arreola, M.G.; Contreras-Rodríguez, A.; Filipkowska, Z.; Osińska, A. The emergence of antimicrobial resistance in environmental strains of the Bacteroides fragilis group. Environ. Int. 2019, 124, 408-419. [CrossRef] [PubMed]

37. Sarkar, A.; Pazhani, G.P.; Dharanidharan, R.; Ghosh, A.; Ramamurthy, T. Detection of integron-associated gene cassettes and other antimicrobial resistance genes in enterotoxigenic Bacteroides fragilis. Anaerobe 2015, 33, 18-24. [CrossRef]

38. Santiago-Rodriguez, T.M.; Fornaciari, G.; Luciani, S.; Toranzos, G.A.; Marota, I.; Giuffra, V.; Sangwan, N.; Cano, R.J. Tetracyclinelike resistome of ancient human guts. Hum. Microbiome J. 2018, 10, 21-26. [CrossRef]

39. Santiago-Rodriguez, T.M.; Fornaciari, G.; Luciani, S.; Dowd, S.E.; Toranzos, G.A.; Marota, I.; Cano, R.J. Gut Microbiome of an 11th Century A.D. Pre-Columbian Andean Mummy. PLoS ONE 2015, 10, e0138135. [CrossRef]

40. Feng, J.; Li, B.; Jiang, X.; Yang, Y.; Wells, G.F.; Zhang, T.; Li, X. Antibiotic resistome in a large-scale healthy hu-man gut microbiota deciphered by metagenomic and network analyses. Environ. Microbiol. 2018, 20, 355-368. [CrossRef]

41. Hu, Y.; Yang, X.; Qin, J.; Lu, N.; Cheng, G.; Wu, N.; Pan, Y.; Li, J.; Zhu, L.; Wang, X.; et al. Meta-genome-wide analysis of antibiotic resistance genes in a large cohort of human gut microbiota. Nat. Commun. 2013, 4, 2151. [CrossRef]

42. Roberts, M. Environmental Macrolide-Lincosamide-Streptogramin and Tetracycline Resistant Bacteria. Front. Microbiol. 2011, 2, 40. [CrossRef] [PubMed]

43. Feßler, A.T.; Wang, Y.; Wu, C.; Schwarz, S. Mobile macrolide resistance genes in staphylococci. Plasmid 2018, 99, 2-10. [CrossRef] [PubMed]

44. Tekiner, S.H.; Özpinar, H. Occurrence and characteristics of extended spectrum beta-lactamases-producing Enterobacteriaceae from foods of animal origin. Braz. J. Microbiol. 2016, 47, 444-451. [CrossRef] [PubMed]

45. De Paula, A.C.L.; Medeiros, J.D.; De Azevedo, A.C.; De Assis Chagas, J.M.; Da Silva, V.L.; Diniz, C.G. Antibiotic Resistance Genetic Markers and Integrons in White Soft Cheese: Aspects of Clinical Resistome and Potentiality of Horizontal Gene Transfer. Genes 2018, 9, 106. [CrossRef]

46. Zieliński, W.; Buta, M.; Hubeny, J.; Korzeniewska, E.; Harnisz, M.; Nowrotek, M.; Płaza, G. Prevalence of Beta Lactamases Genes in Sewage and Sludge Treated in Mechanical-Biological Wastewater Treatment Plants. J. Ecol. Eng. 2019, 20, 80-86. [CrossRef]

47. van den Bunt, G.; van Pelt, W.; Hidalgo, L.; Scharringa, J.; de Greeff, S.C.; Schürch, A.C.; Mughini-Gras, L.; Bonten, M.J.M.; Fluit, A.C. Prevalence, Risk Factors and Genetic Characterisation of Extended-Spectrum Beta-Lactamase and CarbapenemaseProducing Enterobacteriaceae (ESBL-E and CPE): A community-Based Cross-Sectional Study, The Netherlands. Eurosurveillance 2019, 24, 1800594. [CrossRef] [PubMed]

48. Iseppi, R.; Di Cerbo, A.; Messi, P.; Sabia, C. Antibiotic Resistance and Virulence Traits in Vancomy-cin-Resistant Enterococci (VRE) and Extended-Spectrum $\beta$-Lactamase/AmpC-producing (ESBL/AmpC) Enter-obacteriaceae from Humans and Pets. Antibiotics 2020, 9, 152. [CrossRef] [PubMed]

49. Schill, F.; Abdulmawjood, A.; Klein, G.; Reich, F. Prevalence and characterization of extended-spectrum $\beta$-lactamase (ESBL) and AmpC $\beta$-lactamase producing Enterobacteriaceae in fresh pork meat at processing level in Germany. Int. J. Food Microbiol. 2017, 257, 58-66. [CrossRef] [PubMed]

50. Bengtsson-Palme, J.; Angelin, M.; Huss, M.; Kjellqvist, S.; Kristiansson, E.; Palmgren, H.; Larsson, D.G.J.; Johansson, A. The Human Gut Microbiome as a Transporter of Antibiotic Resistance Genes between Con-tinents. Antimicrob. Agents Chemother. 2015, 59, 6551-6560. [CrossRef] [PubMed] 
51. Adesoji, A.T.; Ogunjobi, A.A.; Olatoye, I.O. Characterization of Integrons and Sulfonamide Resistance Genes among Bacteria from Drinking Water Distribution Systems in Southwestern Nigeria. Chemotherapy 2016, 62, 34-42. [CrossRef]

52. Xiong, W.; Sun, Y.; Zhang, T.; Ding, X.; Zhenling, Z.; Wang, M.; Zeng, Z. Antibiotics, Antibiotic Resistance Genes, and Bacterial Community Composition in Fresh Water Aquaculture Environment in China. Microb. Ecol. 2015, 70, 425-432. [CrossRef]

53. Mu, Q.; Li, J.; Sun, Y.; Mao, D.; Wang, Q.; Luo, Y. Occurrence of sulfonamide-, tetracycline-, plasmid-mediated quinolone- and macrolide-resistance genes in livestock feedlots in Northern China. Environ. Sci. Pollut. Res. 2015, 22, 6932-6940. [CrossRef]

54. Emachado, E.; Coque, T.M.; Cantón, R.; Sousa, J.C.; Peixe, L. Commensal Enterobacteriaceae as reservoirs of extended-spectrum beta-lactamases, integrons, and sul genes in Portugal. Front. Microbiol. 2013, 4, 80. [CrossRef]

55. Caruso, G.; Giammanco, A.; Cardamone, C.; Oliveri, G.; Mascarella, C.; Capra, G.; Fasciana, T. Extra-Intestinal FluoroquinoloneResistant Escherichia coli Strains Isolated from Meat. BioMed Res. Int. 2018, 2018, 8714975. [CrossRef]

56. Chenia, H.Y. Prevalence and characterization of plasmid-mediated quinolone resistance genes in Aeromonas spp. isolated from South African freshwater fish. Int. J. Food Microbiol. 2016, 231, 26-32. [CrossRef]

57. Von Wintersdorff, C.J.H.; Penders, J.; Van Niekerk, J.M.; Mills, N.D.; Majumder, S.; Van Alphen, L.B.; Savelkoul, P.H.M.; Wolffs, P.F.G. Dissemination of Antimicrobial Resistance in Microbial Ecosystems through Horizontal Gene Transfer. Front. Microbiol. 2016, 7, 173. [CrossRef]

58. Pham, T.D.M.; Ziora, Z.M.; Blaskovich, M.A.T. Quinolone antibiotics. MedChemComm 2019, 10, 1719-1739. [CrossRef] [PubMed]

59. Fitzpatrick, D.; Walsh, F. Antibiotic resistance genes across a wide variety of metagenomes. FEMS Microbiol. Ecol. 2016, 92, fiv168. [CrossRef]

60. Cambray, G.; Guerout, A.-M.; Mazel, D. Integrons. Annu. Rev. Genet. 2010, 44, 141-166. [CrossRef]

61. WHO. Obesity: Preventing and Managing the Global Epidemic; Report of a World Health Organization Consultation; World Health Organization: Geneva, Switzerland, 2000.

62. Cardoso, M.A.; Stocco, P.R. Development of a dietary assessment method for people of Japanese descent living in São Paulo. Brazil. Cad. Saude Publica 2000, 16, 107-114. [CrossRef]

63. Sales, R.L.; Silva, M.M.S.; Costa, N.M.B.; Euclydes, M.P.; Eckhardt, V.F.; Rodrigues, C.M.A.; Tinoco, A.L.A. Development of a questionnaire to assess food intake of population groups. Rev. Nutr. 2006, 19, 539-552. [CrossRef] 


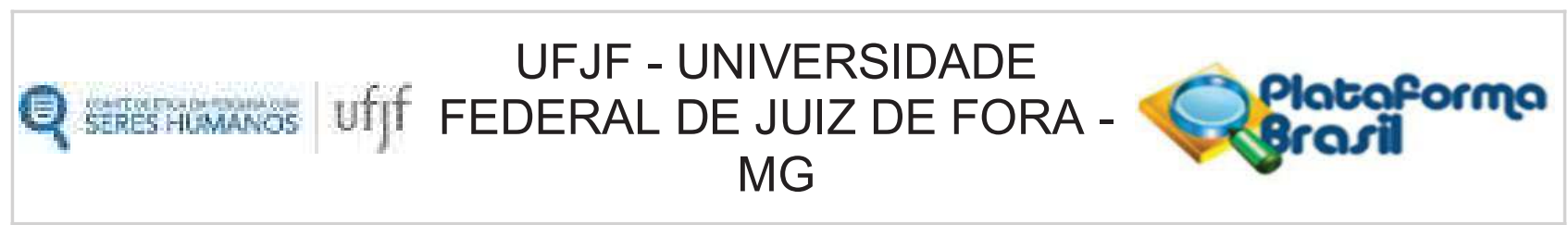

ANEXO B

\section{PARECER CONSUBSTANCIADO DO CEP}

\section{DADOS DO PROJETO DE PESQUISA}

Título da Pesquisa: Correlação entre dieta e microbiota: diversidade microbiana intestinal em indivíduos com diferentes hábitos alimentares

Pesquisador: Cláudio Galuppo Diniz

Área Temática:

Versão: 2

CAAE: 65841617.5 .0000 .5147

Instituição Proponente: Departamento de Parasitologia, Microbiologia e Imunologia/UFJF

Patrocinador Principal: Financiamento Próprio

\section{DADOS DO PARECER}

Número do Parecer: 2.046.122

\section{Apresentação do Projeto:}

Este será um estudo transversal onde serão convidados adultos saudáveis não obesos com diferentes hábitos alimentares baseados em diferentes tipos de dieta (veganismo, vegetarianismo, ovo-lactovegetarianismo e onivorismo). Os participantes serão recrutados na comunidade de Juiz de Fora, MG, após contato prévio com grupos de interesse e afinidade, utilizando-se as redes sociais. Apresentação do projeto esta clara, detalhada de forma objetiva, descreve as bases científicas que justificam o estudo, de acordo com as atribuições definidas na Resolução CNS 466/12 de 2012, item III.

\section{Objetivo da Pesquisa:}

Avaliar características sócio-demográficas, antropométricas, nutricionais e a diversidade bacteriana, seu perfil funcional e metabólico na microbiota intestinal de indivíduos com diferentes hábitos alimentares (veganismo, vegetarianismo, ovo-lacto-vegetarianismo e onivorismo). O Objetivo da pesquisa está bem delineado, apresenta clareza e compatibilidade com a proposta, tendo adequação da metodologia aos objetivos pretendido, de acordo com as atribuições definidas na Norma Operacional CNS 001 de 2013, item 3.4.1 - 4 .

Avaliação dos Riscos e Benefícios:

O estudo é classificado como de risco mínimo, isto é, o procedimento não acarretará riscos para

Endereço: JOSE LOURENCO KELMER S/N

Bairro: SAO PEDRO

UF: MG Município: JUIZ DE FORA

Telefone: (32)2102-3788 Fax: (32)1102-3788 E-mail: cep.propesq@ufjf.edu.br 


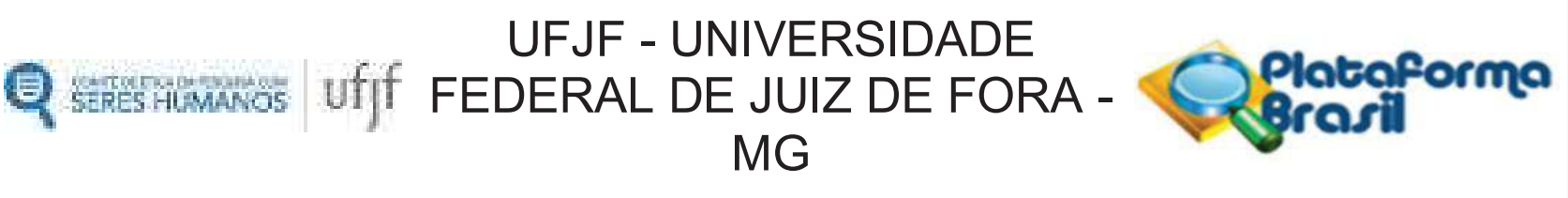

Continuação do Parecer: 2.046.122

os participantes, maiores do que aqueles aos quais eles estariam expostos na sua rotina do dia-a-dia. Eventuais desconfortos físicos ou emocionais serão minimizados, uma vez que os dados antropométricos e demais informações serão obtidas durante consulta individual no domicilio do participante, com nutricionista experiente ou acadêmico de nutrição e o espécime clínico fecal será coletado no domicílio do participante. Acredita-se que este projeto possa contribuir, de maneira geral, para dimensionar a distribuição diferencial bacteriana na microbiota residente intestinal de indivíduos com diferentes hábitos alimentares, seu papel no ecossistema pela determinação dos perfis funcionais e metabólicos. Esses conhecimentos, de caráter regional, poderiam contribuir para suscitar discussões sobre o envolvimento destas variáveis na etiologia multifatorial de doenças associadas ao desequilíbrio da microbiota residente intestinal e suas comorbidades. Além disso, os resultados deste projeto podem gerar indicadores que poderiam ser usados para predizer condições de saúde através do levantamento dos dados de alterações fisiológicas e moleculares relacionadas à fisiologia microbiana no ecossistema intestinal e resposta do hospedeiro a esses microrganismos, correlações entre fatores do

comportamento que possam modular estas variáveis, como perfil nutricional; ainda, possibilitar a consolidação da equipe multidisciplinar envolvida no estudo. Identificação dos riscos e as possibilidades de desconfortos e benefícios esperados, estão adequadamente descritos. A avaliação dos Riscos e Benefícios estão de acordo com as atribuições definidas na Resolução CNS 466/12 de 2012, itens III; III.2 e V.

\section{Comentários e Considerações sobre a Pesquisa:}

O projeto está bem estruturado, delineado e fundamentado, sustenta os objetivos do estudo em sua metodologia de forma clara e objetiva, e se apresenta em consonância com os princípios éticos norteadores da ética na pesquisa científica envolvendo seres humanos elencados na resolução 466/12 do CNS e com a Norma Operacional No 001/2013 CNS.

\section{Considerações sobre os Termos de apresentação obrigatória:}

O protocolo de pesquisa está em configuração adequada, apresenta FOLHA DE ROSTO devidamente preenchida,com o título em português, identifica o patrocinador pela pesquisa, estando de acordo com as atribuições definidas na Norma Operacional CNS 001 de 2013 item 3.3 letra a; e 3.4.1 item 16. Apresenta o TERMO DE CONSENTIMENTO LIVRE ESCLARECIDO em linguagem clara para compreensão dos participantes, apresenta justificativa e objetivo, campo para identificação do participante, descreve de forma suficiente os procedimentos, informa que uma das vias do TCLE será entregue aos participantes,assegura a liberdade do participante recusar ou retirar o consentimento sem penalidades,garante sigilo e anonimato, explicita riscos e

Endereço: JOSE LOURENCO KELMER S/N

Bairro: SAO PEDRO

UF: MG Município: JUIZ DE FORA

Telefone: (32)2102-3788 Fax: (32)1102-3788 E-mail: cep.propesq@ufjf.edu.br 


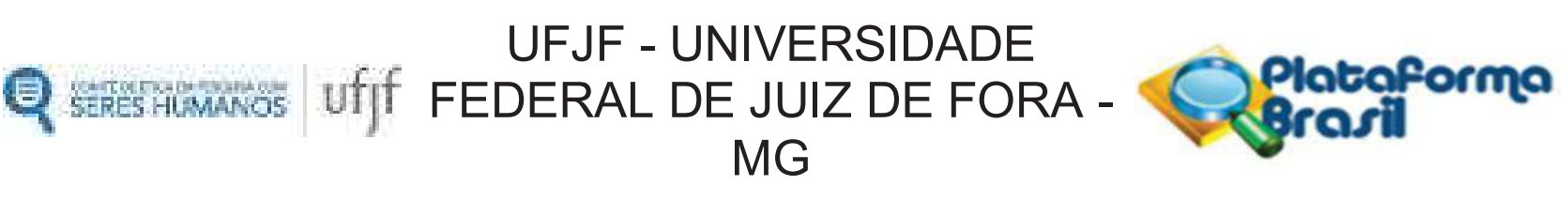

Continuação do Parecer: 2.046.122

desconfortos esperados, indenização diante de eventuais danos decorrentes da pesquisa,contato do pesquisador e do CEP e informa que os dados da pesquisa ficarão arquivados com o pesquisador pelo período de cinco anos, de acordo com as atribuições definidas na Resolução CNS 466 de 2012, itens:IV letra b; IV.3 letras a,b,d,e,f,g e h; IV. 5 letra d e XI.2 letra f. Apresenta o INSTRUMENTO DE COLETA DE DADOS de forma pertinente aos objetivos delineados e preserva os participantes da pesquisa. $O$ Pesquisador apresenta titulação e experiência compatível com o projeto de pesquisa, estando de acordo com as atribuições definidas no Manual Operacional para CPEs. Apresenta DECLARAÇÃO de infraestrutura e de concordância com a realização da pesquisa de acordo com as atribuições definidas na Norma Operacional CNS 001 de 2013 item 3.3 letra h.

\section{Conclusões ou Pendências e Lista de Inadequações:}

Diante do exposto, o projeto está aprovado, pois está de acordo com os princípios éticos norteadores da ética em pesquisa estabelecido nas Resoluções CNS 466/12; 441/12; com a Norma Operacional $\mathrm{N}^{\circ}$ 001/2013 CNS e com a Portaria 2.201/12. Data prevista para o término da pesquisa: Outubro de 2020.

\section{Considerações Finais a critério do CEP:}

Diante do exposto, o Comitê de Ética em Pesquisa CEP/UFJF, de acordo com as atribuições definidas nas Resoluções CNS 466/12; 441/12; com a Norma Operacional № 001/2013 CNS e com a Portaria 2.201/12, manifesta-se pela APROVAÇÃO do protocolo de pesquisa proposto. Vale lembrar ao pesquisador responsável pelo projeto, o compromisso de envio ao CEP de relatórios parciais e/ou total de sua pesquisa informando o andamento da mesma, comunicando também eventos adversos e eventuais modificações no protocolo.

Este parecer foi elaborado baseado nos documentos abaixo relacionados:

\begin{tabular}{|l|l|c|l|c|}
\hline \multicolumn{1}{|c|}{ Tipo Documento } & \multicolumn{1}{|c|}{ Arquivo } & Postagem & Autor & Situação \\
\hline Informações Básicas & PB_INFORMAÇOES_BASICAS_DO_P & $03 / 05 / 2017$ & & Aceito \\
do Projeto & ROJETO_882807.pdf & $16: 31: 31$ & \\
\hline Projeto Detalhado / & Projeto_Modelo_CEP_2017_plataforma & $03 / 05 / 2017$ \\
Brochura & Cláudio Galuppo & Aceito \\
Investigador & Brasil.doc & & \\
\hline Declaração de & declaracao_para_biorrepositorio.pdf & $16 / 03 / 2017$ & Cláudio Galuppo & Aceito \\
\hline
\end{tabular}

Endereço: JOSE LOURENCO KELMER S/N

Bairro: SAO PEDRO

UF: MG

Município: JUIZ DE FORA

Telefone: (32)2102-3788

Fax: (32)1102-3788 E-mail: cep.propesq@ufjf.edu.br

CEP: $\quad 36.036-900$ 


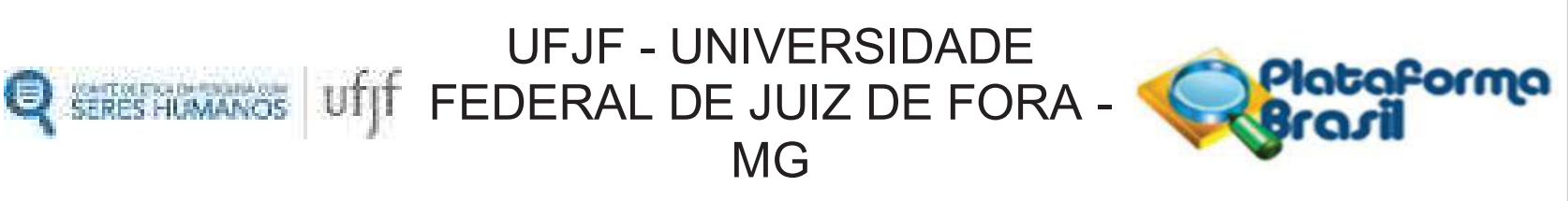

Continuação do Parecer: 2.046.122

\begin{tabular}{|l|l|c|l|c|}
\hline $\begin{array}{l}\text { Instituição e } \\
\text { Infraestrutura }\end{array}$ & declaracao_para_biorrepositorio.pdf & $21: 52: 05$ & Diniz & Aceito \\
\hline Declaração de & declaracao_infraestrutura.pdf & $16 / 03 / 2017$ & $\begin{array}{l}\text { Cláudio Galuppo } \\
\text { Diniz }\end{array}$ & Aceito \\
Instituição e & & $16: 55: 29$ & \\
\hline Infraestrutura & & $16 / 03 / 2017$ & Cláudio Galuppo \\
TCLE / Termos de & TCLE_Biorrepositorio.doc & $16: 54: 59$ & Diniz & Aceito \\
Jussentimento / & & & & Aceito \\
Ausência & & $16 / 03 / 2017$ & Cláudio Galuppo \\
\hline TCLE / Termos de & TCLE.doc & $16: 52: 35$ & Diniz & \\
Assentimento / & & & & Aceito \\
Justificativa de & & $16 / 03 / 2017$ & Cláudio Galuppo \\
Ausência & & $16: 46: 49$ & Diniz \\
\hline Outros & Intrumentos.doc & $16: 41: 26$ & Cláudio Galuppo & Aceito \\
\hline Folha de Rosto & folha_de_rosto.pdf & & \\
\hline
\end{tabular}

\section{Situação do Parecer:}

Aprovado

Necessita Apreciação da CONEP:

Não

JUIZ DE FORA, 04 de Maio de 2017

\section{Assinado por:}

Lainer Augusta da Cunha Serrano

(Coordenador)

Endereço: JOSE LOURENCO KELMER S/N

Bairro: SAO PEDRO

UF: MG

Município: JUIZ DE FORA

Telefone: (32)2102-3788

Fax: (32)1102-3788

CEP: $\quad 36.036-900$

Telefone: (32)2102-3788 Fax: (32)1102-3788 E-mail: cep.propesq@ufj.edu.br




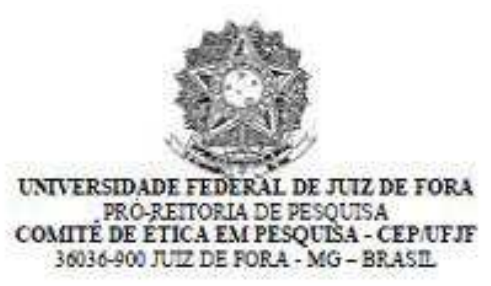

\section{ANEXO C - TERMO DE CONSENTIMENTO LIVRE E ESCLARECIDO}

O Sr. (a) está sendo convidado (a) como voluntário(a) a participar da pesquisa "CORRELAÇÃO ENTRE DIETA E MICROBIOTA: DIVERSIDADE MICROBIANA INTESTINAL EM INDIVIDUUOS COM DIFERENTES HÁBITOS ALIMENTARES".

Nesta pesquisa pretendemos avaliar a diversidade bacteriana, seu perfil funcional e metabólico, e parâmetros imunológicos de indivíduos que seguem dieta onívora, ovolactovegetariana ou vegana.

Estudos revelam que hábitos alimentares saudáveis podem contribuir para modular, de modo benéfico, as reações entre a microbiota entérica e o hospedeiro, estabelecendo um caminho efetivo na prevenção de várias doenças, tais como doenças cardiovasculares, gastrointestinais, neurológicas e endócrinas.

Acredita-se que esta pesquisa possa contribuir para dimensionar a distribuição bacteriana na microbiota residente intestinal de indivíduos com diferentes hábitos alimentares, seu papel no ecossistema pela determinação dos perfis funcionais e metabólicos, e aspectos da resposta imunológica sistêmica nestes indivíduos.

Para este estudo estão sendo convidados adultos com dieta alimentar onívora, ovolactovegetariana ou vegana, seguida por no mínimo um ano. Os fatores de exclusão do estudo incluem gestação, lactação, diabetes, hipertensão, doença cardíaca, idade inferior a 18 anos, idade superior a 65 anos e obesidade, dieta alimentar seguida há menos de um ano, doenças renais e/ou outras doenças crônicas. Os participantes responderão a um questionário de dados clínicos, epidemiológicos, um formulário para avaliação do estilo de vida e serão submetidos à avaliação antropométrica (peso, altura, Índice de Massa Corporal, circunferência da cintura, circunferência abdominal e percentual de gordura corporal), avaliação nutricional (pela informação da frequência alimentar media do consumo habitual relativa aos últimos seis meses) e coleta de espécimes clínicos (fezes).

- Considerando-se os riscos envolvendo pesquisas com seres humanos, de acordo com o preconizado pela legislação vigente (resolução 466/12 do Conselho Nacional de Saúde), o estudo é classificado como de risco mínimo, isto é, o procedimento não acarretará riscos para os participantes, maiores do que aqueles aos quais eles estariam expostos na sua rotina.

- Eventuais desconfortos físicos ou emocionais serão minimizados, uma vez que os dados antropométricos serão obtidos em sala adequada e os espécimes clínicos serão coletados em domicílio (fezes no coletor fornecido), de acordo com um guia de coleta de fezes fornecido pelo pesquisador e sua equipe.

- Para participar deste estudo o $\operatorname{Sr}(a)$ não terá nenhum custo, nem receberá qualquer vantagem financeira. Terá o esclarecimento sobre o estudo em qualquer aspecto que desejar e estará livre para participar ou recusar-se a participar. Poderá retirar seu consentimento ou interromper a participação a qualquer momento. A sua participação é voluntária e a recusa em participar não acarretará qualquer penalidade ou modificação na forma em que é atendido pelo pesquisador, que tratará a sua identidade com padrões profissionais de sigilo. 
- Os resultados da pesquisa estarão à sua disposição quando finalizada. Seu nome ou o material que indique sua participação não será liberado sem a sua permissão e o(a) $\operatorname{Sr}(a)$ não será identificado em nenhuma publicação que possa resultar.

Este termo de consentimento encontra-se impresso em duas vias, sendo que uma cópia será arquivada pelo pesquisador responsável, no Instituto de Ciências Biológicas/UFJF, Setor de Microbiologia e a outra será fornecida ao senhor(a). Os dados e instrumentos utilizados na pesquisa ficarão arquivados com o pesquisador responsável por um período de 5(cinco) anos, e após esse tempo serão destruídos.

$\mathrm{Eu}$, portador do documento de Identidade fui informado (a) dos objetivos da pesquisa "CORRELAÇÃO ENTRE DIETA E MICROBIOTA: DIVERSIDADE MICROBIANA INTESTINAL EM INDIVÍDUOS COM DIFERENTES HÁBITOS ALIMENTARES", de maneira clara e detalhada e esclareci minhas dúvidas. Sei que a qualquer momento solicitar novas informações e modificar minha decisão de participar se assim o desejar.

Declaro que concordo em participar. Recebi uma cópia deste termo de consentimento livre e esclarecido e me foi dada à oportunidade de ler e esclarecer as minhas dúvidas.

Juiz de Fora, de de 20

$\begin{array}{lll}\text { Nome Assinatura participante Data } & \text { Da }\end{array}$

Em caso de dúvidas, com respeito aos aspectos éticos desta pesquisa, você poderá consultar:

CEP - COMITÊ DE ÉTICA EM PESQUISA/UFJF

CAMPUS UNIVERSITÁRIO DA UFJF

PRÓ-REITORIA DE PESQUISA

CEP: 36036-900

FONE: (32) 2102-3788/ E-MAIL: cep.propesq@ufjf.edu.br

PESQUISADOR RESPONSÁVEL: PROF. DR. CLÁUDIO GALUPPO DINIZ

DEPTP. PARASITOLOGIA, MICROBIOLOGIA E IMUNOLOGIA

ICB/UNIVERSIDADE FEDERAL DE JUIZ DE FORA

RUA LOURENÇO KELMER, S/N - CAMPUS UNIVERSITÁRIO

BAIRRO SÃO PEDRO - CEP: 36036-330 - JUIZ DE FORA, MG

E-MAIL: claudio.diniz@ufjf.edu.br 
ANEXO D - QUESTIONÁRIO QUANTITATIVO DE FREQUÊNCIA ALIMENTAR (QQFA) ADAPTADO

PROJETO DE PESQUISA: CORRELAÇÃO ENTRE DIETA E MICROBIOTA: DIVERSIDADE MICROBIANA INTESTINAL EM INDIVÍDUOS COM DIFERENTES HÁBITOS ALIMENTARES.

\section{FORMULÁRIO PARA COLETA DE DADOS CLÍNICO-EPIDEMIOLÓGICOS}

Participante $\mathrm{N}^{\circ}$ L_L__L Data:

Nome:

e-mail:
Idade (anos):

Telefones:

1. Estado civil: [ ] solteiro(a) [ ] casado(a) [ ] outro

2. Cor: [ ] branca [ ] preta [ ] parda [ ] amarela [ ] outra

3. Dieta: [ ] vegana [ ] ovo-lacto vegertariana [ ] onívora Tempo que segue esta dieta:

4. Você tem ou já teve algum acompanhamento profissional em relação à sua dieta: [ ] sim [ ] não Que tipo:

5. Utiliza alimentos orgânicos: [ ] $\operatorname{sim}[$ ] não Tempo que consome orgânicos:

6. Utiliza adoçantes: [ ] sim [ ] não Tempo que usa: Usa qual(is) principalmente:

7. Nível de escolaridade:

8. Ocupação profissional:

9. Vida sexual ativa: [ ] não [ ] sim - Parceiros [ ] 01 [ ] mais de 01

10. Renda familiar? [ ] 1 a 3 salários [ ] 4 a 6 salários [ ] 7 a 9 salários [ ] acima de 10 salários mínimos

Número de pessoas que vivem desta renda:

11. Antibióticos nos últimos 30 dias:

Antifúngico [ ] $\operatorname{sim}[$ ] não Antibacteriano [ ] $\operatorname{sim}[$ ] não Antiprotozoário [ ] sim [ ]não

12. Medicamentos suplementares:

Insulina: [ ] $\operatorname{sim}[$ ] não

Hipoglicemiante oral: [ ] $\operatorname{sim}$ [ ] não

Anti-hipertensivo: [ ] sim [ ] não

Antidepressivo: [ ] $\operatorname{sim}[$ ] não

Dislipidêmicos: [ ] sim [ ] não

Outros:

13. Utiliza suplementos alimentares (polivitamínicos, ferro, B12, D, C): [ ] sim [ ] não Descrever:

14. Utiliza probióticos e/ou prebióticos: [ ] sim [ ] não

Descrever: 
15. Apresenta alguma patologia:

Diabetes: [ ] sim [ ] não [ ] não sabe

Hipertensão: [ ] sim [ ] não [ ] não sabe

Doenças hepáticas: [ ] sim [ ] não [ ] não sabe

Doenças na tireóide: [ ] sim [ ] não [ ] não sabe

Doenças cardíacas: [ ] sim [ ] não [ ] não sabe Doenças renais: [ ] sim [ ] não [ ] não sabe Depressão: [ ] sim [ ] não [ ] não sabe Soropositivo(a) para HIV: [ ] sim [ ] não [ ] não sabe Imunossupressão: [ ] sim [ ] não [ ] não sabe Outra(s): 
PROJETO DE PESQUISA: CORRELAÇÃO ENTRE DIETA E MICROBIOTA: DIVERSIDADE MICROBIANA INTESTINAL EM INDIVÍDUOS COM DIFERENTES HÁBITOS ALIMENTARES.

\section{QUESTIONÁRIO QUANTITATIVO DE FREQUÊNCIA ALIMENTAR}

Nome:

Idade (anos):

Participante $\mathrm{N}^{\circ}$

Prezado participante, informe a frequência média de consumo habitual (diária, semanal ou mensal) relativa aos últimos seis meses e o tamanho da porção ingerida. Para ajudá-lo na estimativa das porções há um álbum fotográfico elaborado por VANNUCCHI et al., 2007.

ATENÇÃO: Não altere sua rotina alimentar! A autenticidade da sua informação é fundamental. Seus registros serão mantidos em sigilo!

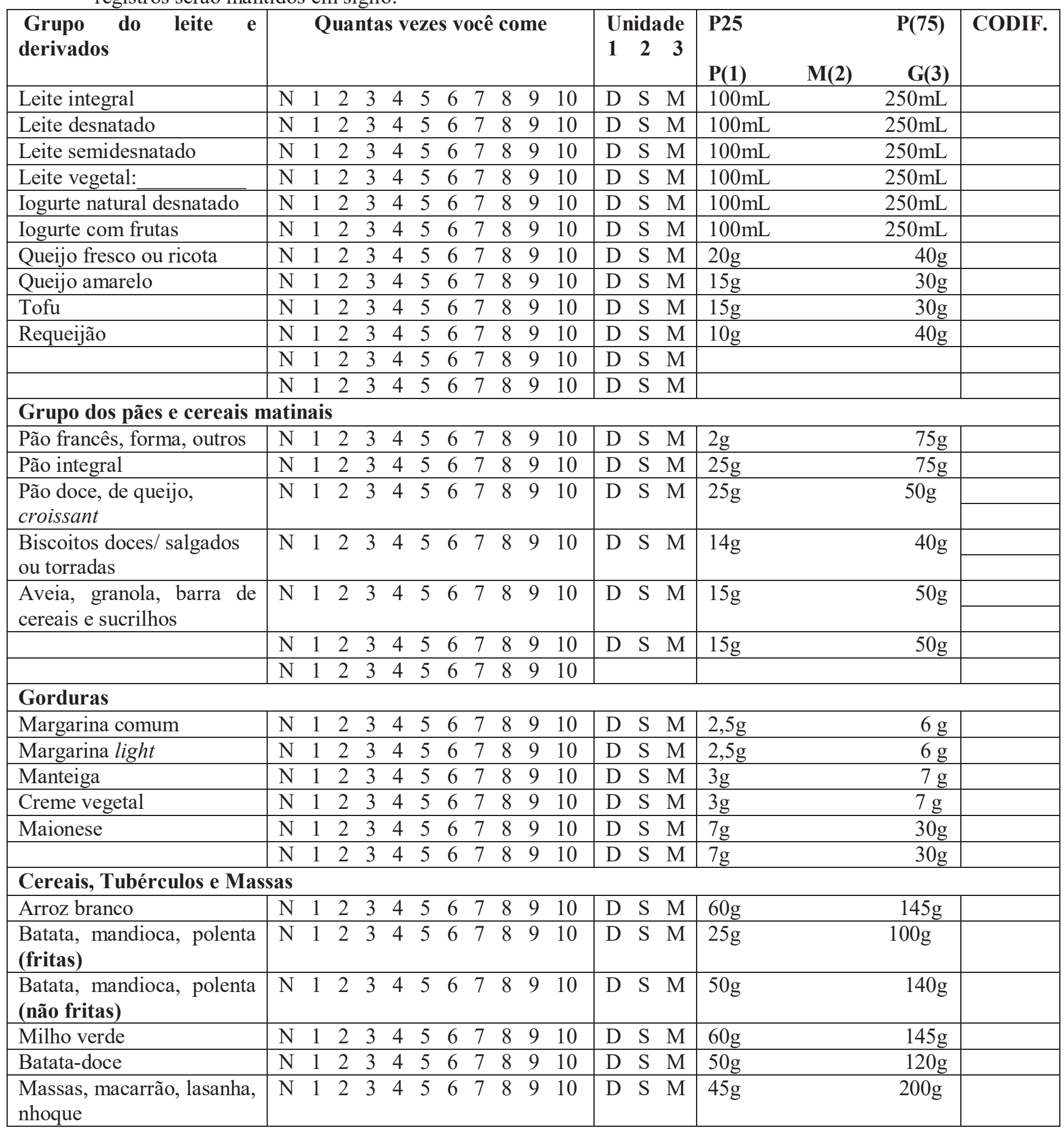




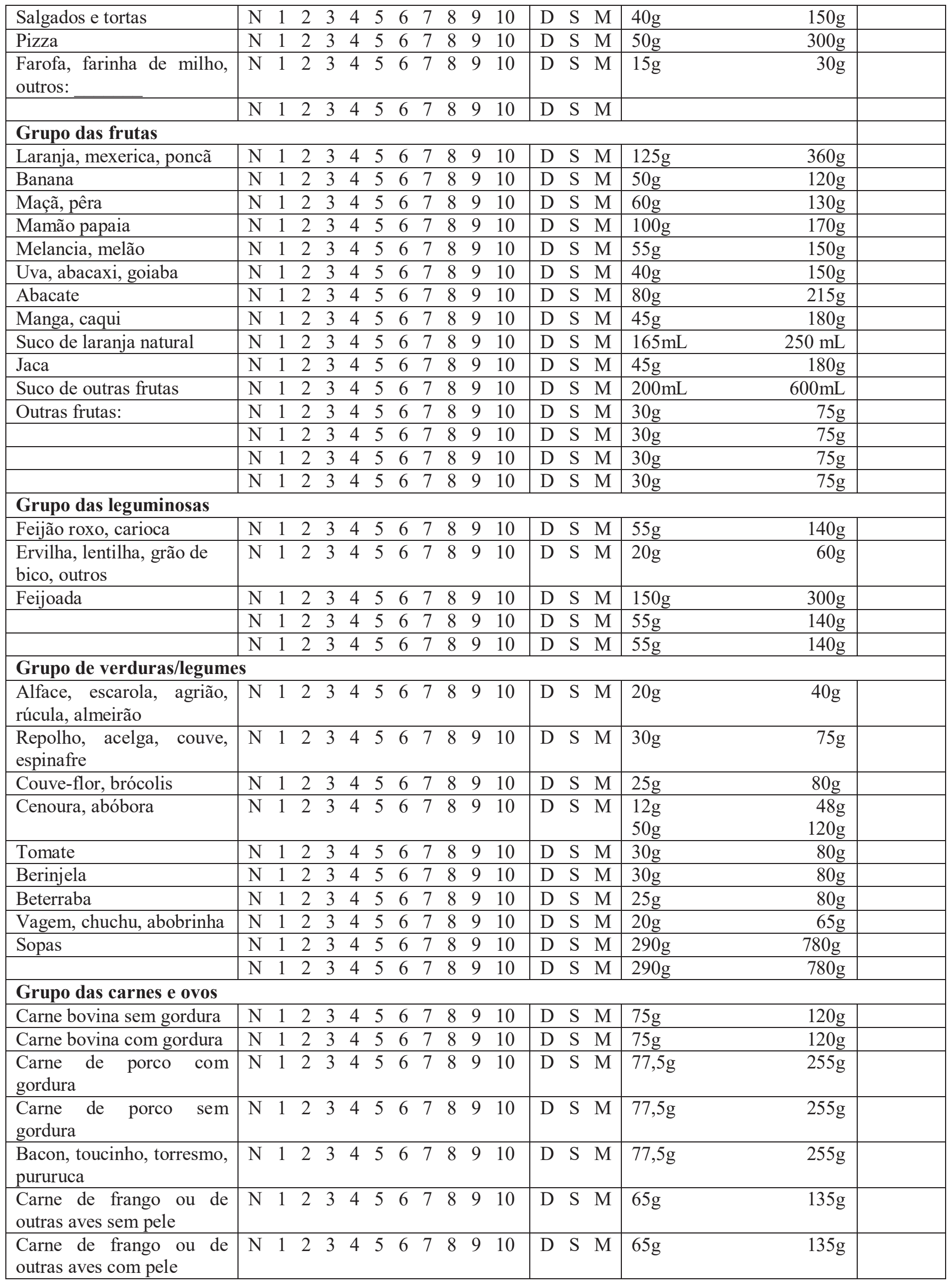




\begin{tabular}{|c|c|c|c|c|c|c|c|c|c|c|c|c|c|c|}
\hline Peixes & $\mathrm{N} 1$ & 2 & 3 & 4 & 5 & 6 & 78 & 8 & 9 & 10 & $\mathrm{D} \quad \mathrm{S} \quad \mathrm{M}$ & $100 \mathrm{~g}$ & $230 \mathrm{~g}$ & \\
\hline $\begin{array}{l}\text { Miúdos, dobradinha, } \\
\text { fígado, coração }\end{array}$ & N 1 & 2 & 3 & 4 & 5 & 6 & 7 & 8 & 9 & 10 & $\mathrm{D} \quad \mathrm{S} \quad \mathrm{M}$ & $6 \mathrm{~g}$ & $130 \mathrm{~g}$ & \\
\hline Camarão, frutos-do-mar & $\mathrm{N} 1$ & 2 & 3 & 4 & 5 & 6 & 7 & 8 & 9 & 10 & $\mathrm{D} \quad \mathrm{S} \quad \mathrm{M}$ & $50 \mathrm{~g}$ & $150 \mathrm{~g}$ & \\
\hline Linguiça, salsicha & $\mathrm{N} 1$ & 2 & 3 & 4 & 5 & 6 & 7 & 8 & 9 & 10 & $\begin{array}{|lll|}D & S & M \\
\end{array}$ & $40 \mathrm{~g}$ & $120 \mathrm{~g}$ & \\
\hline Ovo cozido & $\mathrm{N} 1$ & 2 & 3 & 4 & 5 & 6 & 7 & 8 & 9 & 10 & \begin{tabular}{lll|}
$\mathrm{D}$ & $\mathrm{S}$ & $\mathrm{M}$ \\
\end{tabular} & $25 \mathrm{~g}$ & $100 \mathrm{~g}$ & \\
\hline Ovo frito & $\mathrm{N} 1$ & 2 & 3 & 4 & 5 & 6 & 7 & 8 & 9 & 10 & \begin{tabular}{lll|}
$\mathrm{D}$ & $\mathrm{S}$ & $\mathrm{M}$ \\
\end{tabular} & $25 \mathrm{~g}$ & $100 \mathrm{~g}$ & \\
\hline Presunto, mortadela & $\mathrm{N} 1$ & 2 & 3 & 4 & 5 & 6 & 7 & 8 & 9 & 10 & $\mathrm{D} \quad \mathrm{S} \quad \mathrm{M}$ & $15 \mathrm{~g}$ & $30 \mathrm{~g}$ & \\
\hline \multicolumn{15}{|c|}{ Grupo das proteínas vegetais } \\
\hline $\begin{array}{l}\text { Proteína texturizada de } \\
\text { soja }\end{array}$ & N 1 & 2 & 3 & 4 & 5 & 6 & 7 & 8 & 9 & 10 & $\mathrm{D} \quad \mathrm{S} \quad \mathrm{M}$ & $75 \mathrm{~g}$ & $120 \mathrm{~g}$ & \\
\hline Presunto vegetal & $\mathrm{N} 1$ & 2 & 3 & 4 & 5 & 6 & 7 & 8 & 9 & 10 & $\begin{array}{|lll|}\mathrm{D} & \mathrm{S} & \mathrm{M} \\
\end{array}$ & $15 \mathrm{~g}$ & $30 \mathrm{~g}$ & \\
\hline Seitan & N 1 & 2 & 3 & 4 & 5 & 6 & 7 & 8 & 9 & 10 & $\begin{array}{|lll|} & S & M \\
\end{array}$ & $75 \mathrm{~g}$ & $120 \mathrm{~g}$ & \\
\hline \multirow[t]{3}{*}{ Cogumelos } & $\mathrm{N} 1$ & 2 & 3 & 4 & 5 & 6 & 7 & 8 & 9 & 10 & $\mathrm{D} \quad \mathrm{S} \quad \mathrm{M}$ & $75 \mathrm{~g}$ & $120 \mathrm{~g}$ & \\
\hline & $\mathrm{N} 1$ & 2 & 3 & 4 & 5 & 6 & 7 & 8 & 9 & 10 & $\mathrm{D} \quad \mathrm{S} \quad \mathrm{M}$ & $75 \mathrm{~g}$ & $120 \mathrm{~g}$ & \\
\hline & $\mathrm{N} 1$ & 2 & 3 & 4 & 5 & 6 & 7 & 8 & 9 & 10 & $\mathrm{D} \quad \mathrm{S} \quad \mathrm{M}$ & $75 \mathrm{~g}$ & $120 \mathrm{~g}$ & \\
\hline \multicolumn{15}{|l|}{ Grupo das bebidas } \\
\hline Café amargo & $\mathrm{N} 1$ & 2 & 3 & 4 & 5 & 6 & 7 & 8 & 9 & 10 & $\begin{array}{|lll|}\mathrm{D} & \mathrm{S} & \mathrm{M} \\
\end{array}$ & $50 \mathrm{~mL}$ & $100 \mathrm{~mL}$ & \\
\hline Café com açúcar & N 1 & 2 & 3 & 4 & 5 & 6 & 7 & 8 & 9 & 10 & $\begin{array}{|lll|} & S & M \\
\end{array}$ & $50 \mathrm{~mL}$ & $100 \mathrm{~mL}$ & \\
\hline Café com adoçante & $\mathrm{N} 1$ & 2 & 3 & 4 & 5 & 6 & 7 & 8 & 9 & 10 & $\mathrm{D} \quad \mathrm{S} \quad \mathrm{M}$ & $50 \mathrm{~mL}$ & $100 \mathrm{~mL}$ & \\
\hline Chá preto ou mate & $\mathrm{N} 1$ & 2 & 3 & 4 & 5 & 6 & 7 & 8 & 9 & 10 & $\begin{array}{|lll|} & \mathrm{S} & \mathrm{M} \\
\end{array}$ & $150 \mathrm{~mL}$ & $300 \mathrm{~mL}$ & \\
\hline Chá de ervas & $\mathrm{N} 1$ & 2 & 3 & 4 & 5 & 6 & 7 & 8 & 9 & 10 & D $\quad \mathrm{S} \quad \mathrm{M}$ & $150 \mathrm{~mL}$ & $300 \mathrm{~mL}$ & \\
\hline Água & $\mathrm{N} 1$ & 2 & 3 & 4 & 5 & 6 & 7 & 8 & 9 & 10 & $\mathrm{D} \quad \mathrm{S} \quad \mathrm{M}$ & $120 \mathrm{~mL}$ & $360 \mathrm{~mL}$ & \\
\hline Cerveja & $\mathrm{N} 1$ & 2 & 3 & 4 & 5 & 6 & 7 & 8 & 9 & 10 & $\mathrm{D} \quad \mathrm{S} \quad \mathrm{M}$ & $300 \mathrm{~mL}$ & $600 \mathrm{~mL}$ & \\
\hline Pinga, destilados & $\mathrm{N} 1$ & 2 & 3 & 4 & 5 & 6 & 7 & 8 & 9 & 10 & D S M & $45 \mathrm{~mL}$ & $90 \mathrm{~mL}$ & \\
\hline Vinho & $\mathrm{N} 1$ & 2 & 3 & 4 & 5 & 6 & 7 & 8 & 9 & 10 & D $\quad \mathrm{S} \quad \mathrm{M}$ & $60 \mathrm{~mL}$ & $200 \mathrm{~mL}$ & \\
\hline Sucos artificiais & N 1 & 2 & 3 & 4 & 5 & 6 & 7 & 8 & 9 & 10 & $\mathrm{D} \quad \mathrm{S} \quad \mathrm{M}$ & $200 \mathrm{~mL}$ & $600 \mathrm{~mL}$ & \\
\hline Refrigerante diet/light & $\mathrm{N} 1$ & 2 & 3 & 4 & 5 & 6 & 7 & 8 & 9 & 10 & $\mathrm{D} \quad \mathrm{S} \quad \mathrm{M}$ & $200 \mathrm{~mL}$ & $350 \mathrm{~mL}$ & \\
\hline \multirow[t]{4}{*}{ Refrigerante comum } & $\mathrm{N} 1$ & 2 & 3 & 4 & 5 & 6 & 7 & 8 & 9 & 10 & $\mathrm{D} \quad \mathrm{S} \quad \mathrm{M}$ & $200 \mathrm{~mL}$ & $350 \mathrm{~mL}$ & \\
\hline & $\mathrm{N} 1$ & 2 & 3 & 4 & 5 & 6 & 7 & 8 & 9 & 10 & $\mathrm{D} \quad \mathrm{S} \quad \mathrm{M}$ & $200 \mathrm{~mL}$ & $350 \mathrm{~mL}$ & \\
\hline & $\mathrm{N} 1$ & 2 & 3 & 4 & 5 & 6 & 7 & 8 & 9 & 10 & $\mathrm{D} \quad \mathrm{S} \quad \mathrm{M}$ & & & \\
\hline & $\mathrm{N} 1$ & 2 & 3 & 4 & 5 & 6 & 7 & 8 & 9 & 10 & D $\quad \mathrm{S} \quad \mathrm{M}$ & & & \\
\hline \multicolumn{15}{|c|}{ Grupo de doces e miscelâneas } \\
\hline Bolos, tortas, pavês & $\mathrm{N} 1$ & 2 & 3 & 4 & 5 & 6 & 7 & 8 & 9 & 10 & $\mathrm{D} \quad \mathrm{S} \quad \mathrm{M}$ & $50 \mathrm{~g}$ & $150 \mathrm{~g}$ & \\
\hline Chocolates, brigadeiro & $\mathrm{N} 1$ & 2 & 3 & 4 & 5 & 6 & 7 & 8 & 9 & 10 & $\mathrm{D} \quad \mathrm{S} \quad \mathrm{M}$ & $15 \mathrm{~g}$ & $50 \mathrm{~g}$ & \\
\hline Mel ou geléia & $\mathrm{N} 1$ & 2 & 3 & 4 & 5 & 6 & 7 & 8 & 9 & 10 & $\mathrm{D} \quad \mathrm{S} \quad \mathrm{M}$ & $9 \mathrm{~g}$ & $18 \mathrm{~g}$ & \\
\hline $\begin{array}{l}\text { Sorvetes, picolés, milk } \\
\text { shake }\end{array}$ & N 1 & 2 & 3 & 4 & 5 & 6 & 7 & 8 & 9 & 10 & $\mathrm{D} \quad \mathrm{S} \quad \mathrm{M}$ & $70 \mathrm{~g}$ & $160 \mathrm{~g}$ & \\
\hline Pudins, doces com leite & $\mathrm{N} 1$ & 2 & 3 & 4 & 5 & 6 & 7 & 8 & 9 & 10 & $\begin{array}{|lll|}\mathrm{D} & \mathrm{S} & \mathrm{M} \\
\end{array}$ & $50 \mathrm{~g}$ & $150 \mathrm{~g}$ & \\
\hline Doces de frutas & $\mathrm{N} 1$ & 2 & 3 & 4 & 5 & 6 & 7 & 8 & 9 & 10 & \begin{tabular}{lll|}
$\mathrm{D}$ & $\mathrm{S}$ & $\mathrm{M}$ \\
\end{tabular} & $20 \mathrm{~g}$ & $50 \mathrm{~g}$ & \\
\hline $\begin{array}{l}\text { Castanhas e oleaginosas, } \\
\text { amendoins }\end{array}$ & N 1 & 2 & 3 & 4 & 5 & 6 & 7 & 8 & 9 & 10 & 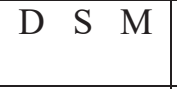 & $25 \mathrm{~g}$ & $100 \mathrm{~g}$ & \\
\hline Açaí & $\mathrm{N} 1$ & 2 & 3 & 4 & 5 & 6 & 7 & 8 & 9 & 10 & $\mathrm{D} \quad \mathrm{S} \quad \mathrm{M}$ & $200 \mathrm{~g}$ & $500 \mathrm{~g}$ & \\
\hline \multirow[t]{7}{*}{ Pipoca, chips, outros } & $\mathrm{N} 1$ & 2 & 3 & 4 & 5 & 6 & 7 & 8 & 9 & 10 & D $\quad \mathrm{S} \quad \mathrm{M}$ & $50 \mathrm{~g}$ & $150 \mathrm{~g}$ & \\
\hline & $\mathrm{N} 1$ & 2 & 3 & 4 & 5 & 6 & 7 & 8 & 9 & 10 & $\begin{array}{|lll|}\mathrm{D} & \mathrm{S} & \mathrm{M} \\
\end{array}$ & & & \\
\hline & $\mathrm{N} 1$ & 2 & 3 & 4 & 5 & 6 & 7 & 8 & 9 & 10 & $\begin{array}{|lll|}\mathrm{D} & \mathrm{S} & \mathrm{M} \\
\end{array}$ & & & \\
\hline & $\mathrm{N} 1$ & 2 & 3 & 4 & 5 & 6 & 7 & 8 & 9 & 10 & $\begin{array}{|lll|}\mathrm{D} & \mathrm{S} & \mathrm{M} \\
\end{array}$ & & & \\
\hline & N 1 & 2 & 3 & 4 & 5 & 6 & 7 & 8 & 9 & 10 & $\begin{array}{lll}\mathrm{D} & \mathrm{S} & \mathrm{M} \\
\end{array}$ & & & \\
\hline & $\mathrm{N} 1$ & 2 & 3 & 4 & 5 & 6 & 7 & 8 & 9 & 10 & D $\quad S \quad M$ & & & \\
\hline & $\mathrm{N} 1$ & 2 & 3 & 4 & 5 & 6 & 7 & 8 & 9 & 10 & $\mathrm{D} \quad \mathrm{S} \quad \mathrm{M}$ & & & \\
\hline
\end{tabular}




\begin{tabular}{|l|l|lllllllll|ll|l|l|l|}
\hline & \multicolumn{3}{|l|}{ Quantas vezes você come? } & Unidade & CODIF. \\
\hline $\begin{array}{l}\text { Com que frequência você usa gordura ou óleo no } \\
\text { preparo de suas refeições? }\end{array}$ & $\mathrm{N}$ & 1 & 2 & 3 & 4 & 5 & 6 & 7 & 8 & 9 & 10 & $\mathrm{D}$ & $\mathrm{S}$ & $\mathrm{M}$ & \\
\hline $\begin{array}{l}\text { Quantas porções de vegetais (verduras e legumes) } \\
\text { você costuma comer, sem incluir batatas ou saladas } \\
\text { de maionese? }\end{array}$ & $\mathrm{N}$ & 1 & 2 & 3 & 4 & 5 & 6 & 7 & 8 & 9 & 10 & $\mathrm{D}$ & $\mathrm{S}$ & $\mathrm{M}$ & \\
\hline $\begin{array}{l}\text { Quantas porções de frutas você costuma comer, } \\
\text { sem incluir sucos de frutas? }\end{array}$ & $\mathrm{N}$ & 1 & 2 & 3 & 4 & 5 & 6 & 7 & 8 & 9 & 10 & $\mathrm{D}$ & $\mathrm{S}$ & $\mathrm{M}$ & \\
\hline
\end{tabular}


PROJETO DE PESQUISA: CORRELAÇÃO ENTRE DIETA E MICROBIOTA: DIVERSIDADE MICROBIANA INTESTINAL EM INDIVÍDUOS COM DIFERENTES HÁBITOS ALIMENTARES.

\section{FORMULÁRIO PARA AVALIAÇÃO ANTROPOMÉTRICA}

Nome:

Participante $\mathrm{N}^{\circ}$ L_L_L Data:

Idade (anos):

1. Peso (kg):

2. Altura (cm):

3. IMC:

4. Classificação:

5. \% de Gordura corporal:

6. \% de Hidratação:

7. $\%$ de Musculatura:

8. \% Massa Óssea :

9. Taxa de Metabolismo Basal:

10. Circunferência da cintura $(\mathrm{cm})$ :

11. Circunferência abdominal $(\mathrm{cm})$ :

12. Circunferência do quadril $(\mathrm{cm})$ :

13. RCQ:

\section{Referência:}

- baixo peso (IMC $<18,5)$,

- eutrofia $(18,5 \leq \mathrm{IMC}<25)$,

- pré-obesidade $(25 \leq \mathrm{IMC}<30)$,

- obesidade (IMC $\geq 30$ ) 
PROJETO DE PESQUISA: CORRELAÇÃO ENTRE DIETA E MICROBIOTA: DIVERSIDADE MICROBIANA INTESTINAL EM INDIVÍDUOS COM DIFERENTES HÁBITOS ALIMENTARES.

\section{FORMULÁRIO PARA AVALIAÇÃO DO ESTILO DE VIDA}

1. Você pratica alguma atividade física? (0) Não Se SIM, qual atividade?

Com que freqüência? vezes/semana.

Quanto tempo gasta praticando atividade física?

(1) Sim.

Quanto tempo gasta praticando atividade fisica? horas.

2. Em média, quanto tempo por dia você gasta assistindo TV ou fica no computador? horas.

3.Você fuma? (0) Não (1) Sim.

Se sim, há quanto tempo? Quantos cigarros fuma por dia?

4. Você costuma consumir bebida alcoólica?

(0) nunca

(1) diariamente

(2) 1 ou menos de uma vez por mês

(3) pelo menos 1 vez por semana

(4) 2 a 4 vezes por mês

(5) 2 a 3 vezes por semana

5. Qual o tipo de bebida você bebe?

(0) Nenhuma (1) cerveja (2) vinhos (3) destilados (cachaça, whisky, vodca, licor) (4) bebidas ice

6. Quantas doses contendo álcool você consome num dia típico quando você está bebendo?
(0) Nenhuma
(1) 1 a 2 doses
(2) 3 a 5 doses
(3) 6 a 8 doses
(4) 10 ou mais 